\title{
GEOLOGIC-HAZARDS
}

\section{MITIGATION IN ALASKA}

A Review of Federal, State, and Local Policies

By R.A. Combellick

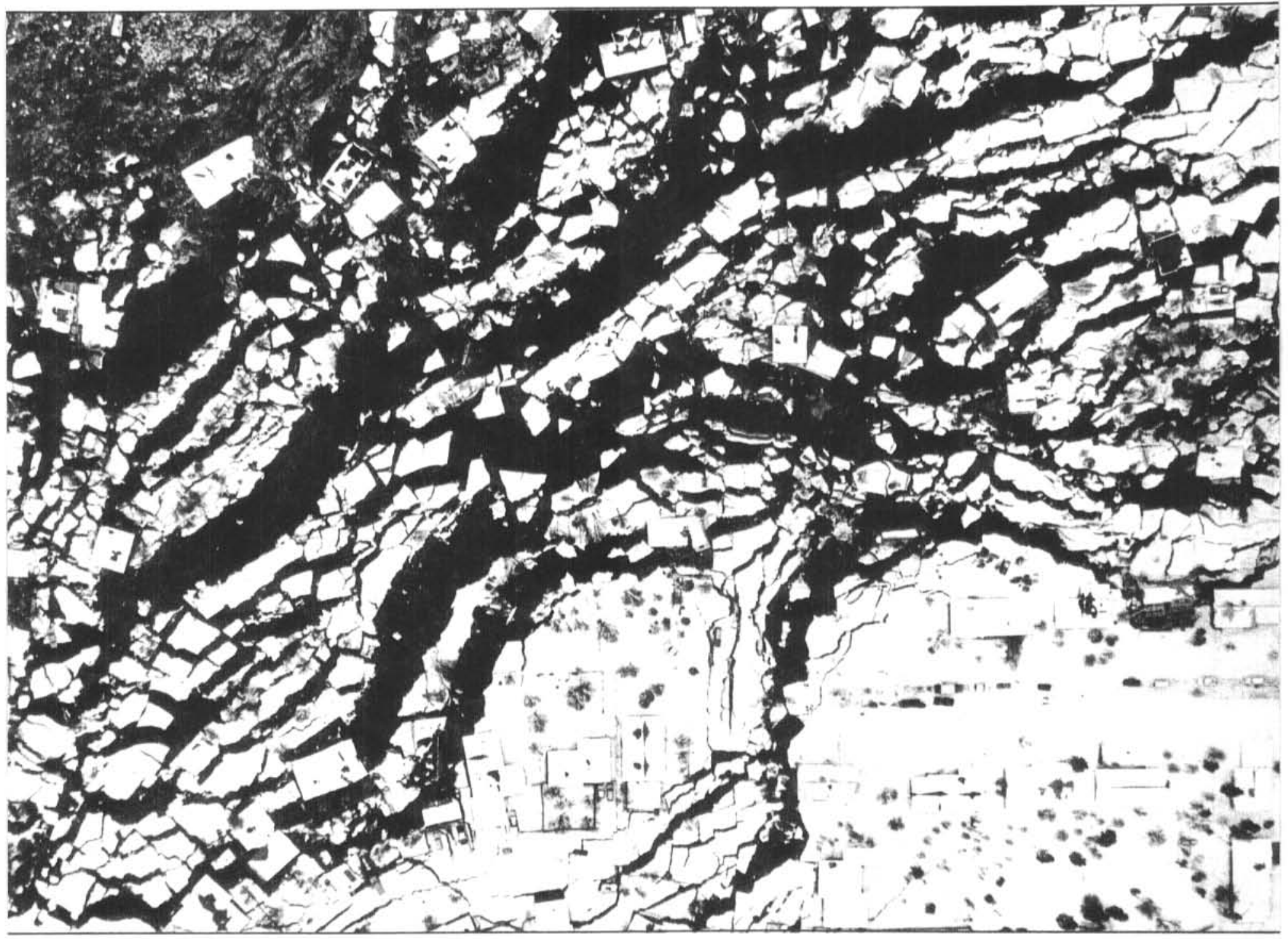

SPECIAL REPORT 35

Published by

STATE OF ALASKA

DEPARTMENT OF NATURAL RESOURCES

DIVISION OF GEOLOGICAL AND GEOPHYSICAL SURVEYS 


\section{GEOLOGIC-HAZARDS MITIGATION IN ALASKA}

A Review of Federal, State, and Local Policies

By R.A. Combellick

Division of Geological \& Geophysical Surveys

Special Report 35

Fairbanks, Alaska 1985 
STATE OF ALASKA

Bill Sheffield, Governor

Esther C. Wunnicke, Commissioner

Department of Natural Resources

Ross G. Schaff, Director and State Geologist

Cover: Aerial view of the Turnagain Heights landslide, southwest Anchorage (top of photograph is north). This landslide, triggered by the Great Alaska Earthquake of March 27,1964, destroyed 75 homes and 130 acres of property. Snow-covered slide blocks, many carrying complete homes, slid laterally as much as 2,000 ft northwest into Knik Arm. U.S. Army photograph, Mohawk Series no. 253 M-64-64, courtesy of Alaska Earthquake Photograph Archive, Stan Blume collection, no. SB-47.

DGGS publications are available at: Alaska National Bank of the North Bldg. (2nd floor), Geist Rd. and University Ave., Fairbanks: $3601 \mathrm{C}$ St. (10th floor), Anchorage; 400 Willoughby Center (4th floor), Juneau; and the State Office Bldg., Ketchikan. Mail orders should be addressed to DGGS, 794 University Ave. (Basement), Fairbanks, AK 99709. Cost $\$ 3$. 


\section{CONTENTS}

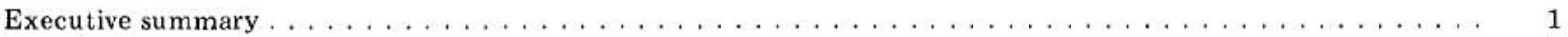

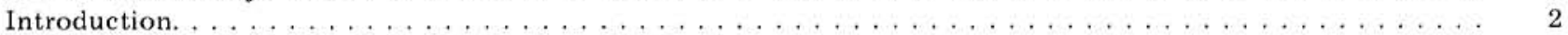

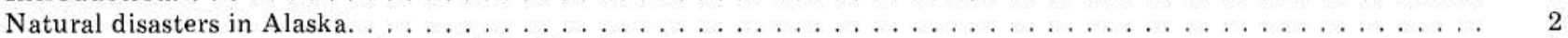

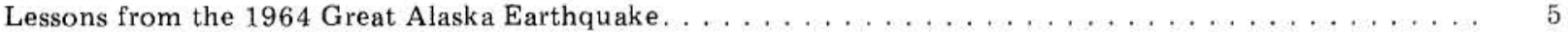

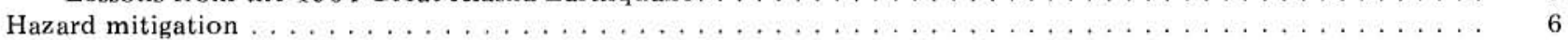

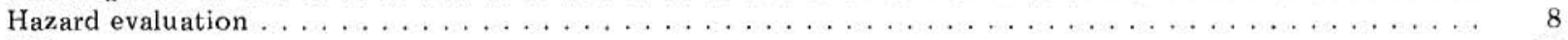

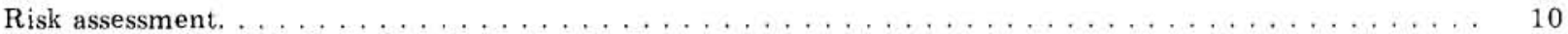

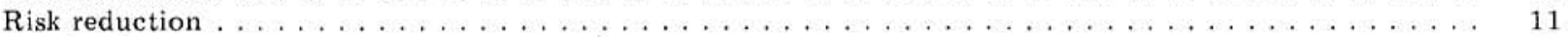

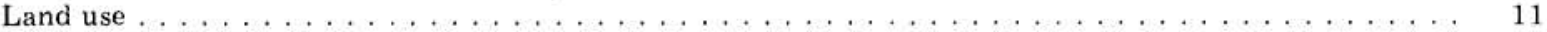

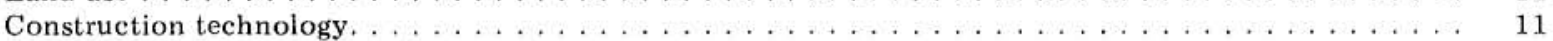

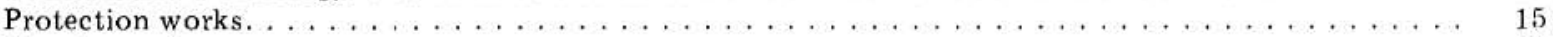

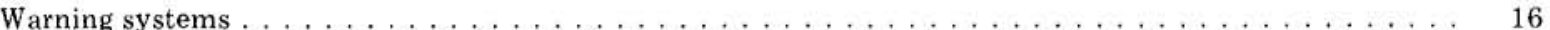

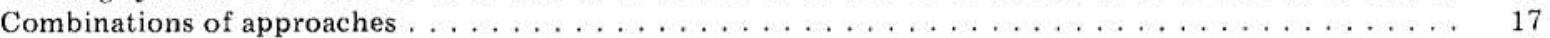

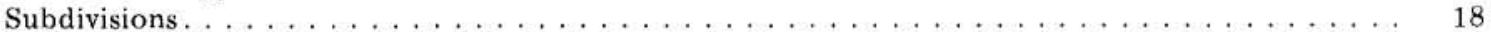

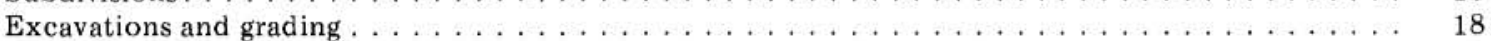

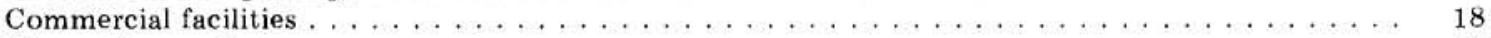

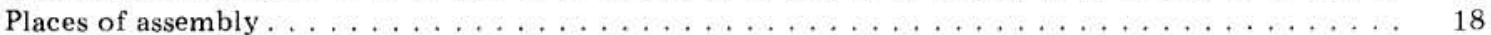

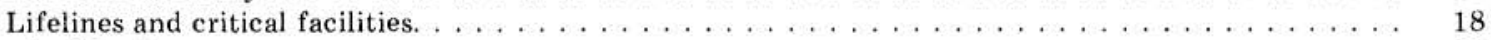

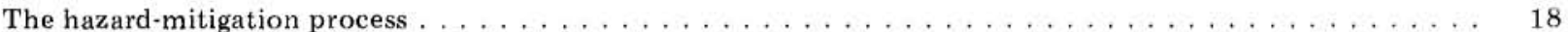

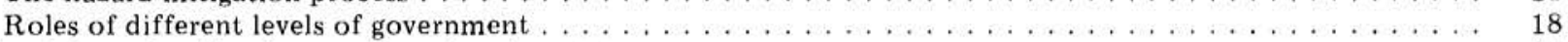

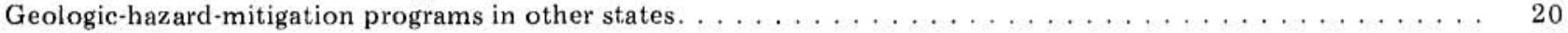

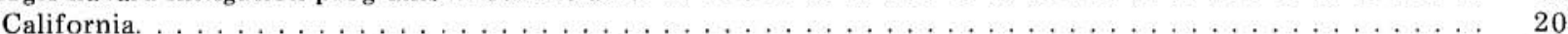

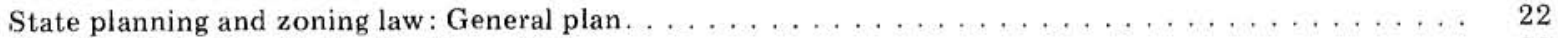

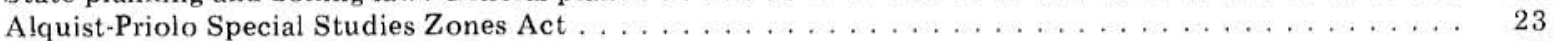

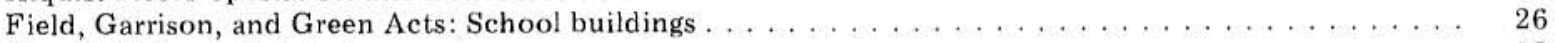

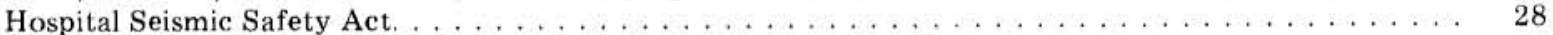

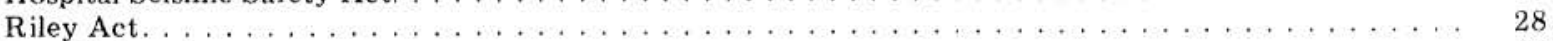

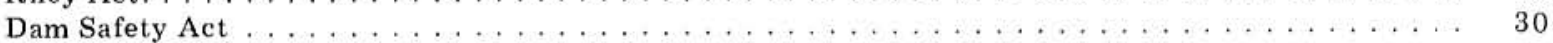

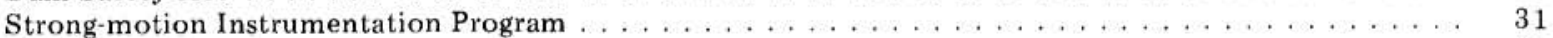

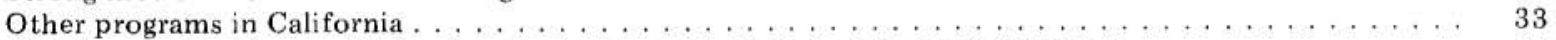

Statutory authority for California agencies engaged in geologic hazard mitigation . . . . . . . . . . 34

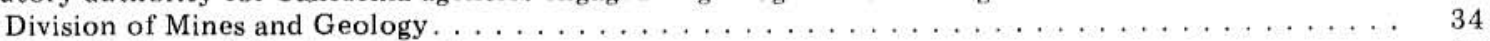

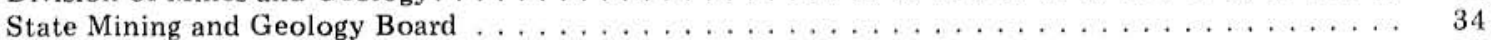

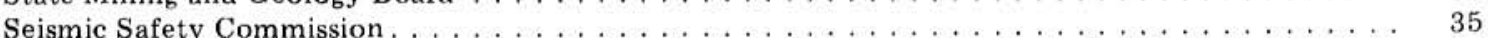

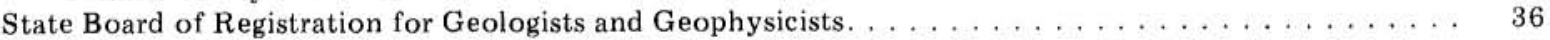

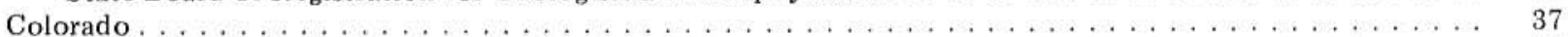

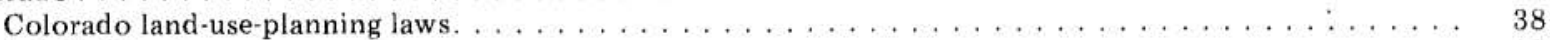

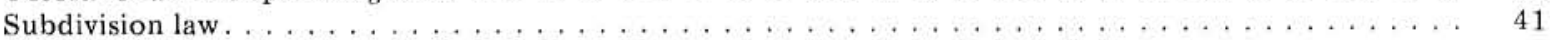

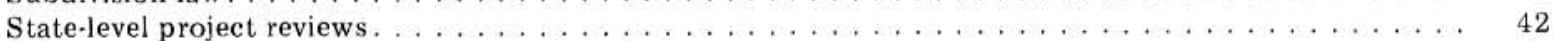

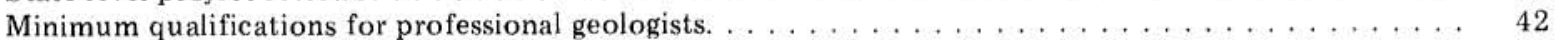

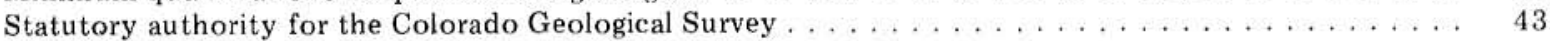

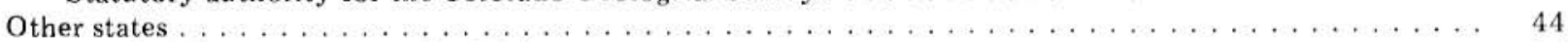

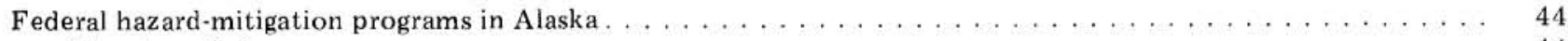

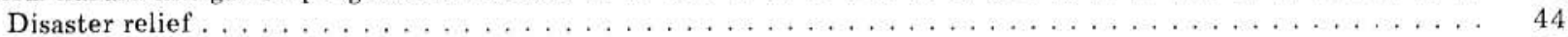

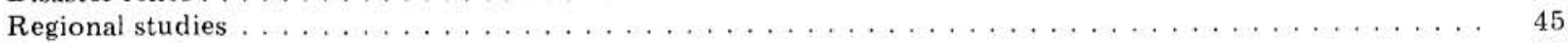

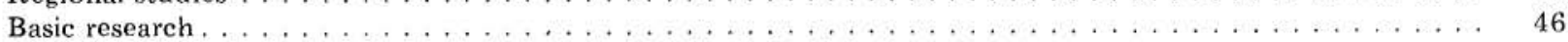

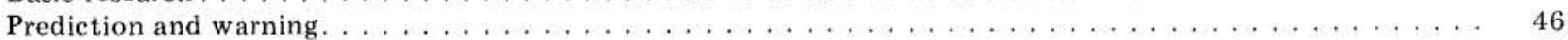

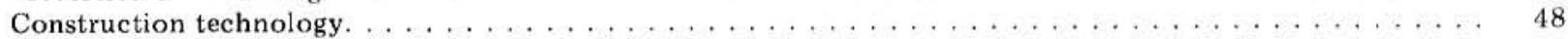

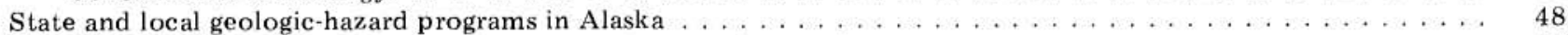

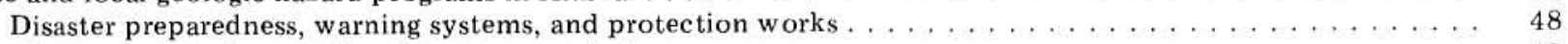

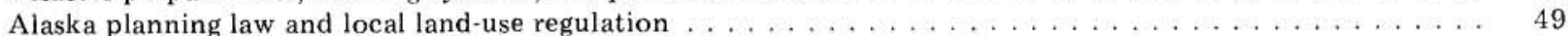

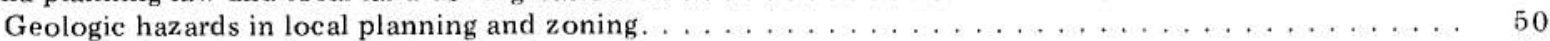

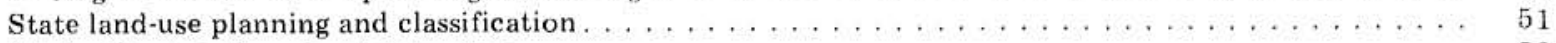

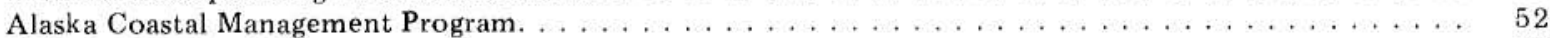

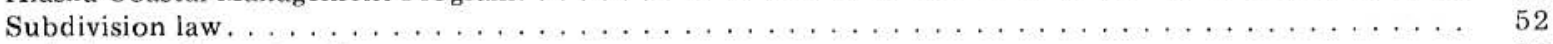

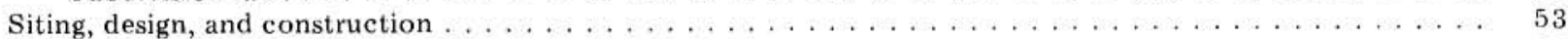

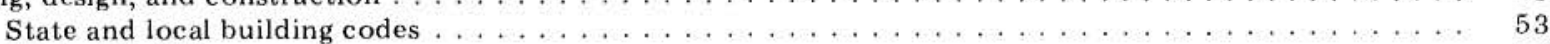

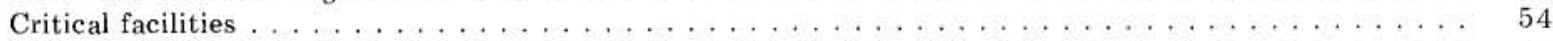

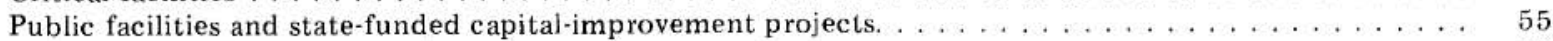

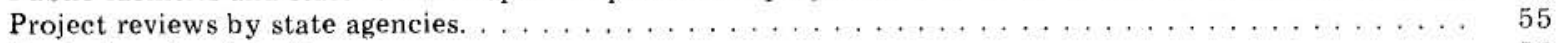

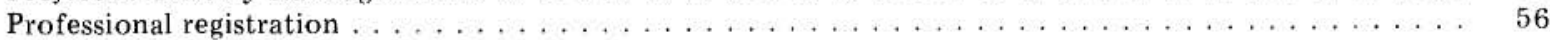




\section{CONTENTS (con.)}

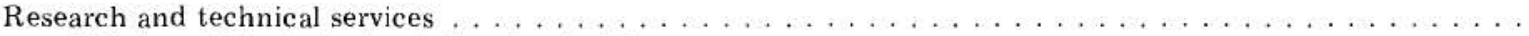

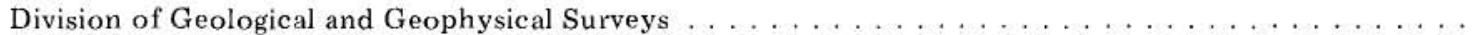

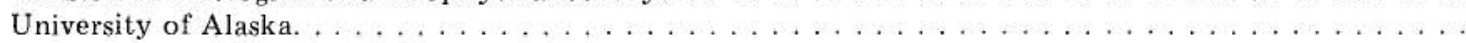

Alaska Council on Science and Technology $\ldots \ldots \ldots \ldots \ldots \ldots \ldots \ldots \ldots$

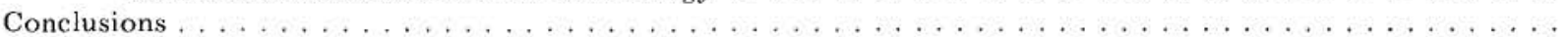

Recommendations from the workshop on evaluation of regional and urban earthquake hazards and risk in

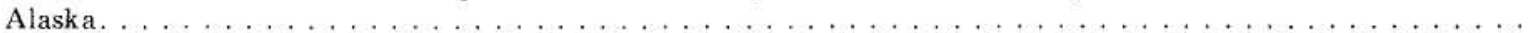

Recommendation 1 - Alaska Natural Hazards Safety Commission . . . . . . . . . . . . . . . .

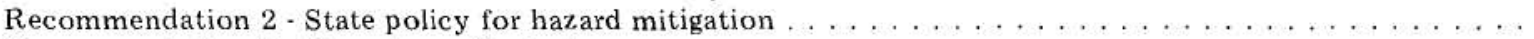

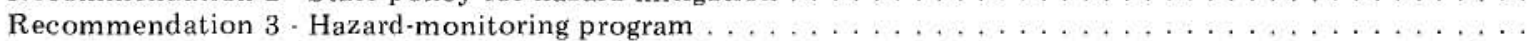

Recommendation 4 - Amendments to the Municipal Code and other statutes to promote local-government action in hazard mitigation . . . . . . . . . . . . . . . . . . . . . . .

Recommendation 5 - State regulation of construction and major alteration of critical facilities. . . . . . . .

Recommendation 6 - Hazard-mitigation requirements for certain capital-construction projects. . . . . . . . .

Recommendation 7 . Conditional availability of disaster-relief funds to promote hazard mitigation. . . . . . .

Recommendation 8 - Improved capabilities for state agencies to provide technical assistance to other

agencies and local governments in hazard mitigation and disaster preparedness $\ldots \ldots \ldots \ldots \ldots$

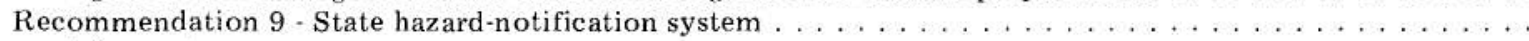

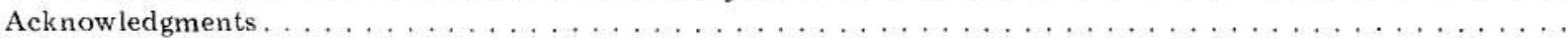

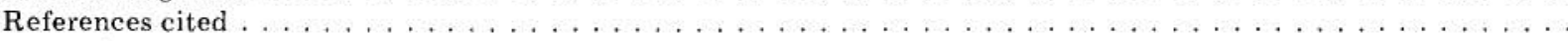

Appendix A - Senate Bill No. 310: An act establishing the Alaska Natural Hazards Safety Commission . . . . . . .

Appendix B - Glossary . . . . . . . . . . . . . . . . . . . . . . . . . .

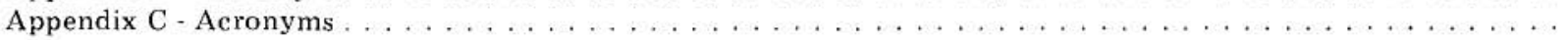

56

\section{FIGURES}

Figure 1. Photograph of downtown Fairbanks during the Chena River flood (1967) . . . . . . . . . 2a-b. Photographs of Lituya Bay before and after the July 9, 1958, earthquake, which triggered

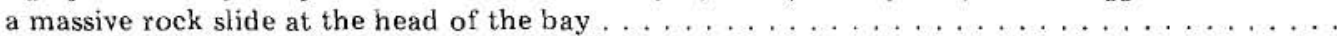

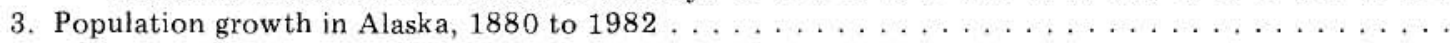

4. Photograph of homes destroyed by a massive landslide in Turnagain Heights subdivision, Anchorage, during the Great Alask a Earthquake of March $27,1964 \ldots \ldots \ldots \ldots \ldots$

5. Photograph of buildings in unstable areas on and near the L Street slide in downtown Anchorage. . .

6. Photograph of the old Valdez townsite taken after a tsunami destroyed port facilities and most

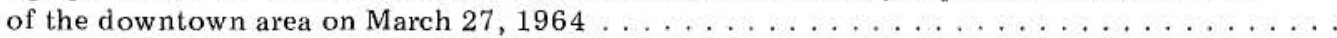

7. Photograph of the new Valdez townsite near Mineral Creek, $3.5 \mathrm{mi}$ northwest of the old

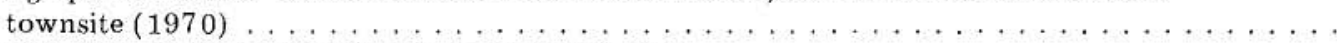

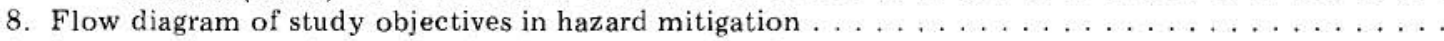

9. Diagram showing the relationship between risk and hazard mitigation $\ldots \ldots \ldots \ldots \ldots$

10. Seismic-zone map from the Uniform Building Code . . . . . . . . . . . . . . . . .

11. Photograph of a floodgate in the Chena Lakes Flood Control Project, about 20 mi east of

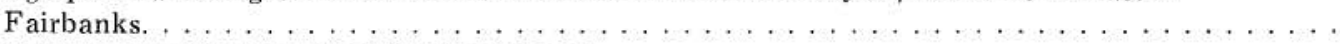

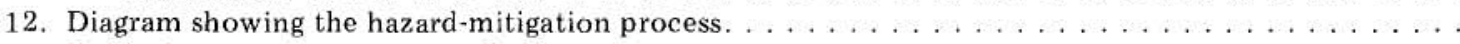

13. Example of a Special Studies Zones map . . . . . . . . . . . . . . . . . . . . .

14. Photograph of John Muir School, Long Beach, California, damaged by the March 10, 1933,

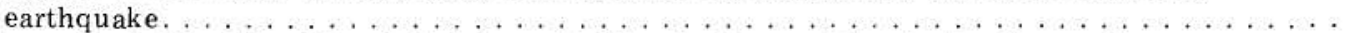

15. Photograph of Olive View Hospital, Sylmar, California, damaged by the San Fernando

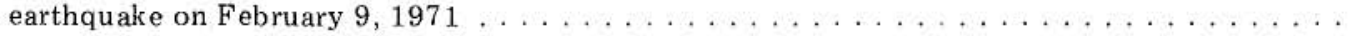

16. Diagram showing functional relationships between the Seismic Safety Commission and other organizations and activities in California $\ldots \ldots \ldots \ldots \ldots \ldots \ldots \ldots \ldots \ldots \ldots \ldots \ldots \ldots$

17. Map showing areas of Alaska for which surficial-geologic maps were available in 1983 at scales useful for land-use planning. . . . . . . . . . . . . . . .

\section{TABLES}

Table 1. Significant geologic hazards in Alaska . . . . . . . . . . . . . . . . . . .

2. Suggested roles of federal, state, and local governments in hazard mitigation and disaster

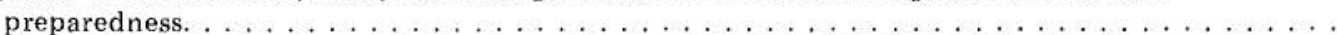

3. Summary of responsibilities and functions under the Alquist-Priolo Special Studies Zones Act. . . .

4. Functions of local and state agencies regarding geologic-hazard areas under Colorado House bill

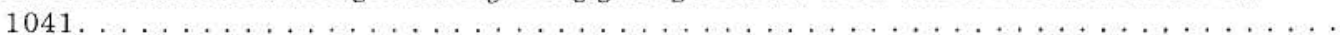




\title{
GEOLOGIC-HAZARDS MITIGATION IN ALASKA
}

\section{A Review of Federal, State, and Local Policies}

\author{
By \\ R.A. Combellick ${ }^{1}$
}

\section{EXECUTIVE SUMMARY}

Earthquakes and volcanic eruptions occur frequently in Alaska. Because the climate is dynamic, topographic variation is extreme, and thousands of miles of coastline are exposed to the open ocean, Alaska will continue to to be affected by these and other natural phenomena such as landslides, snow avalanches, floods, tsunamis, and many localized or chronic events that may be as costly over the long term as major events. Because development is rapidly expanding into areas where geologic hazards once had little effect, the same events may now cause major property damage.

Technology is available to identify natural hazards, determine their probable severity, and reduce their potential effects on people and property. On the basis of this review of national and state policies, 10 issues were identified in which possible improvements could substantially benefit public safety from natural hazards in Alaska:

1. Policy guidance and coordination of state and local hazard-mitigation programs.

2. Availability of basic technical information on hazards for land-use planning and construction.

3. Continuation of many federally funded hazards studies in Alaska that are being terminated or substantially reduced.

4. Incentives and guidelines to consider geologic hazards in local plans and ordinances.

5. Hazard mitigation in siting, design, and construction of critical facilities.

6. Hazard mitigation in siting, design, and construction of many state-funded public facilities.

7. The relationship between hazard mitigation and eligibility for disaster-relief funds.

8. Capability of state agencies to provide adequate technical services, assistance, and project reviews on geologic hazards for other agencies and local governments.

9. Standards of experience and education for geologists who prepare reports required by state or local laws for siting or designing facilities.

${ }^{1}$ Alaska Division of Geological and Geophysical Surveys, 794 University Ave, (Basement), Fairbanks, Alaska 99709.
10. State capability to issue formal state notices of serious geologic hazards and coordinate the response by state and local agencies.

A comprehensive review of existing programs in California, Colorado, and the federal government sug. gests that some common attributes are responsible for the success and public acceptance of many hazardmitigation programs. These attributes include central policy guidance and coordination; availability of current technical information; incentives and guidelines to consider geologic hazards in local ordinances; immunization of local governments from hazards-related liability under certain circumstances; availability of guidelines and state assistance to recognize and mitigate hazards at the local level; centralized review of design and construction plans for critical and public facilities; appropriate standards for design and construction of facilities that are subject to review for hazard safety; adequate training and experience for reviewers; incentives for hazard mitigation as part of disaster-relief programs; and the ability of programs to be self-supporting through special revenue programs.

The 10 policy issues listed above were discussed by participants at a workshop entitled 'Evaluation of regional and urban earthquake hazards and risk in Alaska.' The workshop was organized by the U.S. Geological Survey and took place September 5-7, 1985, in Anchorage. Participants included seismologists, geologists, engineers, planners, emergency coordinators, policymakers, and educators that represented levels of government, the private sector, and academia. The participants unanimously adopted nine recommendations for improvements in state policy:

1. Establishment of an Alaska Natural Hazards Safety Commission to provide policy guidance for the Governor and Legislature and to help coordinate agency programs in natural hazards.

2. Development of state policies for hazard mitigation in Alaska that establish long-term commitments and goals.

3. Establishment of a hazard-monitoring program that ensures availability of basic data needed to evaluate hazards.

4. Amendments to the municipal code and other 
statutes to promote local-government action in hazard mitigation.

5. State regulation of construction and major alterations of critical facilities to ensure that they are reasonably protected from natural disasters.

6. Establishment of hazard-mitigation requirements for certain capital-construction projects financed by the State.

7. Establishment of incentives or requirements for local governments to implement hazard-mitigation measures as a condition for receiving disaster-relief funds.

8. Improvement in capabilities of state agencies to participate in reviews and to assist other agencies and local governments in problems that relate to hazard mitigation and disaster preparedness.

9. Establishment of a state hazard-notification system to supplement that of the U.S. Geological Survey and help coordinate responses by state and local agencies.

\section{INTRODUCTION}

Many processes that are responsible for Alaska's scenic beauty and abundant resources are also responsible for the wide variety of physical conditions and natural hazards that challenge the human presence. Earthquakes and volcanoes are as active in Alaska as anywhere else in the world, the climate is severe, topographic variation is extreme, and thousands of miles of coastline are exposed to the open ocean. Thus, Alaska is subject to major earthquakes, volcanic eruptions, landslides, snow avalanches, floods, tsunamis, and many local or chronic hazards, such as permafrost, that can be costly for property owners over a long period of time. Effective mitigation efforts have greatly reduced these costs in other states.

Although the number of major natural events in the recent past is high, few events have significantly affected the general public because of Alaska's relatively sparse population and vast, thinly inhabited areas. Major events will continue to occur intermittently as in the recent geologic past, and with increasing development, the probability will increase that people, businesses, property, and critical facilities will be affected.

Experience in other states demonstrates that local ordinances are among the most effective means of mitigating natural hazards. State governments generally provide guidelines, technical information, and the requirement or incentives for local adoption of riskreduction measures. All municipalities in Alaska have zoning authority that can incorporate hazard-mitigation measures. Flood-plain-management ordinances have been adopted in at least 20 cities and boroughs. Other hazards have been only generally addressed. A few local governments have recently begun to independently act on specific issues of local concern. Most major municipalities have adopted the Uniform Building Code published in 1982 by the International Conference of Building Officials (ICBO). Although this code provides detailed requirements for earthquake-resistant design and construction, it does not provide comprehensive construction and siting requirements for other hazards.

The purposes of this report are fourfold: 1) review geologic-hazard issues in Alaska from an historical perspective; 2) discuss various approaches to hazard mitigation; 3) evaluate hazard-mitigation programs in other states (their strengths, weaknesses, and applicability in Alaska); and 4) review existing state, federal, and local programs dealing with hazards in Alaska. This report also includes a summary of policy recom. mendations developed in September 1985 during an interagency workshop on earthquake hazards in Alaska. Because major programs of disaster preparedness and response already exist and operate under the Division of Emergency Services and local agencies, these activities are not discussed in detail. This report focuses primarily on activities that reduce the likelihood of injury or damage from natural hazards. Greater emphasis on knowledge of the hazards, public awareness, and effective mitigation measures will reduce vulnerability to hazards and consequently reduce dependence on postdisaster response and relief.

\section{NATURAL DISASTERS IN ALASKA}

From 1964 to 1981 , there were seven presidential declarations of disaster in Alaska, an average of one every $2.5 \mathrm{yr}$. These natural disasters included one major earthquake, three floods, one heavy rain and landslide, one severe freeze, and a major fire during a severe freeze. Although a total of about $\$ 76$ million in federal aid was provided, it was far short of the total estimated damages. For example, of the $\$ 350$ million estimated damages that resulted from the 1964 Great Alaska Earthquake in 1964 , about $\$ 56$ million in federal aid was provided. Except for restoration work performed directly by the U.S. Army Corps of Engineers, the remaining burden fell on state and local governments, private businesses, and individuals. Following the Chena River flood in Fairbanks in August 1967 (fig. 1), which resulted in damages that totalled about $\$ 84$ million (Péwé, 1982), the federal government provided $\$ 7.3$ million in direct financial aid (Federal Emergency Management Agency, 1982).

In addition to disaster declarations by the President, for which federal relief funds are available, the Governor of Alaska is authorized to make disaster declarations for which state relief funds are provided, generally through the Alaska Division of Emergency Services (ADES). State funds may supplement federal-relief funds for presidentially declared disasters, but more often are used to provide relief after events that are not declared disasters at the federal level. From January 1978 to February 1982, no disasters were declared in Alaska by 


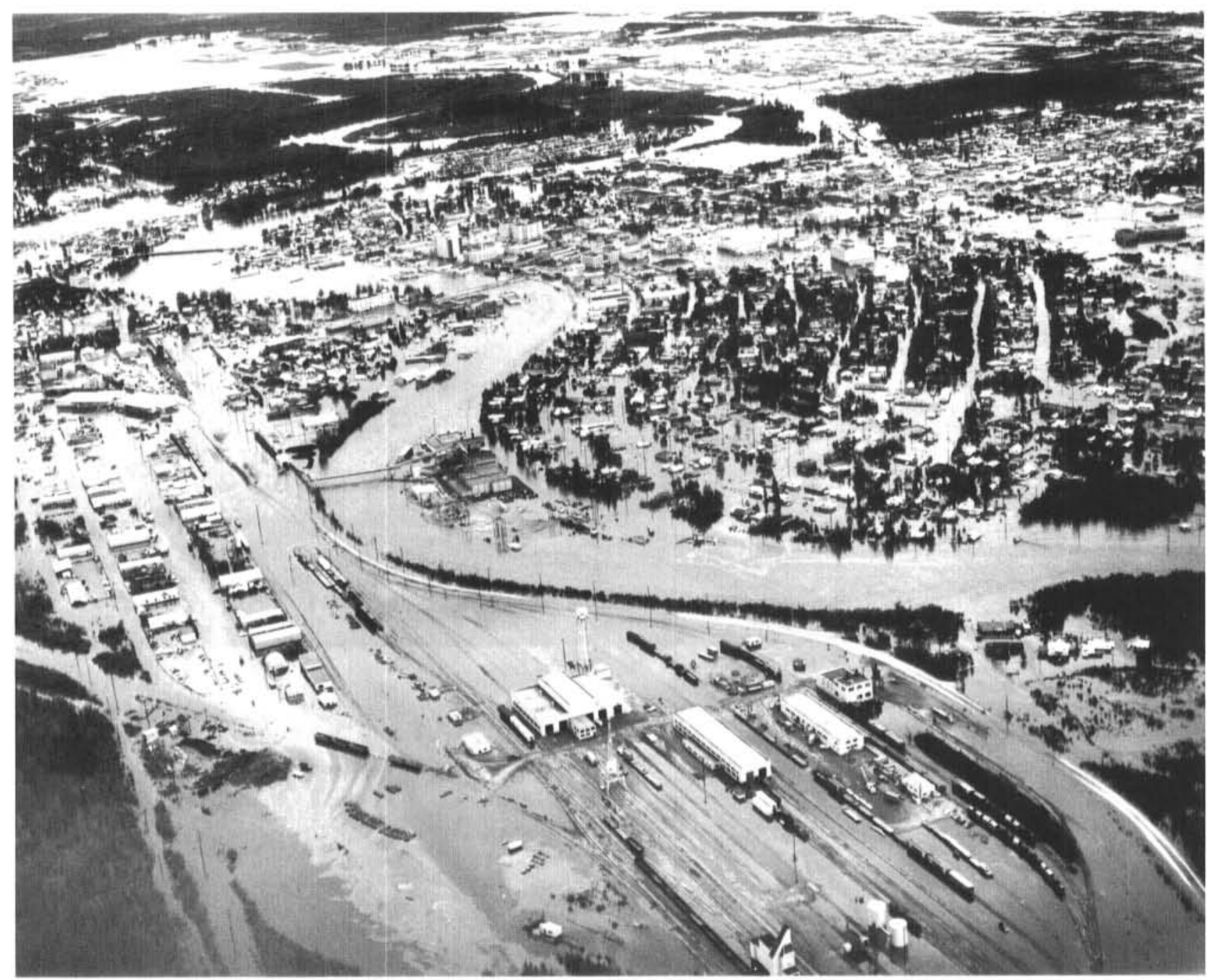

Figure 1. Aerial view of downtown Fairbanks, Alaska, during the Chena River flood. Photograph by U.S. Bureau of Land Management, August 16, 1967.

the federal government, but the Governor made 14 disaster declarations, an average of 2.5 every year. Relief funds authorized by the Governor ranged from $\$ 14,000$ to $\$ 505,000$ per disaster and totalled slightly more than $\$ 2$ million for the 4-yr period. These figures are not necessarily all the funds expended; they do not reflect all expenditures through agencies outside ADES, but provide an estimate of the magnitude of state expenditures used to respond to natural disasters.

State expenditures for disaster relief are likely to increase as development extends into areas once considered remote and marginally suitable for development. Because many major natural events have occurred in remote areas where property damage was small, they are not commonly recognized as manifestations of continuing processes that will eventually affect developed areas. In 1912, a major volcanic eruption near Mt. Katmai was about 24 times larger than the 1980 eruptions of Mount St. Helens in terms of volume of magma ejected (Decker and Decker, 1981). A giant landslideinduced seiche occurred in Lituya Bay during an earthquake in 1958. The seiche stripped all vegetation to an elevation of $1,740 \mathrm{ft}$ on the mountain opposite the slide and resulted in two deaths, even though Lituya Bay is only seasonally inhabited by a few people (figs. $2 a, b)$. In 1946, a 100-ft-high tsunami hit Unimak Island, destroyed the lighthouse at Scotch Cap, and killed five people; in addition, it killed dozens of people and inflicted extensive property damage elsewhere on the Pacific coast. In 1899, an earthquake of Richter magnitude 8.4 occurred near Yakutat Bay that elevated the coastline as much as $49 \mathrm{ft}$ (Tarr and Martin, 1912).

Although many of these events are unusually devastating, they are not unique; they are the episodic results of ongoing natural processes that will continue to produce similar destruction in Alaska. For example, at least 40 of the more than 80 volcanoes in the Aleutian Islands and Wrangell Mountains have erupted at least 


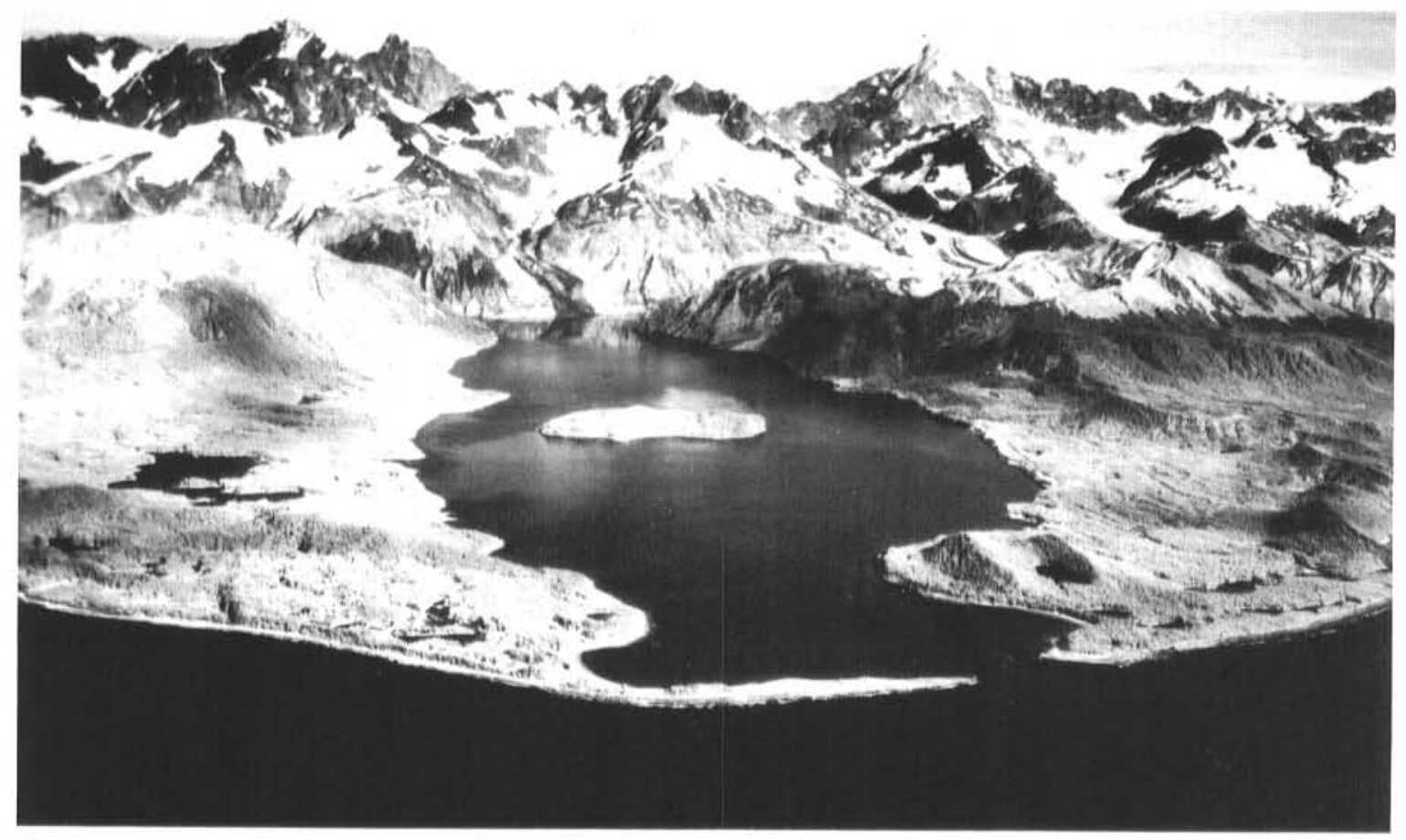

a

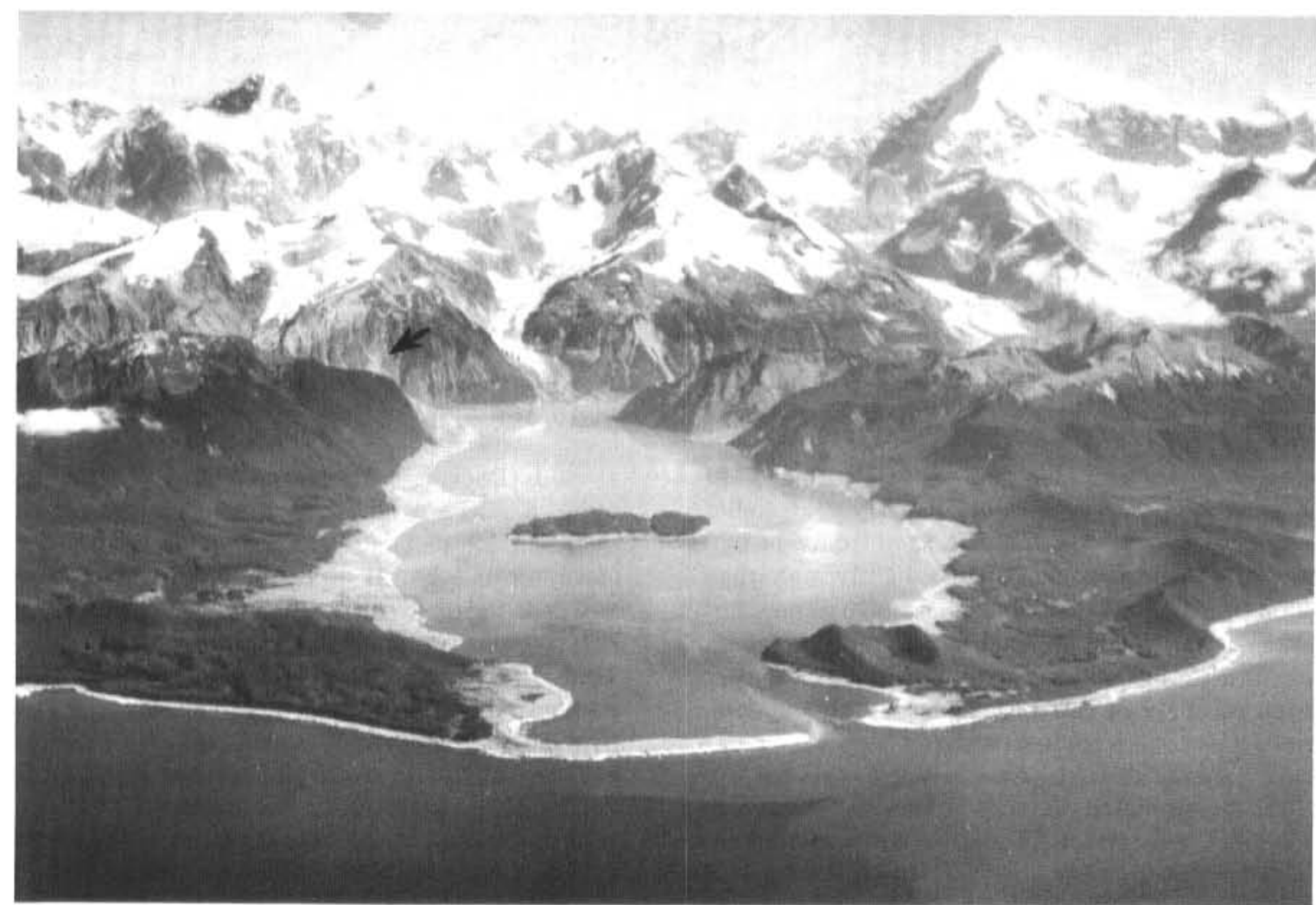

b

Figure 2. (a) View of Lituya Bay, Alaska, September 16, 1954. (b) The same area after the July 9, 1958, earthquake (Richter magnitude 7.9) that triggered a massive rock slide at the head of the bay (arrow). The resultant wave stripped vegetation to an elevation of $1740 \mathrm{ft}$ on the hillside opposite the slide (August 9, 1958). Photographs by D.J. Miller, U.S. Geological Survey. 
once during the past $200 \mathrm{yr}$ (Miller, 1976). Four giant waves have occurred in Lituya Bay since the mid-1800s (Miller, 1960); at least six tsunamis over $30 \mathrm{ft}$ high have struck the Alaska coast during the last $100 \mathrm{yr}$ (Cox and Pararas-Carayannis, 1976), and 15 great earthquakes $(\mathrm{M}>7.8)$ have occurred in Alaska since 1899 (Meyers, 1976), an average of one every $5.5 \mathrm{yr}$.

The population of Alaska increased dramatically in the late 1960 s and early 1970 s and continues to grow at a steady rate (fig. 3 ). Undoubtedly, human exposure to natural hazards will increase substantially as the population grows and occupies larger areas. More events will be declared disasters at the state and federal levels because they affect more people. A corresponding increase in casualties and expenditure of public funds for disaster relief can be expected unless continued precautions are taken to reduce vulnerability to hazards.

Recent changes in federal policy add to the burden of disaster recovery on state and local governments and individuals, as the people in Fort Wayne, Indiana, discovered after their spring 1982 flood. Because of recent policy changes, federal grants to local governments for repair of public facilities are limited to 75 percent of the total cost of damages; state and local governments are responsible for the remainder. Also, federal disaster-relief loans to individuals and businesses are no longer available at low interest rates (Federal Emergency Management Agency, oral commun., 1983). Loans issued at less than the conventional interest rate are only available to applicants who cannot qualify at the conventional rate. Thus, many people in Fort Wayne faced interest rates of about 16 percent on their disaster loans, as opposed to the 3 percent charged Alaskans in 1964 after the Great Alaska Earthquake.

\section{LESSONS FROM THE 1964 GREAT ALASKA EARTHQUAKE}

The Great Alaska Earthquake of March 27, 1964 (Good Friday), provided an unprecedented opportunity to assess several conditions and effects: 1) the soundness of construction methods; 2 ) the effects of state and local land-use practices under conditions of severe ground shaking; 3 ) the effectiveness of disaster response; 4) the approaches to postearthquake recovery; and 5) the subsequent impact on land-use regulation and construction practices. Unfortunately, many lessons from this event have not been taken seriously. Because of the increased population and accelerated construction in high-risk areas, Alaskans are more vulnerable now than they were in 1964. Selkregg and others (1970; 1984) reviewed planning and regulatory factors that relate to the 1964 earthquake and its aftermath. Their reviews, summarized below, underscore the desirability to assess hazard-mitigation measures in Alaska.

When the 1964 Great Alaska earthquake occurred, there was no state-development plan and there were very

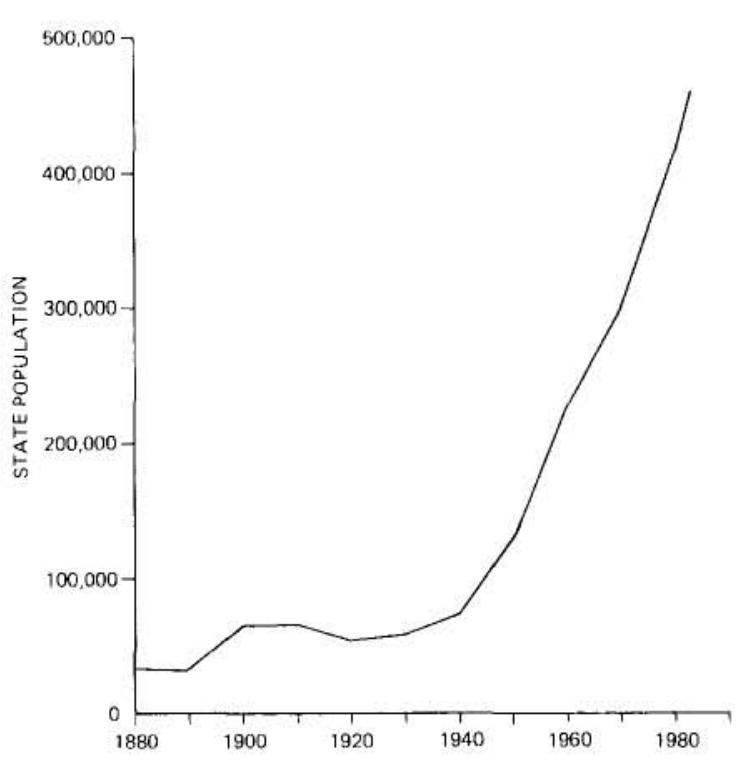

Figure 3. Population growth in Alaska, 1880 to 1982. Data from Rollins, 1978, and Alaska Department of Labor, 1983.

few controls on land use and construction in Alaska. Very little state assistance was available to local com. munities to prepare their own comprehensive development plans and implement zoning controls. In addition, few state or local efforts had been made to collect basic data on geologic hazards in developing areas. Consequently, very little had been done to mitigate the effects of earthquakes or other geologic hazards. This situation not only accounted for much of the damage that occurred, but made it nearly impossible to make intelligent, defensible decisions for improvements during reconstruction. Reconstruction practices varied widely throughout the affected region, and many hard-hit areas were allowed to redevelop to preearthquake standards and conditions.

Anchorage was the only city in the affected region that adopted the ICBO Uniform Building Code before 1964 , and many large buildings constructed according to that code withstood the severe shaking. A few buildings moved more than $11 \mathrm{ft}$ without substantial damage except to utilities. However, local development plans and zoning ordinances did not consider potential hazards, and some heavily developed residential and business areas were affected by major destructive ground displacements. One of the few reports that contained geologic-hazards information on the Anchorage area before 1964 identified areas of poor foundation materials and slope instability (Miller and Dobrovolny, 1959). Although the report was available $4 \mathrm{yr}$ before the earthquake, it was apparently not used in local planning. 
Many unstable areas identified in the report failed during the earthquake, which resulted in millions of dollars in damage to homes, businesses, and utilities.

Soon after the earthquake, several groups began to technically evaluate the affected area. The groups included an Engineering Geology Evaluation Group established by the Alaska State Housing Authority (ASHA); a federal Scientific and Engineering Task Force appointed by a special presidential commission; a panel of architects and engineers also appointed by the commission; and the U.S. Army Corps of Engineers. High-risk areas were identified, based on unstable soils and proximity to steep slopes. Recommendations were made to prohibit or severely restrict construction in high-risk areas or to limit high-risk areas to offstreet parking, parks, and other low-density purposes. A strong plea was made to improve planning and zoning and adopt and enforce building codes. Many local people objected to the recommendations because they thought the recommendations would further disrupt an economy already seriously impacted by the earthquake, despite arguments that the project would provide much-needed renovation in parts of the Anchorage business district and the chance to implement sound redevelopment plans.

Pressures were great to rebuild Anchorage to its preearthquake status as quickly as possible. Ultimately, the recommended urban-renewal projects, which originally included all areas identified as high risk, were reduced to only those areas that were directly damaged by the earthquake; adjacent unstable zones were excluded. The Corps of Engineers extensively studied the Turnagain Heights landslide area where many homes and utilities were destroyed (fig. 4). They reported that the slide material would continue to be subject to 'substantial differential movements' and 'locally large distortions during future earthquakes.' Accordingly, they concluded that construction of any type should be prohibited on the slide material. Although ASHA originally recognized a high-risk area that extended far inland from the slide scarp, its final redevelopment plan for Turnagain Heights reflected the strong public resistance to urban renewal and limited the proposed project to the area on the seaward side of the scarp that had failed during the earthquake ${ }^{2}$. The ASHA adopted the Corps of Engineers' recommendations and recommended that the high-risk area be redeveloped for park and recreation purposes only. However, the Anchorage City Council decided not to adopt the plan and began to accept applications for building permits in the slide area.

Similarly, the L Street slide area in downtown Anchorage was designated as high risk and recommended

\footnotetext{
${ }^{2}$ Subsequent engineering analyses in unaffected areas inland from the Turnagain Heights landslide demonstrated that the sediments responsible for failure (Bootlegger Cove Formation) have a safety factor of only 0.85 (Seed and Wilson, 1966). which indicates an unsafe condition because the material is not strong enough to withstand anticipated loads.
}

for limited single-family residential construction and recreational open space. The council again decided not to adopt the recommendations. Permits were issued to rebuild existing buildings and erect new structures on the slide and in the adjacent high-risk area. Large, high-occupancy buildings continue to be constructed on and near the slide (fig. 5).

The approach to postearthquake reconstruction in Valdez contrasted markedly with Anchorage. Valdez and its marine facilities were seriously damaged by a tsunami and submarine slide caused by the earthquake (fig. 6). Because of earthquake hazards posed by rebuilding Valdez in the same location, the residents voted to move the entire town to a new location near Mineral Creek (fig. 7). The new site is naturally protected against tsunamis, and the soil is stable. The move, endorsed by the federal task force, paved the way for major assistance by the U.S. Office of Emergency Preparedness and Corps of Engineers. A new mayor and city council were elected to carry out the move, and an aggressive new planning and zoning commission was appointed. The Uniform Building Code was adopted, a comprehensive redevelopment plan was developed by a private contractor, and the entire town was relocated by the fall of 1967.

A major improvement in state disaster preparedness was made when a comprehensive disaster act was passed in 1977. Under this act, the newly created Division of Emergency Services (DES) initiated major disasterpreparedness plans and programs to improve the ability of state and local agencies to respond to disasters. This improvement in response capability is not matched by a complementary program of predisaster measures for proper land-use and construction practices to reduce the likelihood of injury or property damage.

In completing its eight-volume analysis of the 1964 earthquake and its aftermath, the National Research Council (1973) observed that if the earthquake had occurred in a more densely populated area during work and school hours (the event was at 5:36 p.m.), it could have resulted in 50 times as many deaths and 60 times as much property damage. The council concluded that improved hazard mitigation is possible only through research and meaningful regulation, which serve as a basis for improved design, construction, and land-use decisions, and better containment of disasters. Both require improved knowledge of the hazards, adequate warnings, and dependable response and recovery plans.

\section{HAZARD MITIGATION}

Advance planning and preparation are essential to prevent or minimize adverse effects from natural hazards and respond to disasters when they occur. The first step in this effort is to learn as much as possible about natural processes and their potential effects. The second step is to use that information to develop measures that reduce the likelihood of injury and damage to persons 


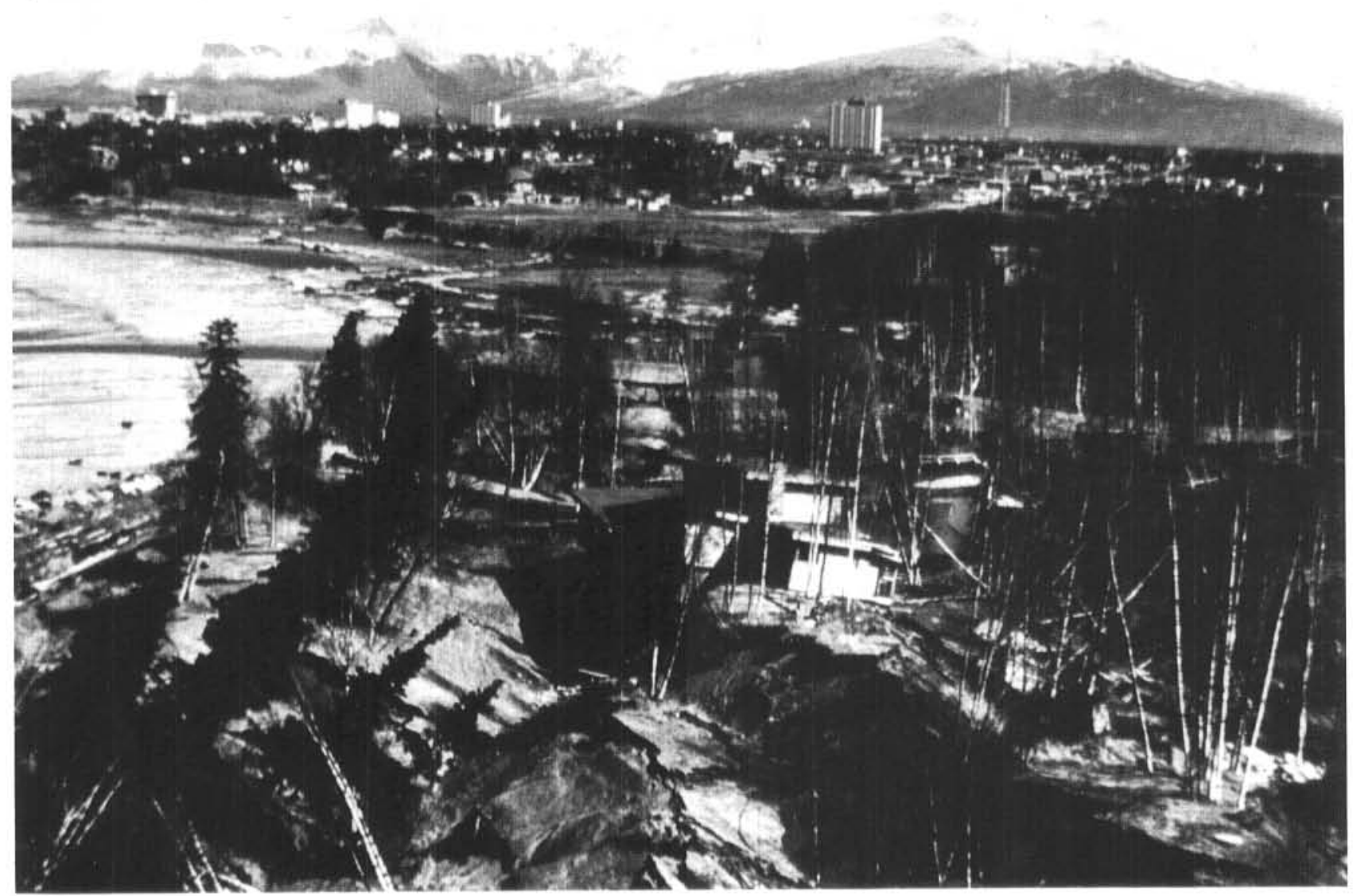

Figure 4. During the Great Alaska Earthquake of March 27, 1964, homes were destroyed by a massive landslide in Turnagain Heights subdivision, Anchorage. U.S. Army Corps of Engineers photograph, courtesy of Alaska Earthquake Photograph Archives (archive no. TRN-35),

and property at risk from the hazard. The third step is to develop the means to quickly respond to a disaster, restore public order, and remove the threat of further injury or damage. Hazard mitigation encompasses activities that reduce the likelihood of property damage or personal injury from a natural event. Disaster preparedness acknowledges that, particularly with major events, there will be property damage and personal injury that cannot be prevented through hazard mitigation. Therefore, disaster preparedness creates mechanisms to respond to the disaster, enables an orderly recovery, and distributes financial losses. Response preparation normally includes plans, facilities, and programs for evacuation, search and rescue, communication, shelter, food, police protection, debris removal, rapidly deployable protection works (such as sand-bag levees), and restoration of lifelines and critical facilities. Hazard insurance and disaster-relief funds (the latter supported by taxes) are the most common means of distributing financial losses. In this report, relief funds and insurance are considered functions of disaster preparedness rather than mitigation because they do not reduce the overall cost of a disaster; they simply distribute those costs among taxpayers and insurance buyers. Although hazard insurance and disaster relief cannot substitute for adequate safety measures, they can be effective tools for mitigation if they include the proper incentives, such as reduced insurance rates for taking specified loss-reduction measures or requirements for taking such measures as a condition of eligibility. Disaster response puts disaster-preparedness plans and other postdisaster activities into effect to restore order and facilitate recovery. This report emphasizes hazard mitigation and does not discuss disaster preparedness and response in detail except where improvements can be made to promote mitigation.

The first two steps in the hazard-mitigation process, hazard evaluation and risk assessment, are prerequisites to the third step, risk reduction. Reliable information on natural processes and their associated risks is essential to determine appropriate risk-reduction measures. Inadequate information can result not only in inadequate or misguided measures, but can contribute to overdesign and overregulation. 


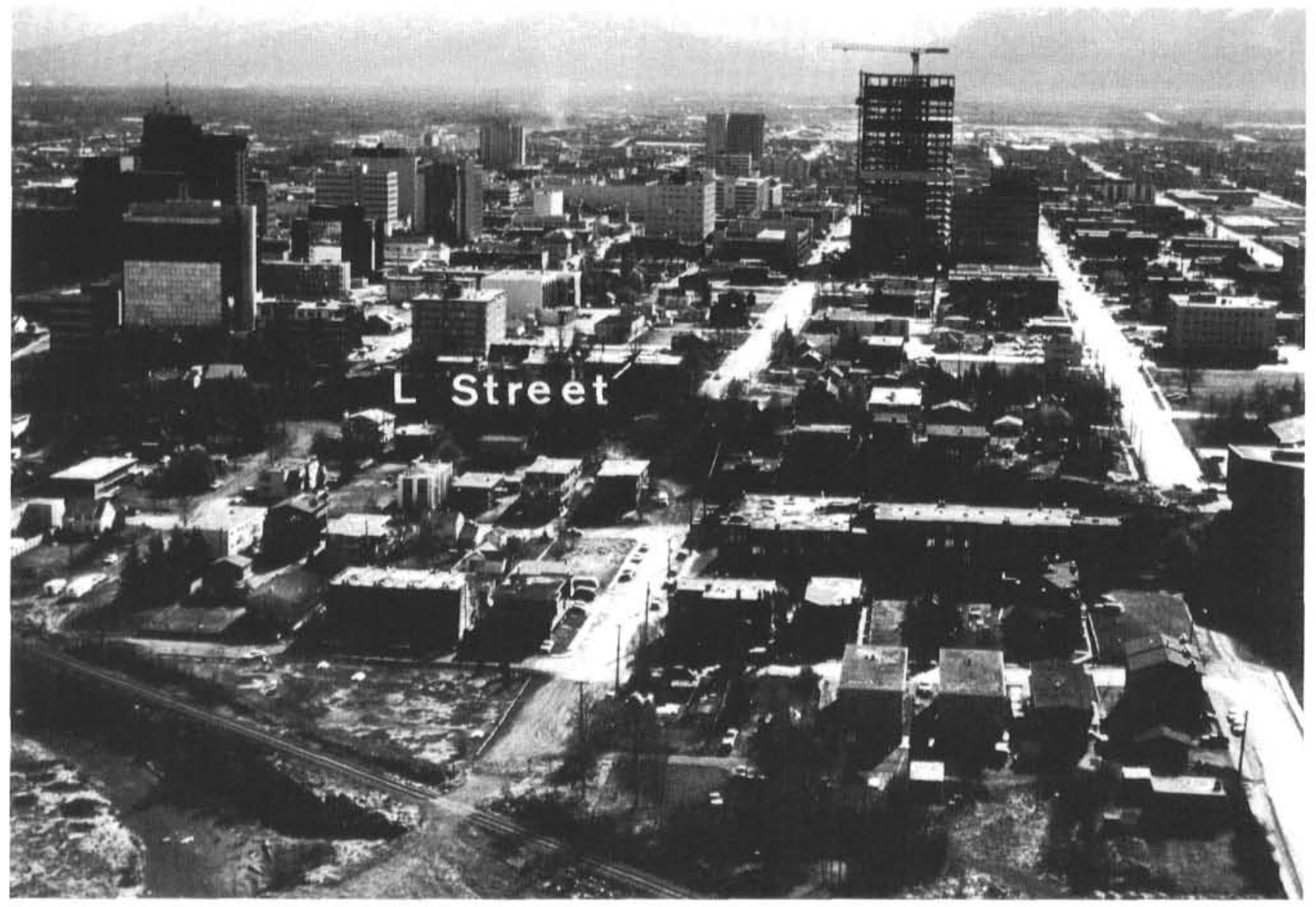

Figure 5. Buildings in unstable areas on and near the L Street slide in downtown Anchorage. This slide (and others) was triggered by the earthquake that occurred March 27, 1964. Photograph by R.A. Combellick, May $22,1982$.

\section{HAZARD EVALUATION}

The objective of hazard evaluation is to produce five kinds of information:

1. Descriptions of natural processes and controlling factors that relate to the hazard.

2. Location and extent of potentially affected areas.

3. Probability and frequency of occurrence.

4. Probable severity (for example, magnitude, intensity, and duration).

5. Expected physical effects.

Understanding the natural processes and controlling factors that relate to a hazard is essential for determining the location and extent of potentially affected areas, probability and frequency of occurrence, probable severity, and expected physical effects (fig. 8). Earthquakes are a good example of a hazard for which persistent data collection has led to successful hazard mitigation in many parts of the country. As a result of continuous global and regional seismic monitoring and geological and geophysical studies over the past few decades, geoscientists are gradually developing a better understanding of the processes that control the distribution, occurrence, intensity, and effects of earthquakes. In California, commitments by federal and state agencies to long-term, continuous monitoring of earthquakes have contributed to an increased level of confidence in identifying areas of high earthquake hazard and improved knowledge of earthquake effects (for example, strong ground motion). Both factors have been used extensively and successfully in regulating land-use and improving earthquake safety in new and existing buildings.

The scale and complexity of processes determine the difficulty of evaluating associated hazards. Generally, the larger the area over which the processes operate and the greater their complexity, the less 'mappable' the hazards are because of the difficulties in delineating areas likely to be affected. Often, high cost and limited technology preclude accurate delineation of areas of high exposure and definitive predictions or forecasts 


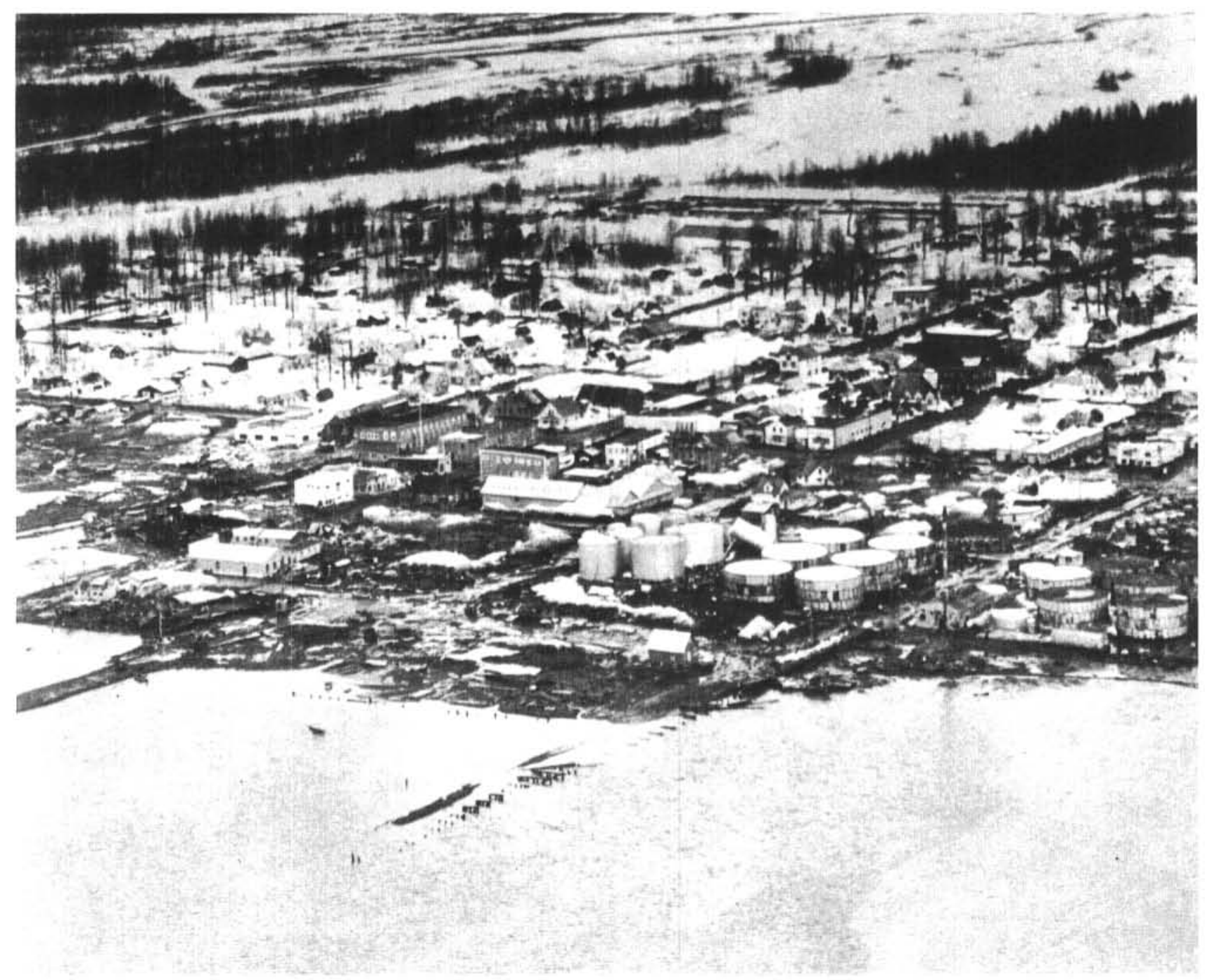

Figure 6. Old Valdez townsite after a tsunami destroyed port facilities and most of the downtown area on March 27, 1964. Photograph by J.B. Townshend, April 1964, courtesy of Alaska Earthquake Photograph Archive, Townshend collection, no. $74 \mathrm{~B}$.

of events. This condition poses legal problems in hazard mitigation, particularly in land-use regulation, because of limited technical defensibility of the boundaries of designated 'hazard areas.'

Significant geologic hazards in Alaska are listed in table 1. The 'mappability' of these hazards is based on the presence of physical features that provide a basis for areal delineation of the hazard at scales appropriate for land-use planning. For secondary hazards, mappability is based on the relative ease of delineating areas susceptible to secondary effects. For example, areas in which the intensity of ground shaking is likely to exceed given levels are very difficult to accurately delineate; hence, this primary hazard of earthquakes has low mappability. Areas that are likely to experience ground failure as a result of the given intensity of ground motion are easier to delineate; hence, ground failure, as a secondary effect of earthquakes, has higher mappability.
'Prediction capability' for catastrophic events (table 1) is based on the presence of recognizable conditions that warn of an impending event within a definite time period so that people can be evacuated and other preparations can be made.

To a large degree, legal defensibility of hazardrelated land-use regulations is related to mappability. A map adopted for regulatory use is subject to legal scrutiny; thus, the boundaries or contours depicted on it and data used to derive them must be defensible in court. Historically, two additional factors have heavily influenced court decisions and often override problems of scientific defensibility: 1) the potential loss associated with the hazard (for both life and property); and 2) the degree of restriction posed by the regulation. On the one hand, land-use regulations related to highly destructive hazards, such as floods or earthquakes, have fared better in courts than those that relate to less destructive 


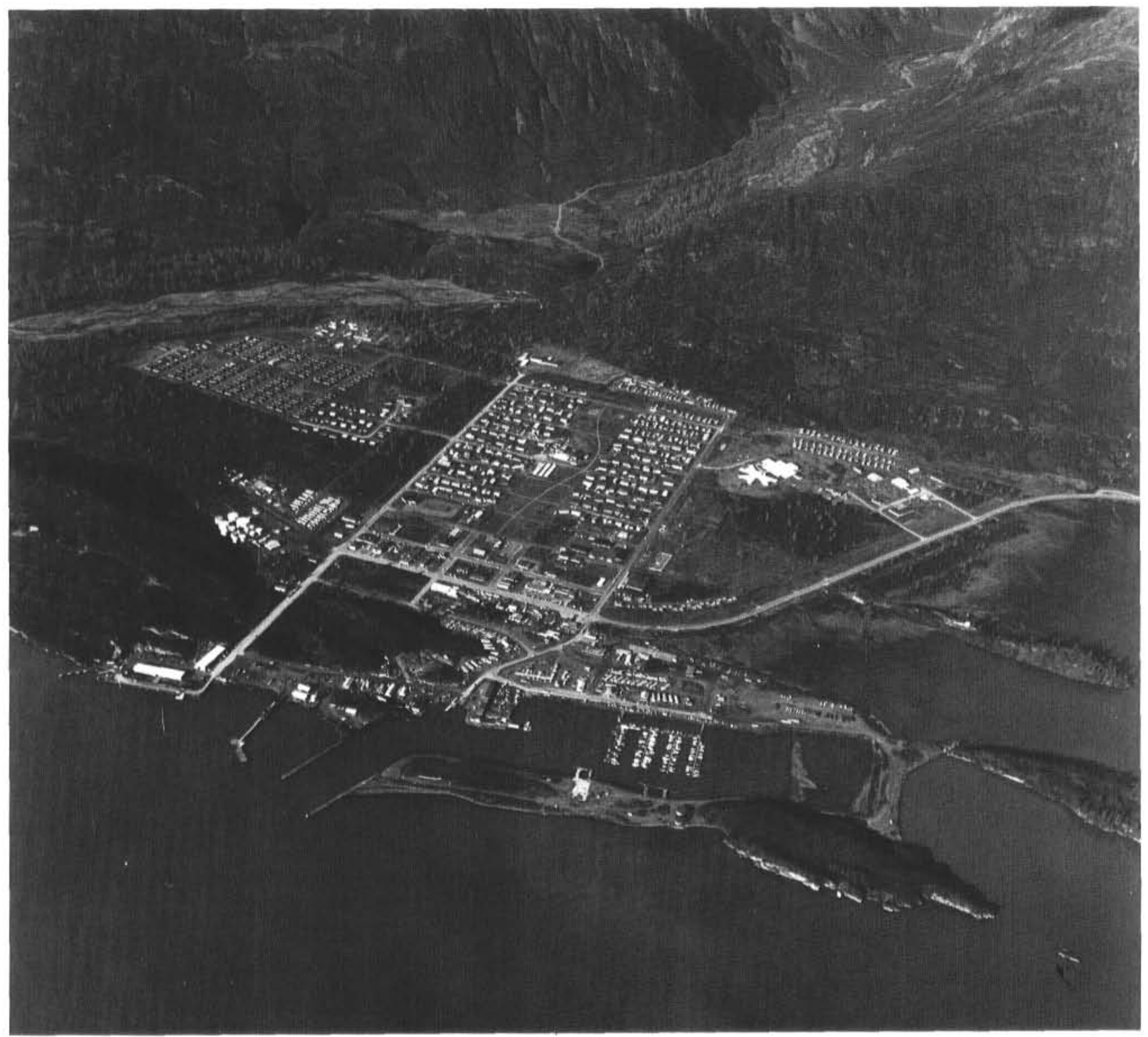

Figure 7. The new Valdez townsite near Mineral Creek, $3.5 \mathrm{mi}$ northwest of the old townsite. Photograph by Steve and Delores McCutcheon, summer 1970.

hazards, such as soil creep or lightning. On the other hand, regulations do not fare well if they are so restrictive that they infringe on fundamental liberties or do not clearly relate to the promotion of public health and safety. Generally, if a rational relationship exists between a regulation and the promotion of public health and safety, the regulation will be upheld in court. On this basis, many regulations have survived court tests, even when there were disagreements within the scientific community about the validity of the data used as criteria for the regulation (Baker and $\mathrm{McPhee}, 1975$ ).

\section{RISK ASSESSMENT}

Ultimately, the impact of a disaster on individuals and public resources depends on the success of hazard mitigation. The number of casualties, amount of publicrelief funds disbursed, and time required for recovery are reduced if mitigation efforts are successful. The effects of a disaster cannot be predicted accurately and are generally anticipated in terms of risk, that is the probable level of damage or loss given the probability of an event (hazard) occurring and its predicted effects. 


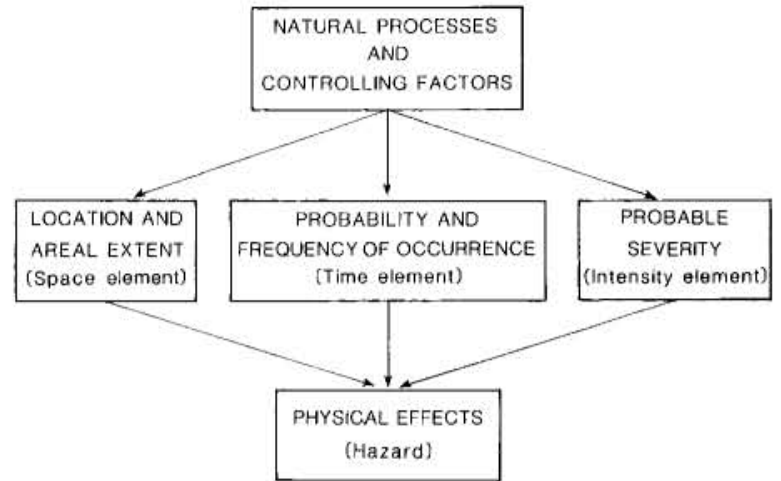

Figure 8. Flow diagram of study objectives in hazard mitigation.

Disaster preparedness must be capable of responding to the 'calculated risk' (the estimated total risk for any given level of mitigation; fig. 9). 'Residual risk' is the difference between calculated risk and 'acceptable risk' (risk that can be accommodated without undue hardship). Residual risk represents the range of unacceptable risk that can be reduced by proper management.

If the potential physical effects of a hazard are known, the risk can be estimated based on the types of facilities present or planned, cost of replacement or repair, whether or not people are likely to be present, and the socioeconomic impact of damage. Obviously, there is no direct risk from a hazard, such as a landslide, if there are no facilities or people in the affected area. Similarly, the risk of locating agricultural land or parks in the path of a potential landslide is lower than for locating a hospital or power plant in the same location. The task of economists, planners, developers, designers, and regulators is to use the hazards information provided by scientists and engineers to derive associated 'calculated risks' and then select appropriate risk-reduction and disaster-preparedness measures. A comprehensive

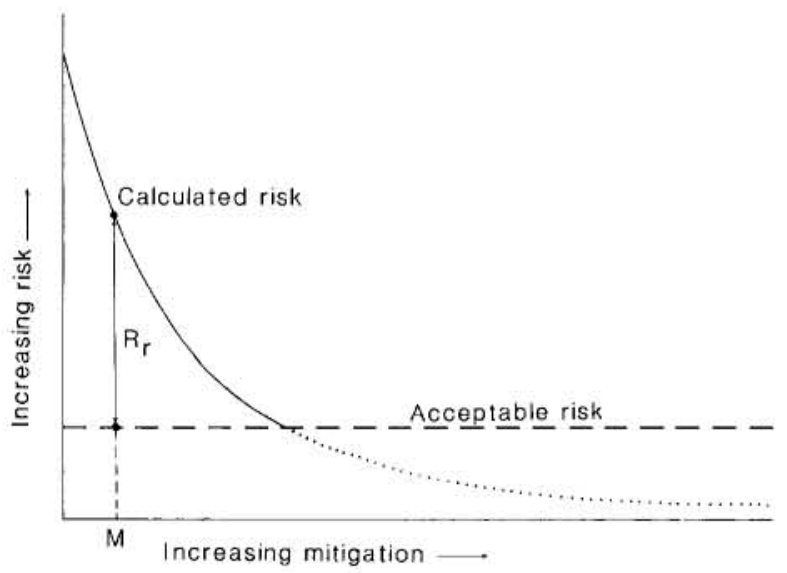

Figure 9. Relationship between risk and hazard mitigation. The residual risk $\left(R_{r}\right)$ is the difference between calculated risk and acceptable risk for a given level of hazard mitigation (M). Modified from WoodwardClyde Consultants, $1980 \mathrm{~b}$, fig. 1-1. treatment of risk assessment for natural hazards is given by Burton and others (1978) and White and Haas (1975).

\section{RISK REDUCTION}

Given adequate information about geologic hazards and the risks they pose, different risk-reduction approaches are possible: 1) land use, 2) construction technology, 3) protection works, and 4) warning systems.

\section{LAND USE}

Land-use approaches to risk reduction involve decisions about where certain types of facilities can be built. The greatest power for effective land-use planning and regulation for most facilities is concentrated at the local-government level, where most construction is regulated under authority delegated by the state. Generally, the planning body of the local government prepares a comprehensive land-use plan that serves as a base for specific zoning ordinances. Natural hazards are just one of many considerations that may affect landuse-planning and zoning decisions. If the hazard is severe, separate hazard zones may be identified to limit land use to low-density or recreational purposes. If the hazard is localized and manageable on a site-specific basis, certain siting and design practices may be prescribed. Some local governments, primarily outside Alaska, use hazard-overlay maps to add qualifiers to existing zoning categories without changing their primary designations. In all cases, local governments have provisions that allow flexibility in cases where the ordinance imposes an undue hardship or where a specific use that is not normally allowed can be permitted because it meets the standards intended by the ordinance. Where land is already in use, zoning changes generally apply only to new construction.

Hazards information can be used by individual builders to select safe sites for construction, for example, based on location of unstable slopes or ice-rich permafrost. At the state level, hazards information can be used in statewide and regional land-use plans to develop zoning regulations for state land and in site selection for state buildings and major public or critical facilities.

\section{CONSTRUCTION TECHNOLOGY}

Proper design and construction of facilities are effective in reducing vulnerability to many hazards. The most stringent regulatory measures are used in the design and construction of critical facilities. For most noncritical facilities, the power for implementing regulatory measures is at the local level. Typically a local government adopts the ICBO Uniform Building Code by ordinance and deletes or adds provisions as it deems appropriate for its jurisdiction. Sometimes, design and construction standards are incorporated into the zoning 
Potentially catastrophic geologic hazards

\begin{tabular}{|c|c|c|c|c|c|c|}
\hline Event & Causative processes & Primary hazards & Secondary hazards & $\begin{array}{l}\text { Mapp } \\
\text { Zone of } \\
\text { primary } \\
\text { hazards }\end{array}$ & $\begin{array}{l}\text { ability } \\
\text { Zone of } \\
\text { secondary } \\
\text { hazards }\end{array}$ & $\begin{array}{l}\text { Prediction } \\
\text { capability }\end{array}$ \\
\hline Earthquake & $\begin{array}{l}\text { Crustal displacement } \\
\text { Volcanic eruption }\end{array}$ & $\begin{array}{l}\text { Strong ground shaking } \\
\text { Fault displacement } \\
\text { Subsidence or uplift }\end{array}$ & $\begin{array}{l}\text { Ground failure } \\
\text { Avalanche } \\
\text { Tsunami (can also be } \\
\text { caused by earthquakes } \\
\text { outside Alaska) } \\
\text { Seiche }\end{array}$ & L-M & $\mathrm{M}-\mathrm{H}$ & $\mathrm{L}$ \\
\hline
\end{tabular}

\section{Rapid mass}

movement

Snow avalanche Snow accumulation on steep

slopes and subsequent modifi-

High dynamic pres- $\quad$ Air blast

$\mathrm{H}$

$\mathrm{H}$

M

cation by drifting, melting,

sure

and precipitation (also a

Burial

earthquakes)

Slide (landslide, rockslide, rockfall, slump)

\section{Ground displace-} ment (both vertical and horizontal)

High dynamic pres-

sure

Burial material strength, usually by water saturation (also a secondary effect of earthcoastal erosion, and river erosion)

Flow (mudflow, debris flow,

debris avalanche, slushflow avalanche)

Excessive rainfall or rapid snowmelt in areas of steep slopes and loose surficial materials (soil, vegetation, rock; also a secondary effect of volcanic eruptions)

\section{Ground displace-}

ment

High dynamic pres-

sure

Buria
Flooding following temporary damming of stream by slide deposit

Tsunami or seiche

\section{${ }^{\mathrm{a}}$ Mappability}

H - Probable location of future events can be shown on large-scale maps ( $1: 63,360$ scale or larger).

M - Variations in relative intensity or severity of hazard can be shown on laxge-scale maps, but not the location of future events.

L - Variations in relative intensity or severity cannot be shown on large-scale maps.

$\mathrm{H}$ - Individul

- Individual events can be predicted with sufficient accuracy and warning time to evacuate area.

M - Although individual events cannot be reliably predicted, conditions favorable for their occurrence can be forecast in time to issue warnings and evacuate area if necessary.

L - Neither individual events nor the conditions favorable for their occurrence can be predicted reliably enough to allow for adequate response.

of porary damming

deposit 
Table 1 (con.)

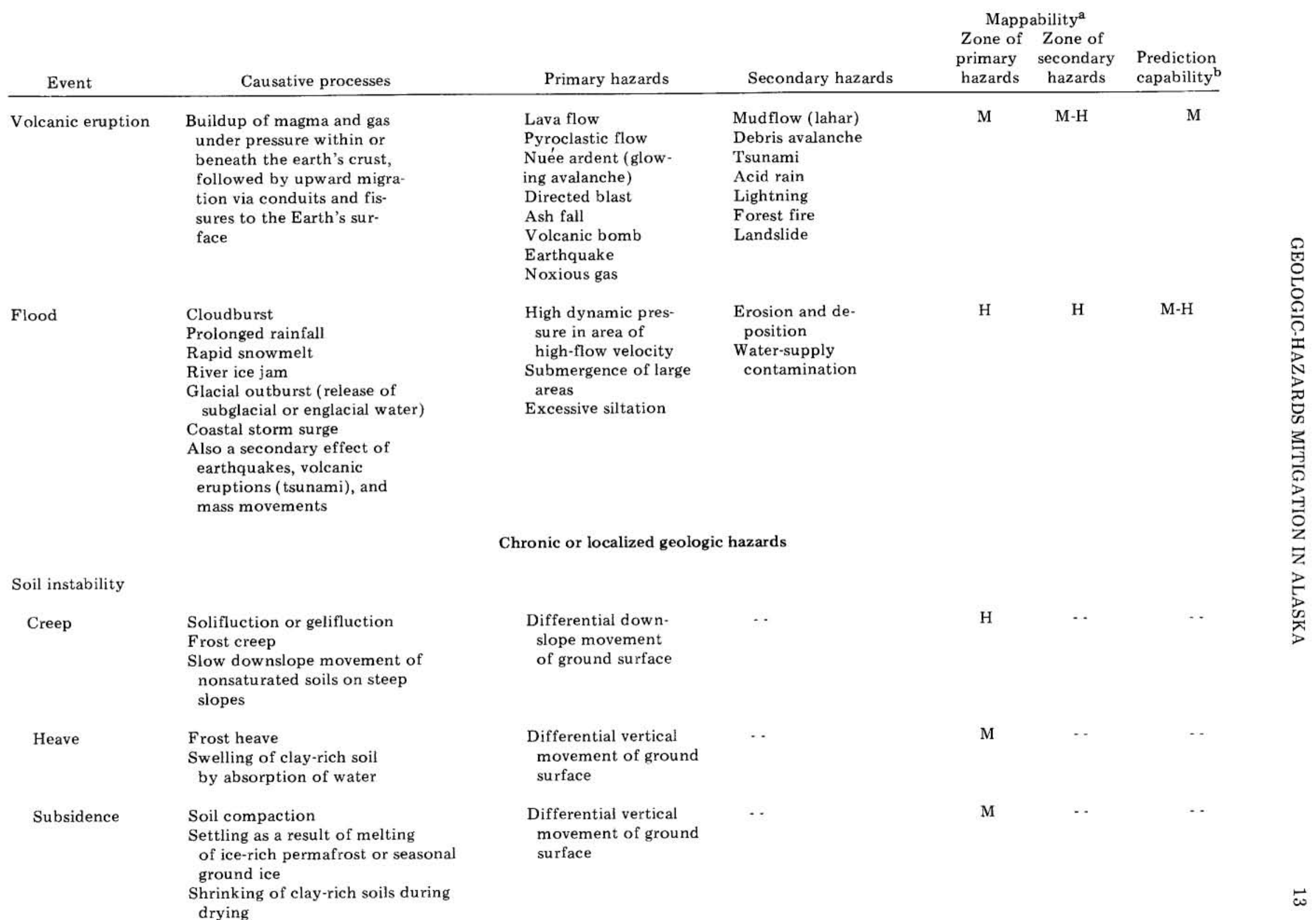




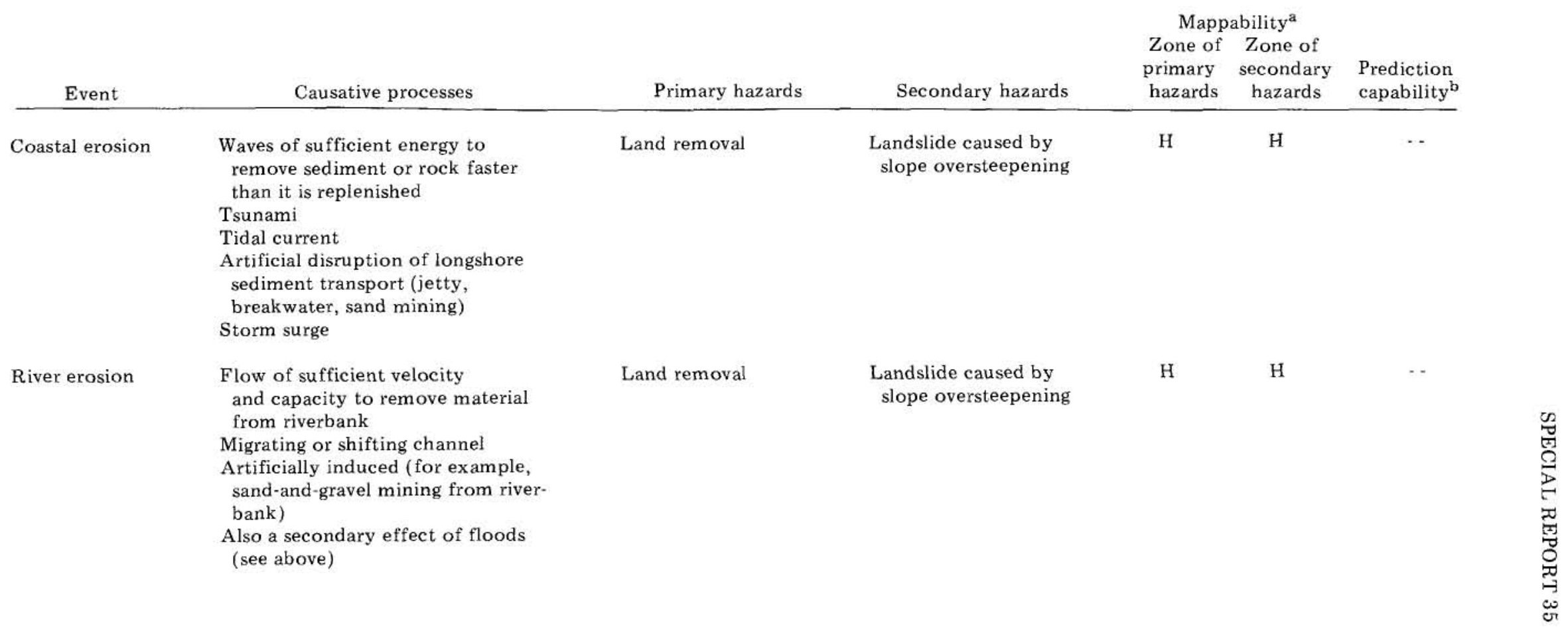


ordinances, such as minimum floor elevations in flood areas, but these are in addition to a building code that applies to the entire jurisdiction. Most states require local governments to adopt a building code and usually specify the Uniform Building Code (UBC). The State of Alaska currently does not require local governments to adopt a building code, although it gives them the authority to do so. Most major municipalities in Alaska have adopted modified versions of the Uniform Building Code. At least one municipality, the Fairbanks North Star Borough, has not yet adopted a building code.

Hazard-related design and construction requirements are not comprehensive in the Uniform Building Code. The latest version (International Congress of Building Officials, 1982) contains design requirements for wind and earthquake loads (sec. 2312) and guidelines for excavations, construction on expansive soils, grading, drainage, and erosion control to be implemented largely at the discretion of local building officials. A major limitation of the earthquake regulations in the code is that they provide design requirements only for the structural integrity of buildings under the forces of earthquake shaking and will not necessarily alleviate major foundation failures, building displacements, or misalignments that result from earthquake-induced ground failure. This omission could mislead local authorities or building designers who follow the code rigorously to expect the resultant structure to be safe from earthquakes; in fact, the structure may be built on sensitive or liquefiable soils that could cause failure from major ground displacements even before shaking reaches the level for which the structure was designed. A building so designed would probably maintain its structural integrity; however, risk of injury from falling and sliding objects is still very high if major ground failures are involved and, unless the building can be realigned, it could be a total loss.

For earthquake design, the Uniform Building Code incorporates an 'importance factor' that depends on the type of facility proposed and specifies design criteria based on the seismic zone in which the facility is located (fig. 10). Buildings with assembly rooms for 300 or more persons require earthquake-design forces 1.25 times the normal value. For 'essential facilities' (hospitals, fire and police stations, and disaster centers), the factor is 1.5 . Some state governments have legislated special design and construction requirements for such facilities beyond the provisions of the Uniform Building Code. State agencies (or federal agencies for federally supported projects) have authority to establish standards and review proposed designs and construction practices on a project-specific basis for some major public facilities, such as hydroelectric dams. Some specific approaches used in other states are discussed later in this report.

A problem in hazard-related design is that the magnitude of an event a structure should be capable of withstanding (the 'design event') is difficult to assess. The conservative approach is to design for the 'maximum credible event,' or the largest event possible considering the known natural processes or conditions in an area. For example, in a seismically active region, the maximum credible event could be a Richter magnitude 9.0 earthquake. The design cost for a Richter magnitude 9.0 earthquake may be unreasonably high for many facilities, especially if the probability is low that the event will occur during the design life of the facility. These costs may approach or even exceed the total financial loss that could result from the maximum credible event if no measures are taken. A more common approach is to design for the $100-\mathrm{yr}$ event, which is often termed the 'maximum probable event.' Floodhazard maps typically show elevations of the '100-yr flood,' a flood that can be expected to occur once every $100 \mathrm{yr}$. The type of facility will also help determine the design event. In California, the Division of Safety of Dams (DSD) requires that dams be designed so that no major amount of water is released if the maximum credible earthquake occurs.

Intensity of ground shaking at the site is the most important factor in earthquake-resistant design and depends on factors such as the distance of the site from the expected earthquake, the magnitude of the earthquake, the degree of attenuation of shaking with distance from the epicenter, and whether the site is on bedrock or sediment. Intensity of ground shaking can be expressed in terms of peak ground acceleration, duration, ground displacement, spectral velocity, or numerous other parameters. Thus, for design purposes, the maximum probable or maximum credible event must be one or more of these parameters, rather than just magnitude.

\section{PROTECTION WORKS}

A limited number of hazards can be mitigated by protection works and other structural and corrective solutions. The most common protection structures are flood-control dams and diversion works, which can substantially reduce the need to relocate existing facilities and impose new zoning restrictions to prevent disaster (fig. 11).

Although flood-protection works have successfully controlled flood hazards in many areas, two potentially serious deficiencies must be considered. First, if the protection works fail, the hazard can be much more severe than before the works were built because large volumes of water are suddenly released and the diversion works can inhibit flood water draining from the protected area. Second, protection works can promote increased development in the 'protected' area and, if the protection fails, damage and injury will be much more extensive.

Protection works have also been used successfully to control slope instability and coastal erosion. Techniques for stabilizing landslides are developing rapidly and proving to be increasingly successful. As a result, many areas in southern California that were formerly avoided because of landslide hazards are no longer considered 


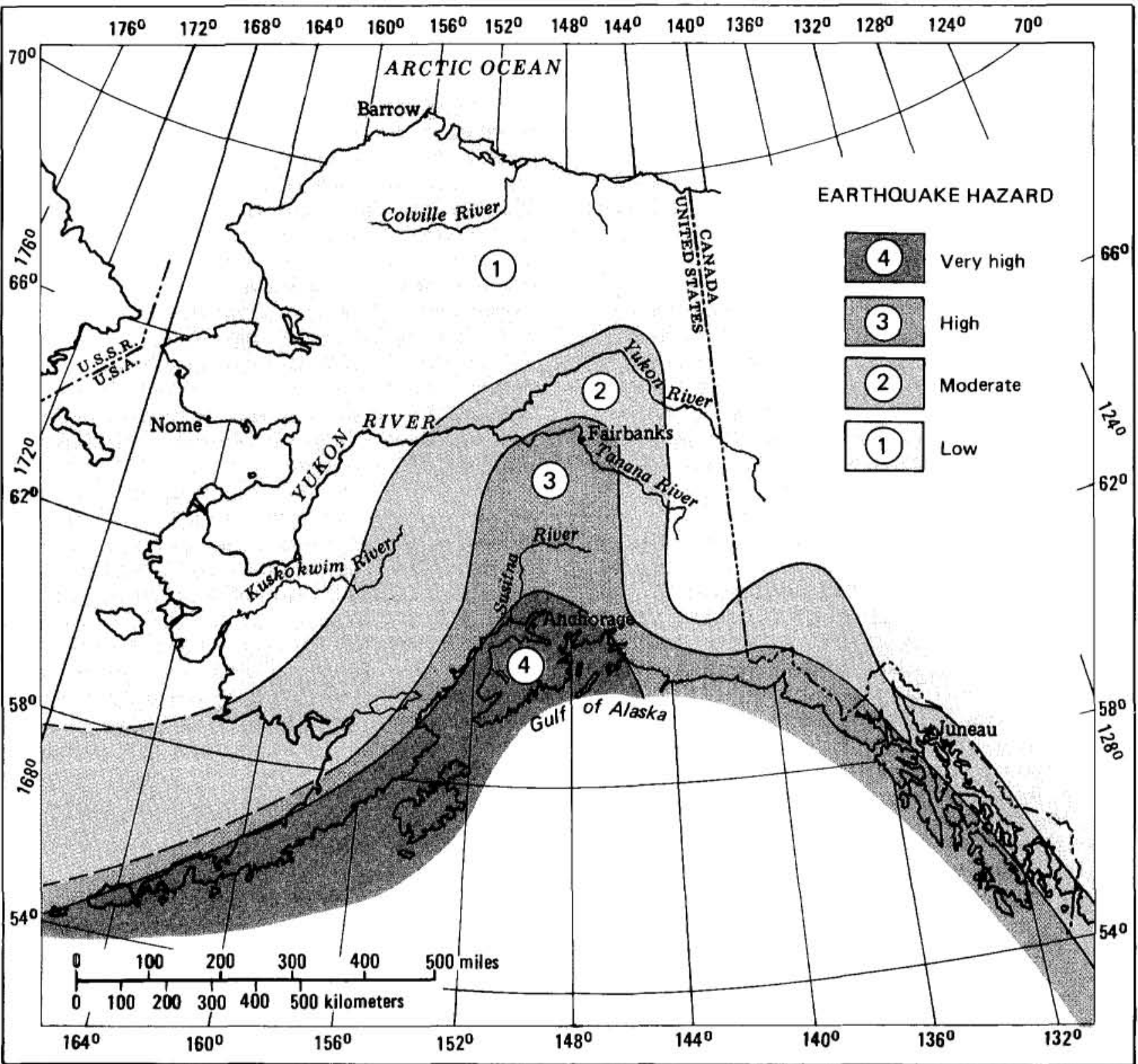

Figure 10. Seismic-zone map from the Uniform Building Code (International Congress of Building Officials, 1982). Seismic hazard is lowest in zone 1 and highest in zone 4 .

unfit for development (Leighton, 1982). Because many landslides are triggered when they become water saturated, internal-drainage systems are frequently successful, as in the Pacific Palisades area. However, not all landslides can be controlled in this manner, and other protection or stabilization methods are often prohibitively expensive. For coastal-erosion problems, jetties and breakwaters often reduce erosion in one area, but promote erosion or deposition in adjacent areas because the longshore transport of sediment is disrupted. Other protective or corrective approaches to risk reduction include firebreaks, riprap, use of vegetation for slope stabilization, and anchoring of loose structures.

Protection works and corrective measures are often necessary because land was improperly developed.
Sound land-use planning and regulation and proper selection and preparation of construction sites are the best ways to avoid expensive postdevelopment measures that may have limited success.

\section{WARNING SYSTEMS}

Warning systems are both risk-reduction and disaster-preparedness measures. They help reduce the hazard to people by providing time to evacuate an area of impending disaster and simultaneously initiate disaster-response activities. Although short-term warning of an impending event can reduce risk of personal injury during a disaster, it generally does not reduce the hazard to fixed structures and property. Warnings are possible 


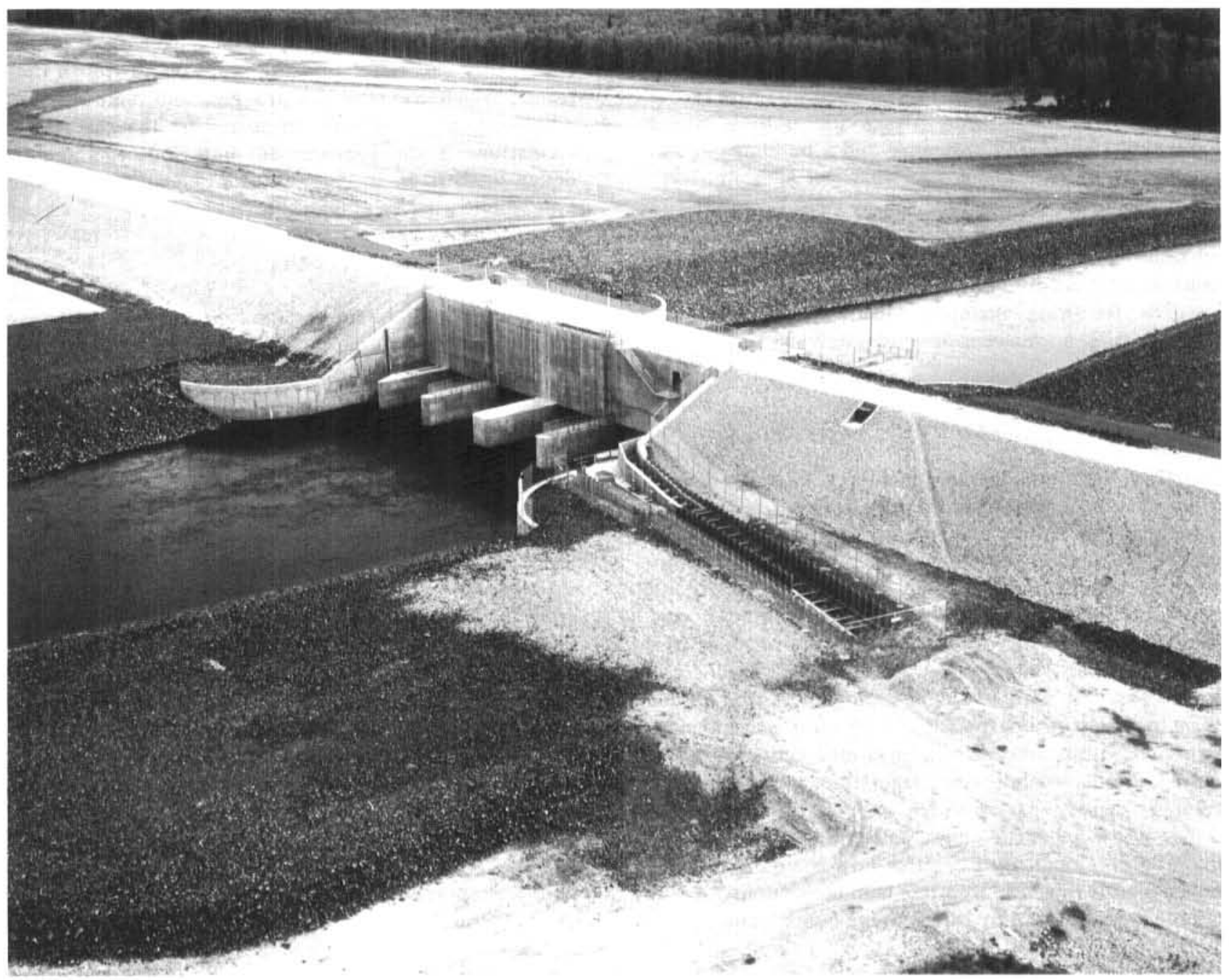

Figure 11. Floodgate in the Chena Lakes Flood Control project, about $20 \mathrm{mi}$ east of Fairbanks. The structure limits water flow to $12,000 \mathrm{ft}^{3} / \mathrm{sec}$, which is less than one-fifth the amount that flooded Fairbanks in 1967. Photograph by U.S. Army Corps of Engineers.

only if reliable hazard predictions can be issued and communication is dependable, or if adequate time lapses between an event and its effects (table 1). For example, if a major tsunami is generated by an earthquake beneath the south Pacific Ocean, there is ample time to issue warnings to Alaskan coastal communities.

Warning potential for river floods is high because predictive techniques for weather conditions that produce heavy rainfall are relatively effective, and often there is time to warn people downstream once a flood begins. Prediction of volcanic eruptions is improving rapidly, but requires constant localized seismological monitoring and measurements of ground deformation. Warnings are less effective for snow avalanches and landslides. Typically, areas susceptible to these hazards are identified and studied to determine when conditions exist that could trigger mass movements; however, it is not possible to reliably predict individual events. Although advances are being made in earthquake prediction, it will probably be a long time before they are reliable.

\section{COMBINATIONS OF APPROACHES}

No single approach to risk reduction is universally effective. In most situations, a combination of approaches is most effective, and the circumstances will dictate which methods should be emphasized. For example, in developed areas, substantial changes to zoning ordinances are unreasonable; therefore, protection works or more stringent building codes should be emphasized. Old buildings may need to be refurbished to meet new standards. The best combination of risk. reduction measures depends on the level of jurisdiction 
(local, state, or federal), the types of facilities involved, the extent and type of development, and the expected hazards. A balance between land-use and buildingtechnology approaches has proven most effective. Many local jurisdictions outside Alaska use both a strong hazards-related zoning ordinance and a building code. If adequately enforced, this approach can alleviate many problems. Zoning ordinances can be used to prohibit or restrict construction of certain types of facilities in unstable areas. Facilities that are allowed in these areas must be built according to the building code.

The following examples illustrate how combined risk-reduction approaches are commonly used in specific applications.

\section{Subdivisions}

Most local jurisdictions, including those in Alaska, establish subdivision regulations by ordinance to provide guidelines and requirements for dividing large parcels of land into smaller lots for resale. In addition to the standard requirement that developers submit plans and plats that describe proposed layouts of lots, utilities, and transportation routes for review and approval by the local planning commission, subdivision regulations sometimes deal with localized geologic hazards. Rather than impose a priori restrictions on land use and construction within subdivisions, local jurisdictions may require, through subdivision regulations, that the developer identify hazards such as unstable soils, steep slopes, snow-avalanche zones, and areas prone to flooding. The developer must describe how these hazards can be avoided through appropriate land use or construction alternatives approved by the planning commission.

\section{Excavations and Grading}

Many local governments establish site-development ordinances to prevent hazards caused by improper grading that could promote slope instability or inhibit drainage. A permit may be required for specific types of grading and excavations. Some provisions of this type are included in chapter 70 of the Uniform Building Code (International Conference of Building Officials, 1982).

\section{Commercial Facilities}

Major new commercial facilities tend to attract residential development and, if improperly located, can inadvertently promote growth in hazardous areas. Therefore, if major shopping and business centers are located away from hazardous areas, community risks will be reduced.

\section{Places of Assembly}

Special measures are often necessary for facilities, such as schools, auditoriums, churches, and other large buildings that are intended for large groups of people.
The objectives of hazard mitigation for these structures are to allow safe exit and protect occupants from injury. One highly successful measure is the Field Act in California, which regulates construction and remodeling of schools. Other successful measures are the earthquake regulations in the Uniform Building Code that require design loads to be increased by 25 percent for buildings that will be used by at least 300 people.

\section{Lifelines and Critical Facilities}

Some facilities are essential to public health and safety and require special consideration in hazard mitigation. These critical facilities would pose a major danger to the public if damaged or must remain functional during and after a disaster for public safety or essential economic activities. Included in this category are hospitals, police and fire stations, detention facilities, disaster centers, dams, nuclear and other power plants, chemical plants that handle toxic materials, water supplies, sewer systems, power lines, highways, railroads, airports, and communications systems. Schools and other places of assembly are often considered critical facilities because of the large number of people that would be affected in a disaster. Key considerations are that critical facilities must provide for safety of occupants and, in most cases, must continue to perform some or all functions. Thus, more stringent hazard-mitigation measures are required. Special building standards and site-selection procedures are needed for these facilities. Effective hazard mitigation for these structures requires periodic review during site selection, design, construction, and operational phases of the projects. This process generally must be established through federal and state legislation and regulations that specify permitting and regulatory authorities, responsibilities and rights of the contractor(s), and review functions of various agencies.

\section{THE HAZARD-MITIGATION PROCESS}

Hazard mitigation consists of four major steps: 1) collection of geologic data, 2) hazard evaluation, 3) risk assessment, and 4) risk reduction (fig. 12). The success of this process depends on effective public education. Government policy in hazard mitigation cannot be developed and implemented without support by an informed public. The most effective hazard mitigation occurs when informed individuals make wise decisions about where and how they build.

\section{ROLES OF DIFFERENT LEVELS OF GOVERNMENT}

Because most development is regulated by local governments, local risk-reduction practices have the greatest potential for success. Large public-works projects and construction of critical facilities are often regulated at the state level, where hazard-management policies are most appropriate. Because many hazards 


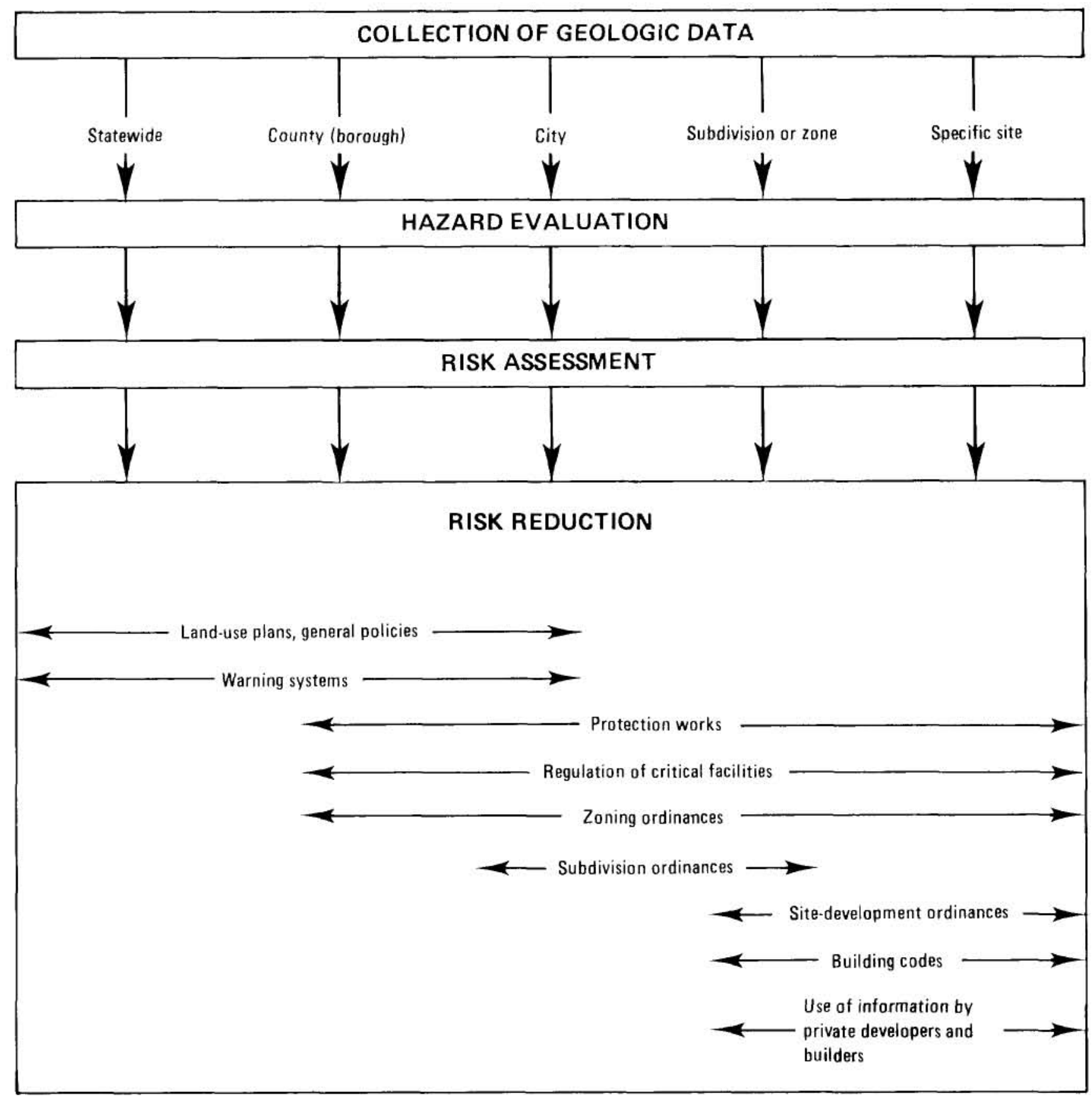

Figure 12. The hazard-mitigation process.

transcend the boundaries of local governments, adjoining local jurisdictions need to coordinate with each other to prevent conflicting plans and regulations. For example, flood-plain management or diversion practices in one community could affect other communities downstream, or zoning for major commercial facilities in one jurisdiction might promote development in hazardous areas of an adjacent jurisdiction. All regulatory activities of local governments are performed under authority granted by state government. Therefore, states need to provide legislation, clear policy guidelines, and adequate information for local governments to develop hazard. related ordinances.

In Alaska, local land-use policies are the responsibility of borough governments. Because boroughs occupy sizable land areas (larger than most counties in the contiguous states), the scale of borough land-use plans is ideal for incorporating geologic-hazards considerations. However, only 25 percent of Alaska is subdivided into boroughs; therefore, when problems 
arise in areas outside the organized boroughs, coordination between borough and state or federal governments is necessary.

Because federal, state, and local governments have different levels of financial and personnel resources and different management responsibilities, their roles in hazard mitigation are also quite different (table 2). Local governments generally do not have the financial resources or personnel to conduct major geologic-hazards studies, particularly for large-scale and potentially catastrophic hazards like earthquakes and volcanic eruptions. State geological surveys are equipped to conduct these types of studies, publish information on hazards that affect the state, and provide technical assistance to local governments. Other state agencies can assist with land-use plans, ordinance development, building-code enforcement, and other risk-reduction measures. The federal government assists states by providing topical information on geologic-hazards processes, performing research, and mapping on a regional scale. State and federal governments have disaster-relief funds to assist communities if a disaster occurs. Availability of federal disaster-relief funds is becoming increasingly contingent on effective state and local risk-reduction measures that follow a disaster.

\section{GEOLOGIC-HAZARD-MITIGATION PROGRAMS IN OTHER STATES}

Twenty-seven states, including Alaska, have adopted some form of legislation that authorizes or requires measures for geologic-hazard mitigation. The comprehensiveness and effectiveness of hazards legislation vary widely among these states and depend on how strongly the statutes are worded and how actively they are implemented. In some states, hazards legislation is ineffective because it authorizes measures that are never implemented. Of the 27 states with hazard-mitigation legislation in effect in 1982, 13 (including Alaska) adopted the Example State Disaster Act published by the Council of State Governments (1972). The disasterprevention section of the act calls on the Governor and the state Division of Disaster Emergency Services to study disaster-prevention matters, land uses, and construction in the state and to recommend measures to reduce or prevent harmful consequences of a disaster. The Council of State Governments Disaster Act does little to mitigate hazards because it is primarily disasterpreparedness legislation. The act relies on follow-up legislation, policies, and development of agency programs to be effective for hazard mitigation. Only a few states have enacted programs in which hazards con. siderations are integral to land-use, development, and construction policies. The most common approach at the state level is enactment of legislation that initiates development of local mitigation programs and broad state policies and sets up state regulation of certain facilities.
Hazard-mitigation programs in California and Colorado were reviewed to determine whether they could serve as models for similar programs in Alaska. Both states have significant geologic hazards that are similar to those in Alaska and have tested their programs over longer periods than most other states. Information used in this review includes state statutes and regulations, published reports, and numerous discussions with individuals involved with the programs at state and local levels.

\section{CALIFORNIA}

Hazard-mitigation programs in California are largely an outgrowth of public reaction to natural disasters, beginning with legislation that was developed after the St. Francis Dam failed in 1928 (Campbell, 1976). This approach has been responsible for a wide variety of seemingly unconnected special-purpose programs. For example, school construction has been strictly regulated for earthquake safety under the Field Act since 1933, when an earthquake extensively damaged schools in Long Beach. Similar standards for hospitals (Hospital Seismic Safety Act) did not appear until after the 1971 San Fernando earthquake when extensive damage occurred and dozens of people were killed at four major hospitals and many other medical facilities. In recent years, California has begun to develop more farsighted, coordinated programs in anticipation of future events.

Surges in public emotion that follow disasters have been responsible for the episodic development of hazards-related legislation in California. Two consequences are the need for extensive corrective action by the legislature on hastily prepared bills and, until the early 1970 s, the lack of comprehensive, well-prepared legislation. A high percentage of hastily prepared bills were passed by the Legislature during the emotional aftermath of disasters. Lulls between disasters allowed sufficient time to prepare good legislation, but were also periods of apathy during which few good bills were passed (Slosson, 1975).

Despite this erratic process, many successful programs that address specific problems were developed. In recent years, Californians and their legislators have begun to support more advanced planning and wellprepared, long-range legislation like the Alquist-Priolo Special Studies Zones Act and establishment of the Seismic Safety Commission.

Many lessons can be learned from the history of hazard-mitigation programs in California. The lessons are particularly applicable to Alaska, which is in a position similar to that of early 20th-century California. Economic development is still in its youth, one major damaging earthquake has occurred, and the likelihood is high that additional events will occur (as they did in California) that will take a progressively greater toll of lives and property unless the disaster potential is reduced. Ironically, the 1964 Great Alaska Earthquake 
Table 2. Suggested roles of federal, state, and local governments in hazard mitigation and disaster preparedness. Modified from Council of State Governments, 1979; Hays and Shearer, 1981; and Nichols and Campbell, 1971.

\section{Federal government}

Policy Long-term national goals and policies

Financial assistance for state and local governments to develop policies and programs

Research

Technical

services

Risk reduction

Disaster preparedness
Support topical research on geologic processes and regional mapping of hazards Support engineering and socioeconomic studies

Support permanent monitoring (for

example, earthquakes) at regional scale

Conduct postdisaster studies

Supply geologic data, small-scale regional

Provide assistance to state and local governments

Develop model building codes and land-use plans

Provide financial support for local land-use plans

Support development of risk-reduction building technology

Protection works (for example, U.S. Army

Corps of Engineers)

Issue predictions and warnings

Federal disaster-relief funds and loan programs Provide advice and financial incentives for state and local preparedness plans

Maintain major response capability (for example,

U.S. Army National Guard, Corps of Engineers)

Offer or subsidize hazard insurance maps, and information

\section{State government}

Enabling legislation for local governments

Statewide goals and policies

Statewide land-use plans

Establish interdisciplinary councils

to recommend public policy

Financial assistance to local governments

Support research on geologic hazards in the state and mapping of hazards at local to statewide scales

Support long-term monitoring at statewide scale

Conduct short-term postdisaster

studies in cooperation with federal government

Supply geologic data, large-scale maps, and information to local governments and public

Provide technical assistance to local governments

Develop guidelines for local risk-reduction measures

Develop model zoning ordinances

Establish laws and regulations for

siting and design of lifelines and critical facilities

Set hazard-mitigation requirements for construction projects using state capital funds or loans

Protection works

Evaluate predictions, issue warnings, and advise as to appropriate response

State disaster-relief funds

Disaster-preparedness plans and programs

Public education

Assistance to local governments in developing preparedness plans

\section{Local government}

County (borough) land-use plans

Perform or require local studies of specific hazards

Assemble and evaluate data

relevant to local hazards issues

Adopt and enforce zoning and site development ordinances, building codes, and subdivision regulations

Local preparedness plans

Public education with emphasis on

individual preparedness 
inspired the establishment of California's Joint Committee on Seismic Safety, which in 1974 became the Seismic Safety Commission (Campbell, 1976).

The major state legislative programs that relate to geologic-hazard mitigation in California, their development, and some of their strengths and weaknesses are reviewed below.

\section{STATE PLANNING AND ZONING LAW: GENERAL PLAN}

In 1927, California passed legislation that allows local governments to prepare a general plan to document their land-use and development policies. In 1955, the general plan became a state requirement for all counties and cities, and two 'elements' (land use and circulation) were addressed (California Government Code, secs. 65300-65302). By 1971, seven more elements were added, including a 'seismic-safety element' and a 'safety element' required by amendments that were passed soon after the San Fernando earthquake. Also in 1971, the most significant feature relating to implementation was added: the requirement that all zoning ordinances and subdivision approvals be consistent with a jurisdiction's general plan.

State law requires the Governor's Office of Planning and Research to prepare, adopt, and periodically revise state guidelines to assist local governments in preparing their general plans. These guidelines constitute California's official interpretation of the planning law and give detailed instructions and suggestions on content, format, and procedures (California Office of Planning and Research, 1980).

As new elements were added to requirements in the general plan, local governments were given deadlines for their preparation and adoption. All seismic-safety and safety elements were to be completed by 1976 . As of January 1977,81 of the 412 cities and 19 of the 58 counties had not adopted a seismic-safety element (California Seismic Safety Commission, 1977a). Only the housing element requires an update every $5 \mathrm{yr}$. However, the guidelines strongly encourage thorough review and revision of all elements at least every $5 \mathrm{yr}$ to reflect new conditions and public attitudes.

Various portions of each general plan must be submitted to appropriate state agencies for review. For example, a copy of the adopted seismic-safety element and associated technical data must be submitted to the state Division of Mines and Geology (DMG). With one exception (unrelated to hazards), state agencies do not have approval authority over general-plan elements. The purpose of submitting review copies is to inform state agencies that have responsibilities related to certain aspects of the general plan and to provide those agencies with an opportunity to suggest revisions or improvements.
The seismic-safety element of the general plan must consist of an "identification and appraisal of seismic and geologic hazards, such as susceptibility to surface ruptures from faulting, to ground shaking, to ground failures, or to effects of seismically induced waves such as tsunamis and seiches." The safety element must describe proposed features for community protection from those hazards. Flooding must be addressed in other elements of the general plan, including the land-use element (which identifies areas subject to flooding) and the conservation element (for conservation aspects of flood control). State guidelines note that the division of the general plan into separate elements "is more a product of the incremental nature of the legislative process than a conscious design." Thus, local planning commissions are encouraged to combine the seismicsafety and safety elements into one section devoted to the hazard issues. Plans for implementing the AlquistPriolo Special Studies Zones Act, described below, must also be included in the general plan if all or a portion of the local jurisdiction lies within one zone.

Only $1 \mathrm{yr}$ after all seismic-safety elements were due to be completed, the California Seismic Safety Commission (SSC) (1977a) reviewed the seismic-safety requirement and found that it had already begun to produce positive effects. However, SSC recognized that it could be a long time before a major earthquake tested the requirement's effectiveness. The seismic-safety requirement forced local identification of earthquake problems, formulation of related policy, and significantly impacted land-use decisions. When a questionnaire was sent to four cities and four counties, most jurisdictions responded that information generated by the seismic-safety requirement provided important seismic and geologic data for decisionmakers at all levels of government and increased the awareness of planners, public-works officials, building departments, and elected representatives of seismic and geologic problems related to land-use planning. The review committee concluded that, despite some weaknesses, the seismic-safety requirement produced very significant benefits in the interest of public safety.

One weakness of the planning law is that the state is unable to ensure that general plans or their individual elements are adopted and periodically updated. No penalties are prescribed for failure to complete a general plan, nor are financial incentives given. However, any property owner, resident, state agency, state attorney general, or any aggrieved party may sue to enforce the requirement for adoption of a general plan and consistency of subdivision approvals and zoning. The courts may issue a writ of mandate for compliance with the requirement or set aside city or county approval of an action that is inconsistent with the plan. Apparently, court action is the only means of ensuring compliance (J.L. Mintier, oral commun., 1982). 
Another weakness is that no single agency is responsible for reviewing the adequacy of general plans. Seismic-safety elements are submitted to the Division of Mines and Geology (DMG) for possible review, but approval is not required. Also, DMG comments concentrate on the technical adequacy of geological and geophysical information and do not address application of the information to planning (J.L. Mintier, oral commun., 1982). The California Seismic Safety Commission (1977a) found a wide variation in content and quality of plans. Although SSC conceded that variation in content and organization is inevitable, and to a certain extent desirable, it concluded that lack of checks on quality allowed the adoption of many seismic-safety elements that contain misleading or erroneous information. Consequently, questions are raised about the validity and effectiveness of seismic-safety elements in a planning document.

After a general plan is adopted, implementing it through such means as revising existing zoning laws, updating building codes, and conducting safety inventories of existing buildings is difficult. Although the law requires that actions such as subdivision approvals and zoning changes be consistent with the general plan, it cannot ensure that new actions stipulated by the plan are implemented. Mintier and Stromberg (1982) surveyed seven jurisdictions and found that the safety element has not functioned successfully as a planning document. For example, all seven jurisdictions had adopted policies in their general plans that called for an inspection and rehabilitation program for hazardous buildings, but none have implemented their programs. Instead, the seismic-safety element has been most effective as an educational tool for planners and elected officials and as a broad mandate for local governments to learn about the geology of their areas and to mitigate hazards through project reviews.

\section{ALQUIST-PRIOLO SPECIAL STUDIES ZONES ACT}

The Alquist-Priolo Special Studies Zones Act was passed in December 1972 and became effective as part of the California Public Resources Code (secs. 2621 to 2630 ) in March 1973. As of 1980 , the act had been amended four times. The law requires the State Geologist to delineate special-studies zones (normally $1 / 4 \mathrm{mi}$ wide or less) that encompass all 'potentially and recently active' faults that constitute a possible hazard to structures from surface faulting or fault creep. Before any 'project' (defined by the law) within a special-studies zone is approved, cities and counties must require a geologic report that defines and delineates any hazard of surface fault rupture. Project approvals and geologic reports must comply with policies and criteria set by the State Mining and Geology Board (SMGB). The act also requires that sellers of real property located within a special-studies zone disclose that fact to prospective buyers. Table 3 summarizes responsibilities and functions under the act.
According to the law, a 'project' is any new realestate development or structure intended for human occupancy, with the exception of single-family woodframe dwellings that do not exceed two stories and alterations that do not exceed 50 percent of the structure's value. The SMGB defines an active fault as one that shows evidence of surface displacement within the last 11,000 yr (Holocene time). To delineate specialstudies zones, the State Geologist defined a 'potentially active' fault as one that shows evidence of surface displacement during the last 2 m.y. (Quaternary time), and included 'recently active' faults in the 'potentially active' category. Since January 1, 1977, special-studies zones have been delineated based only on faults that show evidence of activity during Holocene time.

The DMG produces maps that show special-studies zones on U.S. Geological Survey 1:24,000-scale topographic base maps (fig. 13). An ongoing fault-evaluation program selects faults that can be located in the field with sufficient precision and confidence to indicate that site-specific investigations required by law will be successful. Positions of the special-studies zones are controlled by the positions of mapped fault traces. Zone boundaries are straight-line segments that join locatable features on the ground. The zones have a total width of about $1 / 4 \mathrm{mi}$ except where there are closely spaced, parallel fault strands in which case the zone may be wider. As of January 1, 1980, 288 special-studies-zone maps had been issued; 24 of these had been revised. Approximately 24 counties and 69 cities are affected (Hart, 1980). The DMG is required to review new geologic and seismic data to revise existing zones or delineate new ones.

Local governments are responsible for determining, through requirements placed on the developer or builder of projects within a special-studies zone, whether a potential fault hazard exists for proposed structures and their occupants. Fault information shown on DMG special-studies-zone maps is not intended to be sufficient for this purpose. Along with the permit application, the developer or builder must submit a report prepared by a geologist registered in the State of California that addresses potential surface fault displacement through the project site. As required by SMGB policies, the city or county must then retain a registered geologist to review the report for adequacy. The city or county must approve the report before a permit is granted. The policies of SMGB prohibit construction of structures for human occupancy within $50 \mathrm{ft}$ of an active fault. Therefore, to be eligible for a permit, a builder or developer must prove there are no active faults within $50 \mathrm{ft}$ of the proposed project. The board has set $50 \mathrm{ft}$ as the minimum standard, and encourages cities and counties to impose more restrictive criteria for large or critical structures.

The DMG has found that the investigative methods, documentation, report quality, and validity of conclusions are inadequate in many fault-evaluation reports (Hart and Wagner, 1975; Stewart and others, 1977). 
Table 3. Summary of responsibilities and functions under the Alquist-Priolo Special Studies Zones Act (Hart, 1980).

\section{State Geologist}

1. Delineates special-studies zones; compiles and issues maps to cities, counties, and state agencies.

a. Preliminary maps for review.

b. Official maps.

2. Reviews new data.

a. Revises existing maps.

b. Compiles new maps.

3. Approves requests for waivers initiated by cities and counties.

\section{State Mining and Geology Board}

1. Formulates policies and criteria to guide cities and counties.

2. Serves as Appeals Board.

Although not required to do so by law, DMG published guidelines for the evaluations and a suggested outline for the reports (Hart, 1975).

Implementing the Special Studies Zones Act at the local level has additional problems, some of which remain unresolved. Most difficulties result from lack of clear definitions and requirements and from inconsistencies between SMGB policies and the Special Studies Zones Act. For example, the law is not clear about what basis is used to establish property values of buildings proposed for alteration to determine if a geologic report is required (based on 50 percent of the value). Whether 'structures for human occupancy' include warehouses, studios, and buildings added to an existing facility, or if the requirements apply to expansion of existing uses and changes in occupancy is not clear. Policies of SMGB prohibit building any structures for human occupancy within $50 \mathrm{ft}$ of an active fault, whereas the Special Studies Zones Act exempts certain structures (for example, single-family dwellings) from that requirement. Many problems could be resolved by amending the act and revising SMGB policies (California Seismic Safety Commission, 1977b).

More serious implementation problems arise because the Special Studies Zones Act imposes uniform, statewide requirements that do not allow flexibility for local differences in government, level of development, and conditions that preclude accurate delineation of surface fault traces. For example, how can the trace of a suspected active fault be located in an urbanized area that has no predevelopment aerial photography and is largely covered by fill? Where faults must be located by remote-sensing methods, such as seismic and magneto.
Cities and Counties

1. Must adopt zoning laws, ordinances, rules, and regulations; primary responsibility for implementing act.

2. Regulate specified 'projects' within special-studies zones.

a. Determine need for geologic reports before project development.

b. Approve geologic reports before issuing development permits.

c. May initiate waiver procedures.

3. May charge reasonable fees for administrative costs.

\section{Other}

1. Seismic Safety Commission - advises State Geologist and State Mining and Geology Board.

2. State Agencies - prohibited from siting structures across active fault traces.

3. Disclosure - prospective buyers of any real property located within a special-studies zone must be notified of that fact.

meter surveys, it is generally not possible to date the displacement or accurately extrapolate the surface trace. Many local governments alleviate uncertainties in clarity, definition, and application of the law by imposing their own more restrictive ordinances. For example, if the setback is increased to $100 \mathrm{ft}$, the surface trace of a fault that has no surface expression can be approximately mapped because it incorporates a 50 - $\mathrm{ft}$ margin of error beyond the setback required by SMGB. To alleviate uncertainties in how the law is applied to individual properties that lie partially within a special-studies zone, one city adjusted zone boundaries to follow property lines and street centerlines so that lots originally crossed by a zone boundary are now entirely within the zone (California Seismic Safety Commission, 1977b).

Requirements imposed by the Special Studies Zones Act and by board policies created a considerable demand for registered geologists. Two registered geologists are required for all new projects in every specialstudies zone in every city and county affected by the act. One registered geologist prepares the report for the developer or builder, and the other reviews it for the permitting body. Many local governments regard this requirement as excessive and have recommended that they be allowed to hire one geologist to prepare a report for the entire portion of a special-studies zone that transects their respective jurisdictions and that DMG provide the review. Because of the scarcity of registered geologists, some people believe that it is impractical and not in the public interest to require that the reports be reviewed by registered geologists. One city geologist found that "many geologists preparing reports are unaware of recent trends in fault analysis, rely on 


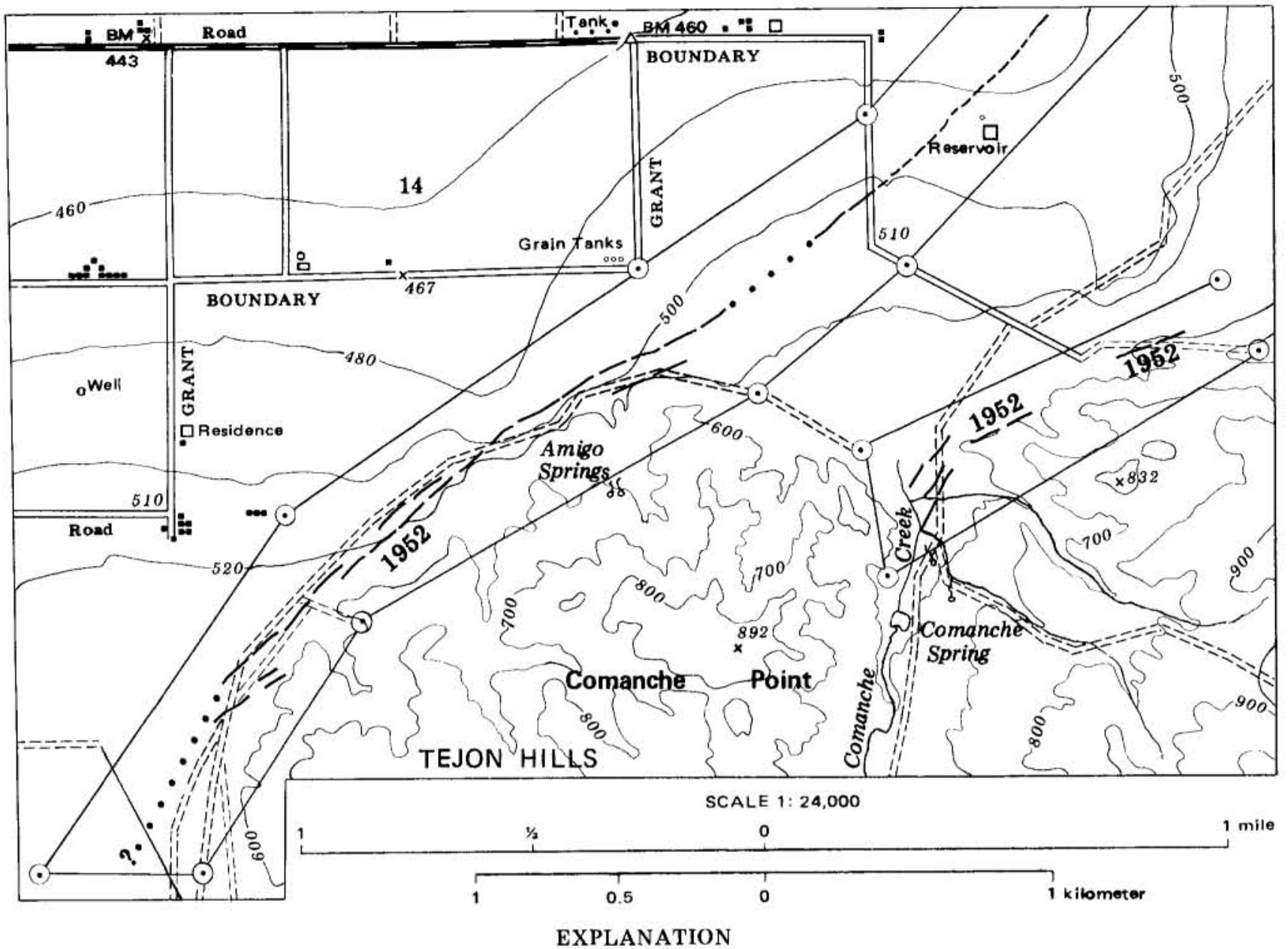

1952

Potentially active faults

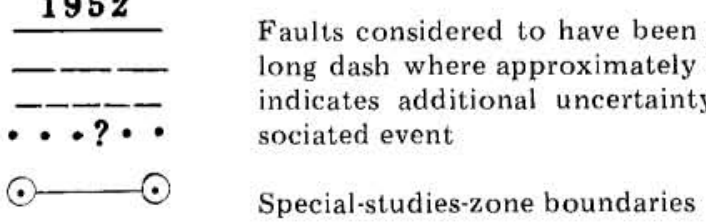

* Beginning with maps issued January 1, 1977, special-studies zones have been delineated only for those faults considered to have been active during Holocene time.

Figure 13. Example of a Special Studies Zones map. These maps are published by the California Division of Mines and Geology in accordance with the Alquist-Priolo Special Studies Zones Act of 1972. Modified from Hart, 1980, p. 7.

inappropriate methods of investigation, and restrict themselves too tightly to a site, referring only to published regional data rather than using field-checked air-photo interpretation" (California Seismic Safety Commission, 1977b).

The disclosure requirement presents implementation problems and is not clear about responsibility for its enforcement. Most local governments assume the state is responsible for enforcement, but a few have clarified their own policies and procedures for disclosure. Most cities and counties do not know whether a seller discloses to prospective buyers that the subject property lies within a special-studies zone. Many sellers and real estate agents are unaware of the requirement, even though they may be aware of the act. One county requires the owner to sign a statement, recorded with 
the deed, that acknowledges the potential hazard, but only for new projects that require a geologic report under the Special Studies Zones Act. Enforcement of the disclosure provision for property that does not require a report is much more difficult because a permit is generally not involved, and the county is therefore unaware of a sale until after it is recorded. Apparently the only real compliance incentive is the threat of possible court action against the seller if an unnotified buyer suffers losses from fault damage (California Seismic Safety Commission, 1977b).

A major concern among property owners has been the potential impact of the Special Studies Zones Act on property values and development interests. Some cities and counties have in turn expressed concern about possible liability for lots declared 'unbuildable.' Although there apparently are no documented cases of financial loss due to the act, one would expect such losses to occur when property intended for construction is purchased, later included in a special-studies zone, and found to be located on an active fault. After the initial loss, however, subsequent investments in the property should not be affected because restrictions on property use would not change (California Seismic Safety Commission, 1977b).

The Special Studies Zones Act has successfully restricted development along mapped active faults in California. Its effectiveness in reducing the hazard from surface fault rupture has not been tested because no damaging surface ruptures have occurred in a specialstudies zone since the law went into effect. Whether particular faults are active or inactive is often disputed, because the age of most recent displacement is based on interpretations on which competent geologists may disagree, especially when there is insufficient conclusive evidence. When a geologic report is accepted, a jurisdiction reduces its liability if it takes the conservative position and regards faults of questionable age as active and imposes the setback requirement for an active fault.

Locating boundaries of special-studies zones has often been a problem for local agencies. Some landmarks that were used to identify turning points no longer exist because they were based on old topographic maps or were not field checked (California Seismic Safety Commission, 1977b). Once turning points are located, boundaries are rarely challenged, even though they represent no identifiable geologic boundary between areas of greater and lesser hazard. This approach to mapping hazard areas has generally been upheld by court decisions in many states, as long as there is a rational relationship between delineation of the hazard area and the promotion of public safety (Baker and McPhee, 1975). Boundaries that can be easily located by the enforcing agency are preferable to boundaries that follow natural discontinuities in hazard severity. Specialstudies zones only delineate areas where fault-evaluation reports are required and do not themselves impose $a$ priori restrictions on land use. Therefore, precise geologic data to defend boundaries is not needed.

\section{FIELD, GARRISON, AND GREEN ACTS: SCHOOL BUILDINGS}

California's Field Act (Education Code, secs. 39140 to 39156 and 81130 to 81146 ) is one of the best known and documented success stories in geologic-hazard mitigation. The Field Act resulted directly from public reaction to the extensive damage inflicted on schools in Los Angeles County during the Long Beach earthquake of March 10,1933 (Richter magnitude 6.3). Although accurate figures are not available, about 70 schools were demolished and many more severely damaged (fig. 14). Assemblyman Don Field introduced the bill, which quickly passed both houses of the state legislature and was signed into law on April 10,1933, exactly one month after the earthquake.

The Field Act regulates new construction of primary and secondary schools and community colleges to ensure conformance with minimum design standards for protection of life and property during an earthquake. Alterations or additions that exceed $\$ 20,000$ are similarly affected. The Garrison Act was enacted in 1939 and amended by the Greene Acts in 1967, 1968, and 1974, to require that schools built before 1933 be inspected and, if judged unsafe, rehabilitated to Field Act standards or abandoned.

The Field Act has several requirements:

1. Plans for construction or alteration of school buildings must be prepared by registered architects or structural engineers.

2. Plans must be reviewed and approved by the Office of the State Architect, Department of General Services, before a construction contract is awarded to ensure that the plans meet standards of the state building code (ICBO Uniform Building Code by reference).

3. Construction must be continuously inspected by registered inspectors to ensure compliance with approved plans.

4. The design architect or structural engineer must observe the construction and prepare any necessary design changes.

5. All parties (designers, contractors, and inspectors) must file reports (under penalty of perjury) that verify compliance with the approved plans.

Because the act references the state building code (part 2, title 24, California Administrative Code), it does not impose its own standards for school-building design, and therefore remains flexible to accommodate changes in the code as earthquake-engineering technology 


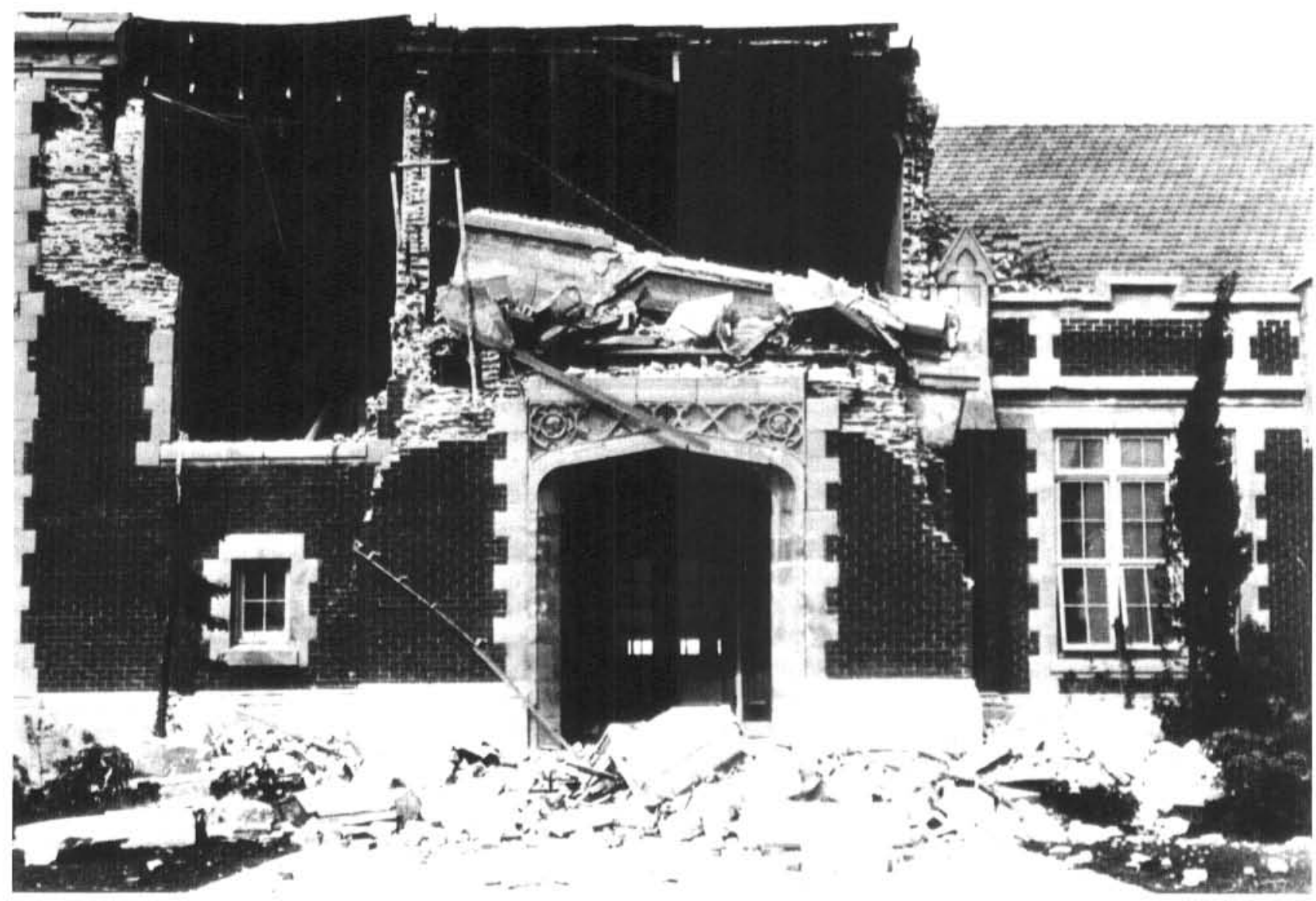

Figure 14. John Muir School, Long Beach, California, damaged by the March 10, 1933, earthquake (Richter magnitude 6.3). Photograph by W.L. Huber.

advances. In effect, the Field Act simply strengthens uniform implementation of the code for school construction by placing strict design-review and approval responsibility and inspection enforcement in the hands of the State Architect. The law requires a filing fee of 0.6 to 0.7 percent of the estimated construction cost (\$250 minimum) to defray the state's costs of implementing the law.

Other provisions of the Education Code (secs. 39002 to 39002.5 and 81033 to 81033.5 ) require geologic and soils-engineering studies of prospective school sites located within a special-studies zone (Alquist-Priolo Act) or an area designated geologically hazardous in the local general plan. A copy of the report must be submitted to the Department of Education. The site selection is not approved if the construction effort required to make the school building safe for occupancy is economically unfeasible.

The Field Act has proven its effectiveness through several damaging earthquakes since 1933. During the Kern County earthquake of 1952 (Richter magnitude 7.7) and the San Fernando earthquake of 1971 (Richter magnitude 6.4), many buildings not built to Field Act standards completely collapsed, but nearby school structures built in compliance with the law survived nearly undamaged (Campbell, 1976; Mann, 1979).

When Mann (1979) reviewed the Field Act and related laws for the Seismic Safety Commission, he concluded that the only major problem is that early (pre-1950) schools built to comply with the Field Act may no longer conform to modern standards because of frequent upgrading of building codes. The Field and Garrison Acts contain no provisions for periodic inspections and possible rehabilitation of schools that once complied with the law. Although many early structures are probably safe, Mann (1979) recommended that selected schools built from 1933 to 1950 be inspected by the Office of the State Architect and professional societies.

School boards faced with building a new school are concerned that Field Act requirements will make construction prohibitively expensive. In response to their concern, Mann (1979) compiled information from design professionals and estimators and showed that the total added cost of materials, labor, inspections, fees, and paperwork related to Field Act requirements historically has been a maximum of 5 percent of the total construction cost. This increase is partially offset by 
lower insurance rates available for schools that comply with the Field Act. In addition, because of the high probability of exposure to a significant earthquake during the 50-yr design life of any school in California, the relatively minor additional investment during construction is likely to prevent major earthquake-related repairs. With one exception, no school built to Field Act requirements has been damaged by an earthquake to the extent that major repair was necessary. However, the damage rate for schools built before 1933 is 25 to 75 percent.

Perhaps the only other major drawback of the Field and Garrison Acts is that they do not apply to all educational facilities or other important public facilities (J.F. Meehan, oral commun., 1982). Universities, for example, are not subject to the acts. Hospitals were not placed under similar requirements until after the San Fernando earthquake in 1971. The Riley Act, which was also enacted in 1933, requires most other buildings to be constructed to comply with the state building code, but does not impose strict enforcement and review procedures as prescribed for schools by the Field Act. The review provision is probably primarily responsible for the Field Act's success. A study by Woodward-Clyde Consultants (1980a) concluded that "the superior performance demonstrated by public schools constructed under Field Act standards appears to be a product of both the formalized review process and the appropriateness of policy standards. The superior performance is also a product of the sound judgment exhibited by reviewers; this is related to sufficient scope of review, a high level of expertise of reviewers, and a high degree of independence of reviewers."

\section{HOSPITAL SEISMIC SAFETY ACT}

After many medical facilities were severely damaged during the San Fernando earthquake in 1972 (fig. 15), the Hospital Seismic Safety Act (California Health and Safety Code, beginning with section 15000) was enacted. This act requires enforcement and inspection procedures similar to those of the Field Act for construction and alteration of hospitals. New construction of hospitals must conform to provisions of the latest edition of the ICBO Uniform Building Code. An important difference from the Field Act is that the Hospital Seismic Safety Act requires, beyond protection of life and property from the immediate dangers posed by an earthquake, that hospitals be capable of continuing services to the public after a disaster. Additional requirements for fire safety and equipment anchorages are imposed. According to Woodward-Clyde Consultants (1980a), practical standards used to fulfill these requirements are that the design should permit safe exit after the maximum credible earthquake and continued function after the maximum probable earthquake (see app. B).

Implementation of the Hospital Seismic Safety Act is different than for the Field Act because of the additional safety requirements and because hospital con- struction is regulated by the Office of Statewide Health Planning and Development (SHPD). The Office of the State Architect, Department of General Services, reviews designs and inspects structures as under the Field Act, but under contract to SHPD, which coordinates all reviews and enforces the act. A Building Safety Board within SHPD serves as an advisory body and acts on appeals and waivers. To cover the cost of administering the act, SHPD is authorized to collect a filing fee not to exceed 0.7 percent of the estimated construction cost.

Construction plans for work that affects hospital structural elements must be accompanied by a geologicand engineering-investigation report that evaluates the potential for earthquake damage. This site assessment can be waived by SHPD if judged unnecessary and not beneficial to public safety. The Department of General Services (generally the State Architect) provides independent review of the geologic data by a registered engineering geologist or DMG as part of its basis for approving or rejecting the plans.

The Hospital Seismic Safety Act authorizes SHPD to review hospital operations to ensure that the hospital is adequately prepared to resist earthquake damage. The act does not specifically provide for inspection of structural elements, nor does it require upgrading of older hospitals that are seismically hazardous. Amendments to the act (chapter 303,1982 ) authorize SHPD to inspect any hospital for hazardous conditions and order it vacated if it violates applicable building standards. Although upgrade policies that affect hospitals may also be contained in general plans and implemented at the local level, very little local action has been taken (Woodward-Clyde Consultants, 1980a).

Besides lacking policy for upgrading existing hospitals, the Hospital Seismic Safety Act has a potentially serious limitation regarding the requirement for continuing hospital services after an earthquake. The ability to provide uninterrupted medical services strongly depends on lifelines and other external critical facilities, such as roads, electric power, natural-gas lines, water, and sewer. Seismic-safety requirements for these facilities do not exist to the degree imposed on hospital buildings under the act. It is questionable whether a hospital could continue to function for a long period after a major earthquake that would probably disrupt some or all of these services, even though the building conforms to the strictest earthquake-safety standards. Although the Veteran's Administration requires its hospitals to be capable of operating independently of external facilities for at least 4 days, no similar requirement is included in California's Hospital Seismic Safety Act (Woodward-Clyde Consultants, 1980a).

\section{RILEY ACT}

The Riley Act (Health and Safety Code, secs. 19100 to 19183) regulates construction of most other buildings in California that are designed for human occupancy and do not have their own specific legislation. The only exclusions are buildings located outside city limits and 


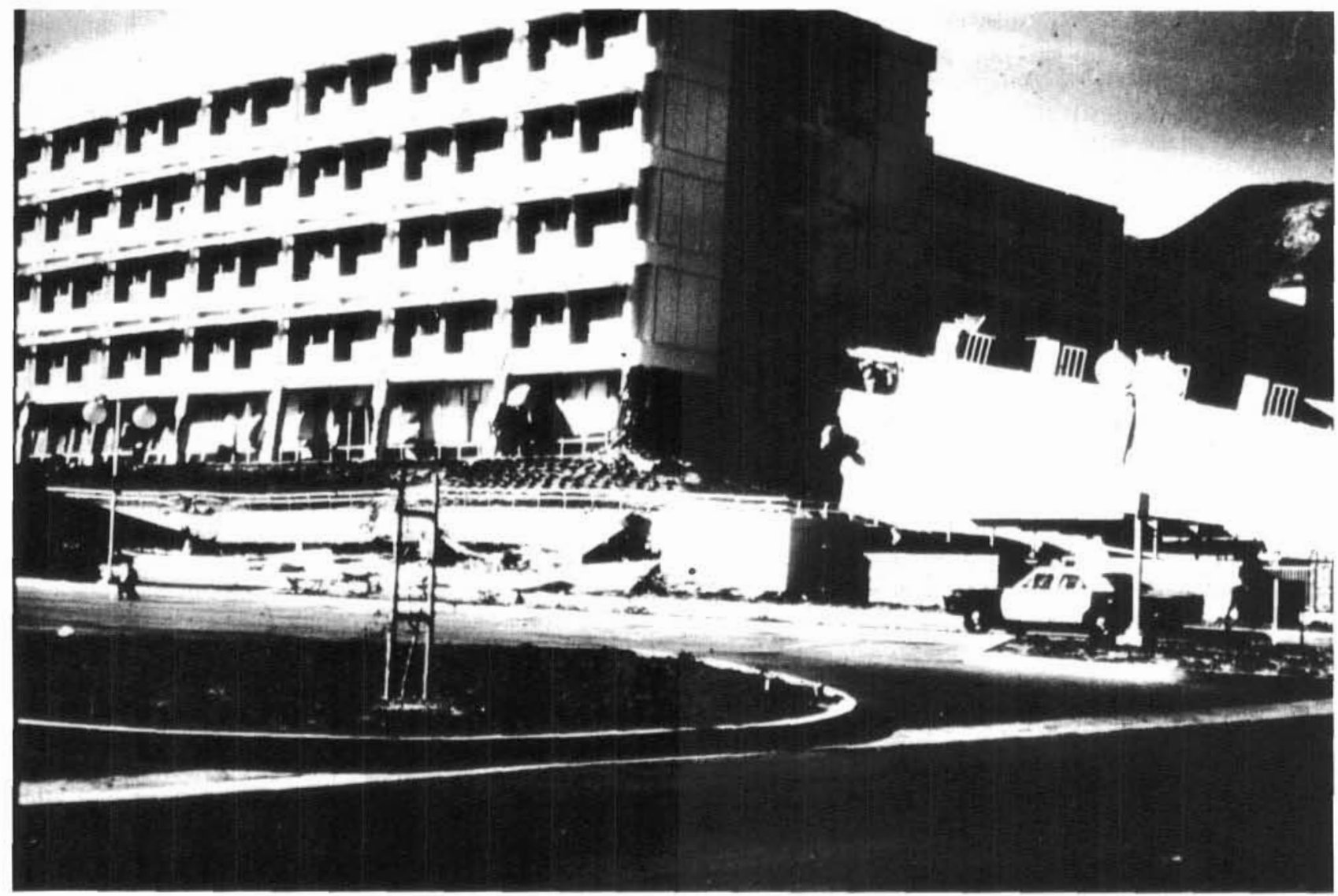

Figure 15. Olive View Hospital, Sylmar, California, damaged by the San Fernando earthquake on February 9,1971 (Richter magnitude 6.4). Photograph courtesy of National Oceanic and Atmospheric Administration.

not intended for human occupancy, one- and two-family dwellings outside city limits, farm buildings, and certain labor-camp buildings in unincorporated areas.

The Riley Act was signed into law in 1933 and originally required that all buildings, other than those listed above, be constructed to withstand lateral design-wind and earthquake forces of 2 to 3 percent of the total vertical design load. Amendments in 1965 and 1974 changed the lateral-force requirements to comply with the state building code (part 1, title 24, California Administrative Code), which is based on the latest edition of the ICBO Uniform Building Code. A 1979 amendment allows local governments to assess the earthquake safety of existing buildings and identify permissible corrective actions. Structures governed by the Field, Garrison, or Hospital Seismic Safety Acts and all state-owned buildings are specifically excluded from the 1979 provisions. The latest amendment in 1980 authorizes local governments to require installation of earthquake-sensitive gas-shutoff valves in public buildings as a fire deterrent.

Although design and construction standards for buildings under the Riley Act are similar to standards of the Field and Hospital Acts (all use the ICBO Uniform
Building Code), review and enforcement requirements are not nearly as stringent. City and county governments are responsible for enforcing new construction under the Riley Act through their own ordinances and procedures, some of which are prescribed by the Uniform Building Code. The 1979 amendments for reconstruction of hazardous buildings authorize local governments to assess earthquake safety and establish reconstruction standards. This provision applies only to unreinforced masonry buildings constructed before building codes were adopted that require earthquake-resistant design; in effect, the Riley Act assumes that all newer buildings are safe.

Two important provisions alleviate major concerns of local governments that want to initiate programs for building rehabilitation. One provision grants local governments immunity from liability for earthquake damage based on any action taken or not taken to assess or upgrade old buildings. The other provision recognizes the high cost of rehabilitating old buildings to meet codes that must be met for new buildings and allows local governments to enact their own building standards to improve seismic safety and still be economically feasible. 
Because the Riley Act does not require centralized review and therefore has not produced centralized records, its effect in reducing earthquake hazards to buildings in California is difficult to assess. The present concern over the earthquake safety of many buildings constructed in California before and after 1933 suggests that the Riley Act has not been entirely successful. Although the act is enforced by local agencies, the quality of review and inspection varies (Woodward-Cly de Consultants, 1980b). Contributing factors include qualifications of building officials, competence of inspectors, personnel and funding limitations, interpretation of the building code, and familiarity of the building official with the type of project involved. Building officials in California are not required to meet any standard minimum qualifications. According to the Woodward-Clyde study, many building officials assume that building designs, soil reports, and geologic-hazard reports are adequate because they are prepared by registered professionals who are familiar with the code's requirements. Funding limitations often prevent local agencies from hiring competent professionals to perform reviews and from contracting to have reviews performed externally.

Elected local officials play a large role in determining the degree of building-code enforcement by establishing budgets and setting work priorities. One survey of local building departments showed that 40 percent of the respondents believed that their elected local officials are sympathetic to weaker enforcement of building regulations, and 70 percent felt that localgovernment management has little or no concern about earthquake risk (Olson and Scott, 1980: International Conference of Building Officials, 1980). The survey concludes that roughly half of the local building departments in California operate with little support from elected officials and management. Judging from these surveys, the attitudes of many local elected officials in California apparently do not reflect public concerns for seismic: safety. Two recent surveys in California showed strong public support for stringent seismic-safety measures. In one survey (Turner and others, 1979), 65 percent of the respondents strongly favored public expenditures to enforce building codes for seismic safety. The second survey ('Turner and others, 1980) showed that 75 to 80 percent of the respondents favored laws to strengthen or vacate hazardous buildings.

\section{DAM SAFETY ACT}

Design, construction, alteration, operation, and removal of nearly all nonfederal dams in California (concrete and earth-fill) are under the authority of the Dam Safety Act (California Water Code, secs. 6000 to 6501). The only exemptions are dams smaller than the jurisdictional size specified by the act. based on height and storage capacity. The Dam Safety Act is another example of response to public reaction that followed a major disaster. In 1928, the St. Francis Dam in southern California failed and caused extensive property damage and about 120 deaths. The new law put all nonfederal dams under state supervision if they were built or proposed to be built across a natural watercourse. State involvement includes extensive reviews of design and construction elements to ensure safety. After the 1963 failure of the Baldwin Hills Dam in Los Angeles, which was not built across a natural watercourse and therefore was exempt from state supervision, the act was amended to include offstream dams.

The Division of Safety of Dams (DSD) in California's Department of Water Resources (DWR) administers the Dam Safety $\Lambda \mathrm{ct}$ and is required to authorize and supervise all aspects of dam construction, alteration, operation, and removal. Not only does DSI) perform these functions for state-jurisdictional dams; it also reviews federal hydroelectric and flood-control dams under the Memoranda of Understanding with the Federal Energy Regulatory Commission and the U.S. Army Corps of Engineers.

For state-jurisdictional dams, the Dam Safety Act and associated regulations require state-of-the-art design and construction standards. Before construction can begin, an application must be filed with DWR, accompanied by detailed design plans, specifications, and the results and supporting data from regional and sitespecific geologic and engineering studies. The DSD conducts extensive geologic and engineering reviews and sometimes retains outside consultants to assist with the review of major critical projects. As part of the review process. DSD may conduct site inspections and observe field studies.

Dam construction or alteration may begin after DSI formally approves the design plans and supporting data. To ensure that approved plans are followed and unforeseen problems are recognized and resolved, DSD frequently inspects sites during construction and reviews the required owner-performed inspections and tests. After the dam is built, a use permit is required before the reservoir can be filled. After filling, the dam and reservoir are inspected and evaluated at least annually during operation. The use permit can be revoked at any time if DSD finds a condition that indicates the dam or reservoir is unsafe and constitutes a danger to life and property. Fees that are collected with the initial application (before the design review begins) and annually during the operational phase provide $\$ 200,000$ to $\$ 300,000$ to the state general fund each year to partially offset costs of the dam-safety program.

The JWR is also responsible for site selection, design, construction, operation, and maintenance of State Water Project facilities. A Consulting Board for Earthquake Analysis was established to assist DWR in seismic design and participate with DSD in design reviews. The DSD annually inspects and evaluates state dams and nonstate-owned jurisdictional dams; the consulting board conducts an extensive review every 3 to 
$5 \mathrm{yr}$. $\Lambda \mathrm{s}$ part of the safety program for state-owned dams, DWR also installs and operates strong-motion instruments to monitor earthquake effects. One or more instruments is installed on or near each dam at sites recommended by the design engineers for maximizing structural response. These data are combined with data from instruments not owned by the state to determine possible damage to existing dams and provide seismicdesign information for future dams. The instrumentation program is conducted by the Earthquake Engineering Section of DSD and is funded entirely through state water-use fees. Seismic instrumentation of dam sites has provided some of the best strong-motion data available any where for recent earthquakes.

The DWR requires high performance standards for dams, although design standards are not fixed. This approach promotes improvements in design techniques as technical knowledge improves. Each selected design must meet established minimum performance standards that are more conservative than for most other types of structures. For example, the design must ensure that no major amount of water is released from a reservoir as a result of the maximum credible earthquake or the 1,000-yr flood. The Dam Safety $\Lambda \mathrm{ct}$ makes the owner and operator of a dam or reservoir legally responsible for the dam's safety and specifically protects the state from liability for damages that result from failure after approval, enforcement of orders, regulation, or measures taken to prevent failure (W.W. Peak, oral commun., 1982).

As with the Field and Hospital Acts, success of the amended Dam Safety Act in reducing geologic and seismic hazards to dams and reservoirs is largely attributed to its strict, centralized review procedure. The approach to dam reviews, however, is much different because of the size and uniqueness of dam projects. In contrast to schools and hospitals, for which definite design codes must be followed and standard, proven designs are typically used, each dam presents totally new problems for which great flexibility in design must be allowed. For this reason, dam-safety reviews require expertise in several disciplines and a high level of independent thinking (Scott, 1981). Thus, DWR uses experienced staff as well as private firms contracted for external reviews. Geologists and engineers in DWR must meet minimum qualifications and participate in continuous technical training, including extensive educational programs in earthquake engineering. Many review tasks of the department are performed by reputable private consulting firms with the best expertise in their fields. The review processes of DWR are considered to be objective, independent, and thorough (WoodwardClyde Consultants, 1980b).

Although dams and reservoirs are subject to strict hazards-safety regulations under the Dam Safety Act, other elements of the water-supply system are almost totally unregulated with regard to geologic hazards. Most water-distribution facilities, including aqueducts, pumping stations, treatment facilities, and local distribution networks, are built and operated by municipalities and are generally self regulating. The remainder, serving 20 to 25 percent of California's population, are owned by private companies regulated by the Public Utilities Commission. However, there are no general policies regarding protection of these facilities from natural hazards (Woodward.Cly de Consultants, 1980a). Because aqueducts and water-distribution lines frequently must. be placed across active faults or within sediments subject to failure during earthquakes, they are highly susceptible to damage. Possible serious effects of damage, as demonstrated during past earthquakes, include loss of adequate water supply for fighting fires, contamination from damaged sewage facilities, and disruption of water supply to medical facilities for treating disaster victims. Except for the Dam Safety Act. there are no state policies regarding protection of water-supply facilities from natural hazards (W.W. Peak, oral commun., 1982).

The dam-safety program in California has not only been a model for other states, but has also had a major impact on federal dam-safety programs. Because of its major recent influence in the federal $\Lambda$ uburn Dam and Warm Springs Dam projects, California helped demonstrate the inadequacy of the review process for many federal dam projects and was instrumental in causing improvements at the federal level (W.W. Peak, oral commun., 1982).

Just as the hazards-mitigation policies of the Field and Hospital Acts could be expanded to improve the safety of other buildings for public occupancy for which similar policies do not exist, the Dam Safety Act could be applied to other critical facilities in California and elsewhere. Presently, California does not have a formal review process for other critical facilities, although the Seismic Safety Commission has strongly encouraged such review. The SSC defines a critical facility as "any structure housing or serving large numbers of people, or otherwise posing unusually high hazards to public health and safety in the event of damage or malfunction" (Scott, 1981). In addition to dams, schools, and hospitals, the definition includes nuclear reactors, liquifiednatural-gas terminals, petroleum-storage facilities, fire and police stations, disaster centers, communication and transportation facilities, utility lifelines, electric generating plants, prisons, coliseums, and large office buildings.

\section{STRONG-MOTION INSTRUMENTATION PROGRAM}

Technology for design of earthquake-resistant buildings is derived largely from information about the forces and deformation induced in structures by ground motion during earthquakes. Reliable information of this type can be obtained only by measuring motion in 
buildings and on nearby ground during earthquakes. Lack of such data continues to hamper advancement of earthquake-design technology, despite major nationwide expansions in strong-motion instrumentation. The 1964 Great Alaska Earthquake produced limited information useful for seismic design because there were no strongmotion instruments in the area to record ground motion and building response.

In addition to providing data essential for improving earthquake-resistant design, quantitative measurements of ground motion are important to develop a better understanding of earthquake processes, improve prediction capabilities, aid regional planning, and assess applicability of data to other areas.

Because strong-motion data are important for improving earthquake-resistant design, a requirement was added to the Uniform Building Code in the mid1960 s that all buildings with more than six floors be instrumented with strong-motion-recording devices. Many California cities immediately adopted the provision. However, problems and inadequacies soon became apparent. There generally were no provisions for continued instrument maintenance, many areas were neglected because instruments were concentrated in areas of high-rise buildings, and instrument locations prescribed by the code frequently proved inadequate. For example, during the 1971 San Fernando earthquake, all deaths occurred in buildings with fewer than six stories, and instruments located at sites in buildings as prescribed by the code (one at ground level, one on a middle floor, and one at the top) often produced unusable data because the effects of structural details and resonant properties of the buildings were not considered. The ground-level instrument produced no buildingresponse data, and the instrument on the middle floor often was located at a nodal point where response was minimal. The highest instrument often produced the only usable data, but recorded only the horizontal components of motion (California Division of Mines and Geology, 1976).

The California Legislature recognized the need for statewide planning, coordination, and standardization to obtain quantitative ground-motion information from earthquakes. The Strong-motion Instrumentation Program (SMIP) (Public Resources Code, secs. 2700 to 2708 ) was signed into law in October 1971, with the objective of "acquiring strong-motion instruments and installing and maintaining such instruments as needed in representative geologic environments and structures throughout the state." The Division of Mines and Geology is responsible for organizing and monitoring the SMIP with advice from the Seismic Safety Commission. Under the program, DMG purchases, installs, and maintains instruments throughout the state and processes the resulting data. Funds to operate SMIP come from an application fee levied on all building permits in the state. The fee, collected by cities and counties, is 0.007 percent $(\$ 0.07$ per $\$ 1,000)$ of the proposed facility's total value as determined by the local building official.
Local governments deposit the collected fees in the Strong-Motion Instrumentation Special Fund of the State Treasury to be used exclusively for the program. A city or county may be exempted from collecting the fees if it has adopted an ordinance that requires accelerograph installation and has at least one building under its jurisdiction that was instrumented in accordance with the ordinance before January 20, 1972. Fees are not collected from projects that do not require a city or county permit. Thus, state and federal construction projects and those requiring only state or federal permits are exempt from the fee requirement.

The SMIP is funded entirely by fees collected by cities and counties, including instrument purchases, field logistics for installation and maintenance, salaries, and data processing. Because the budget is affected directly by the construction industry, it varies from year to year. The program is adjusted to respond to revenue fluctuations; for example, the number of instruments purchased and installed each year is increased or decreased. The overall financial health of the program has been excellent despite downturns in the construction industry because fees have generated more revenue than originally anticipated. Although annual revenue was initially projected at $\$ 250,000$, it grew rapidly to well over $\$ 400,000$ in the first few years and is now about $\$ 1$ million per yr (California Division of Mines and Geology, 1976; T.M. Wootton, oral commun., 1982). Although additional funds were needed for unanticipated data processing and instrument maintenance, the purchase and installation of instruments were accelerated. The program's goal is to instail 1864 accelerographs by the year 2035, at which time the building-permit fee will be reduced to a level sufficient to maintain a monitoring program. Instruments will be distributed equally among free-field sites (away from man-made structures), buildings, structures other than buildings, and utility systems (T.M. Wootton, oral commun., 1982).

The SMIP uses structural information available for a building and its location relative to faults when it installs accelerographs and recording systems rather than using the standard minimum installation prescribed by the Uniform Building Code. This procedure maximizes the results by anticipating the building response. Most installations have a 13-channel capability that can record up to four strategically placed instruments that measure three directional components.

Data generated in the SMIP are being used to improve building designs and update codes. For example, one instrumented building that was constructed in compliance with existing codes failed during the 1979 Imperial Valley earthquake. Because the accelerographs recorded the earthquake motion and failure of the building, they provided invaluable data to analyze the building's structural response and determine design flaws responsible for failure (T.M. Wootton, oral commun., 1982).

Many local programs do not comply with the standards of the state program because of the exemption 
granted to cities and countries that had adopted pre1972 ordinances that required installation of accelerographs. Those that had adopted a program were using unreliable building locations prescribed by the Uniform Building Code. Unfortunately, the exemption applies to most major cities. To partially alleviate this problem, the legislature enacted an amendment in 1975 that allowed, but did not require, an exempted city or county to apply to rescind its exemption.

Another possible weakness with the SMIP is that many major or critical facilities that require state or federal rather than local permits are exempt from the program. This situation does not necessarily mean that state- and federal-regulated critical facilities are not being adequately instrumented, but it may mean that some are not financially supporting a program from which they benefit greatly. A few of these facilities, such as dams in the State Water Project, are instrumented under separate programs with their own sources of funds and are contributing to the strong-motion data base in California. The earlier Advisory Board to the SMIP (now replaced by the Seismic Safety Commission as advisory body to the program) solicited the input of the California Water and Power Earthquake Engineering Forum and the Public Utilities Commission to determine appropriate accelerograph installations for many critical facilities and lifelines systems. The SMIP has since included many of these structures in its instaliation program (T.M. Wootton., oral commun., 1982).

A third potential weakness is the possible lack of sufficient funds to process and interpret strong-motion records from a major earthquake, a contingency not addressed in the legislation. In the absence of a legislative solution, the Office of Strong-motion Studies has proposed two ways to deal with this problem. First, the program has a continuous reserve of controllable funds to purchase and install new instruments; these funds could be diverted, if needed, after a major earthquake. Second, after planned installations are completed and the program enters its operational phase, revenues will exceed expenses and thus allow a contingency reserve to accumulate. Once an adequate reserve is attained, fees could be reduced to a level necessary for program maintenance (California Division of Mines and Geology, 1976).

\section{O'THER PROGRAMS IN CALIFORNIA}

In 1975, a Surface Mining and Reclamation Act (SMARA) was enacted in California to prevent adverse environmental impacts of surface mining, restore mined areas to a condition compatible with other uses, balance mining interests against other land uses, and eliminate residual hazards to public safety. The SMARA requires the State Mining and Geology Board to develop policies and guidelines for reclamation of mined land, which then must be implemented by lead agencies (generally local governments). The State Geologist is required by
SMARA to classify areas based on their mineral potential (areas that contain little or no mineral deposits, areas that contain significant mineral deposits, and areas that contain mineral deposits of unknown significance). This information is used by SMGB to establish policies and land-use priorities for mineral-resource areas. Local governments are required to balance land use between development and resource extraction and to issue surface-mining permits consistent with SMGB policies.

A reclamation plan must be submitted to the local agency before a permit can be issued. Potential geologic hazards that result from surface-mining and reclamation practices represent one of several issues that must be addressed by the plan. Proposed approaches to soilerosion control, flood control, disposal of mine waste, slope gradients, backfilling, erosion, and drainage must be described in the plan and must be consistent with SMGB policies before a permit is issued. The plan is reviewed only by the local agency. $\Lambda$ copy of the plan must be submitted to the California Division of Mines and Geology, but DMG does not have approval authority. 'The SMGB encourages local agencies to integrate the requirements of $S M A R A$ with other required planning and review procedures, such as the general plan (California Division of Mines and Geology, 1979).

Another statute that requires Iocal-government action in land use and development is the California Envirommental Quality Act of 1970 (CEQ $\Lambda$ ). This law requires local agencies to review, for environmental effects, all public and private projects over which they have discretionary authority. State guidelines for implementation specifically include geologic and seismic hazards as environmental effects and direct local agencies to examine such hazards in their assessments. Any issue in the assessment that may have a significant effect. including exposing people or structures to major geologic hazards, must be addressed in an environmentalimpact report. For many new (ritical facilities that do not carry their own review requirements (as for dams and hospitals), CEQA is the chief means to ensure that geologic and seismic hazards are considered in siting and design (Mintier and Stromberg, 1982).

The Subdivision Map Act (1907) is the oldest land-use law in California. Among other provisions that establish procedures for filing and approval of parcel maps, this law requires studies to evaluate possible expansive soils and flood hazards in tract developments of five or more lots, unless waived by the local building official. These studies can provide the developer and local building official with information necessary to take proper precautions against soil and flood hazards. The California Division of Real Estate may refuse approval if a subdivision is threatened by floods. As with implementation of the general plan and Riley Act, the Subdivision Map Act relies on diligence, adequate funding, and competence of local officials to be successful. Expansive soil is one of the most costly geologic problems nationwide but, ironically, one of the easiest and 
cheapest to correct. The benefit-cost ratio of measures to reduce losses from expansive soils can be as high as 20:1 (Alfors and others, 1973). This hazard can be dealt with adequately at the local level, such as through the Subdivision Map Act.

In 1981, an Earthquake Education Act signed into law in California provided $\$ 250,000$ to develop publiceducation programs about earthquake preparedness and response. The Seismic Safety Commission was required to develop these programs within $2 \mathrm{yr}$, then test the programs in communities and schools in several counties. In 1984, a law was passed that authorizes the statewide implementation of the new curriculum. Another 1984 law requires all California schools that have an enrollment of 50 or more students to develop earthquake disaster plans and conduct regular drills.

In 1981, a Mobile Home Safety Act was passed that requires state certification of anchoring devices for mobile homes. Manufacturers of the devices must submit results of physical tests of their products for review by the Department of Housing and Community Develop. ment and demonstrate that they meet minimum engineering standards for earthquake safety.

\section{SATUTORY AUTHORITY FOR CALIFORNIA AGENCIES ENGAGED IN GEOLOGIC. HAZARD MITIGATION}

All hazards programs in California are administered by a state agency, although for many programs the enforcement power is largely delegated to local governments. Agencies that have wide-ranging responsibilities for geologic-hazards mitigation are the Division of Mines and Geology (DM( $)$, the State Mining and Geology Board (SMGB), and the Seismic Safety Commission (SSC). In broad terms, SSC is an advisory body and SMGB a policy-setting body. The DMG collects, analyzes, and disseminates information on the state's geology according to SMGB policies and (for earthquake issues) the advice of the SSC. Many other agencies are involved in hazard-mitigation programs but have narrower responsibilities. The roles of these agencies, such as the Office of Planning and Research, Office of the State Architect, and Division of Safety of Dams, are described in preceding sections on statutory programs.

\section{Division of Mines and Geology}

Sections 607 and 2201 to 2205 of the Public Resources Code established the Division of Mines and Geology under the direction of the State Geologist and outlined its authority. With regard to hazards. "the State Geologist may...conduct, with city and county governments or federal agencies, large-scale geological investigations to identify and provide timely delineation of geological hazards in and adjacent to metropolitan areas..."(sec. 2205h). Within this authority, DMG routinely studies geologic hazards throughout the state and publishes the results in bulletins, special reports, county reports, and maps for use by local governments and the general public.

Other statutes require DMG to perform specific additional functions. For example, the Strong-motion Instrumentation Program was established by separate legislation that requires DMG to organize and monitor the program. The Alquist-Priolo Special Studies Zones Act requires DMG to delineate special-studies zones that encompass potentially active faults. Mineral-resource zones must be delineated by DMG (under the surface Mining and Reclamation Act) to set priorities and policies for balancing local land use and developing reclamation plans. State planning law requires local agencies to submit copies of their approved general plans to DMG; for review.

Most funding for DMG activities comes from yearly appropriations by the legislature through the general fund. The funds designated for the Strong-motion Instrumentation Program are directly offset by localgovernment deposits to the SMIP Special Fund from permit fees. Otherwise, appropriations to DMc; are not itemized by project except for occasional special projects ('T.E. Gay, oral commun., 1982) The State Geologist manages the budget to conduct programs under authority granted to DMG and according to policies and priorities set by SMGB. The Urban Geology Master Plan for California (Alfors and others, 1973) was prepared using funds from the Department of Housing and Urban Development.

\section{State Mining and Geology Board}

The State Mining and Geology Board has existed in some form as an advisory body for state geologic issues since the $1880 \mathrm{~s}$. It evolved into an informal policy board for the Division of Mines and Geology until 1975, when the legislature gave the board specific policy-setting duties in the Surface Mining and Reclamation Act. Complementary legislation in 1975 (secs. 660 to 678 of the Public Resources Code) formally established SMGB as a policy-making body for DMG and set its overall statutory authority.

The SMGB consists of nine members who represent the public interest; they are appointed by the Governor and are not employed by the state. Minimum qualifications of members are set by statute and are intended to represent a broad range of technical and planning fields that include geology, mining engineering, soils engineering, seismology, mineral resources, ecology, landscape architecture, and local government. $\Lambda$ chairman is appointed by the Governor from among the members, and a paid executive officer and staff are appointed by the board. Board members hold staggered 4-yr terms and receive $\$ 100$ compensation for each day the member is engaged in official board duties (up to $\$ 4,000$ per yr).

In addition to developing surface-mining and reclamation policy, $S M G B$ "shall also represent the 
state's interest in the development of geological information necessary to the understanding and utilization of the state's terrain and seismological and geological information pertaining to earthquake and other geological hazards. General policies for the Division shall be determined by the Board." The SMGB nominates a candidate for State Geologist, who is appointed by the director of the Department of Conservation and administers the board's policies as chief of the Division of Mines and Geology.

In effect. SMCBB assumes much of the load usually borne by state legislatures and administration in setting policies and priorities for the activities of a state geological survey (D.W. Sprague, oral commun., 1982). The advantage is direct public influence on survey activities by independent public representatives. The possible disadvantages are the additional "layer of bureaucracy, a working relationship that may hamstring the survey, and difficulties identifying which policy issues are appropriate for board action as opposed to those that can be effectively resolved within the survey. There is also a potential problem regarding division of responsibilities in earthquake-hazard issues between SMGB and the Seismic Safety Commission. Although SSC has an advisory role and SMGB has a policy-setting role, the difference is often not distinct; whether two separate bodies are justified where subject areas overlap is questionable. (On issues related to seismic: hazards, however, SMGB and SSC appear to cooperate on an informal basis to minimize duplication. In at least one instance, legislation has formally established $\mathrm{SSC}$ as a policy-setting body for a DMG function. In 1975, the legislature abolished a separate board formerly established for the Strong-motion Instrumentation Program and transferred advisory and policy authority to SSC. The SMGB no longer issues policy for DMG management of the strong-motion program.

\section{Seismic Safety Commission}

The Seismic Safety Commission (SSC), established by the California Legislature in 1974, was an outgrowth of two advisory groups that were active in earthquakerelated issues. The legislature's Joint Committee on Seismic Safety (1969-74) and the Governor's Earthquake Council (1971-74) recommended formation of a permanent organization with hroad powers in earth. quake-hazard reduction. The SSC was established by sections 8890 to 8899.5 of the Government Code as an advisory body to coordinate the various earthquake. related programs of state, federal, and local agencies. Amendments to the Seismic Safety Commission Act in 1976 abolished the Strong-motion Instrumentation Board and Geological Hazards Technical Advisory Committee and transferred their functions to $\mathrm{SSC}$. In 1984 , the legislature removed the sunset clause on SSC's enabling legislation, effectively making SSC a permanent commission.

All but two of the 17 members of SSC are appointed from the public by the Governor to represent the fields of seismology, geology, soils engineering, structural engineering, architecture, fire protection, public utilities. mechanical engineering, city and county government, insurance. social service, and emergency service. One member is appointed from the State Senate and one from the State Assembly. Members have staggered $4 \cdot \mathrm{yr}$ terms and receive only travel expenses and per diem for their work. The SSC appoints a paid executive director who hires technical and clerical staff. Total funds expended by SSC in FY 198()-81 were $\$ 396,569$, of which $\$ 31,000$ was for direct support of $\mathrm{SSC}$ and the remainder for contracts and staff support to conduct special projects and prepare reports (California Seismic Safety Commission, 1981).

Responsibilities and powers of SSC are diverse, but are basically restricted to earthquake-hazard-reduction issues. Its statutory mandates are to set goals and priorities in the public and private sectors: recommend program changes to state and local agencies and the private sector to reduce earthquake hazards; review postearthquake reconstruction practices; gather, analyze, and disseminate information; encourage research; sponsor training for enforcement and technical personnel; help coordinate seismic-safety activities of all levels of government; advise the State Mining and Geology Board on seismic'safety aspects of the Special Studies Zones Act; and advise the State Geologist on the Strong-motion Instrumentation Program. To carry out its functions. SSC reviews proposals, drafts legislation, conducts public hearings, and enters into contracts for special studies as a basis for issuing its recommendations. Much of SSC's work is performed by or under supervision of specially appointed task committees. Figure 16 summarizes the functions of SSC and illustrates its relationships to the Division of Mines and Geology, the State Mining and Geology Board, and other agencies.

In practice, SSC helps coordinate about 30 seismicsafety programs that invoive 52 state agencies. T'otal program expenditures during the past few years range from about $\$ 13.7$ million in FY $1980-81$ to $\$ 18.1$ million in FY 1978-79. In addition to its ongoing advisory and coordinating functions, SSC reviewed numerous programs, such as the Hospital Seismic Safety $\Lambda c t$, Field and Garrison Acts, and seismic-safety-element requirement (General Plan) and, as a result, recom. mended changes and drafted legislative amendments to increase their effectiveness. The SSC was instrumental in initiating state review of the federal Auburn Dam and Warm Springs Dam projects and establishing memoranda of understanding with federal agencies for future dam reviews (California Seismic Safety Commission, 1981).

After damaging earthquakes in California, members of SSC or its staff generally visit the site to observe the damage, evaluate disaster response, and issue recommendations for policy or program changes for particular problems made apparent by the events. Because of high public concern over the Livermore Valley earthquake of January 1980 and its possible implications for seismic safety of plutonium facilities at the Lawrence Livermore 


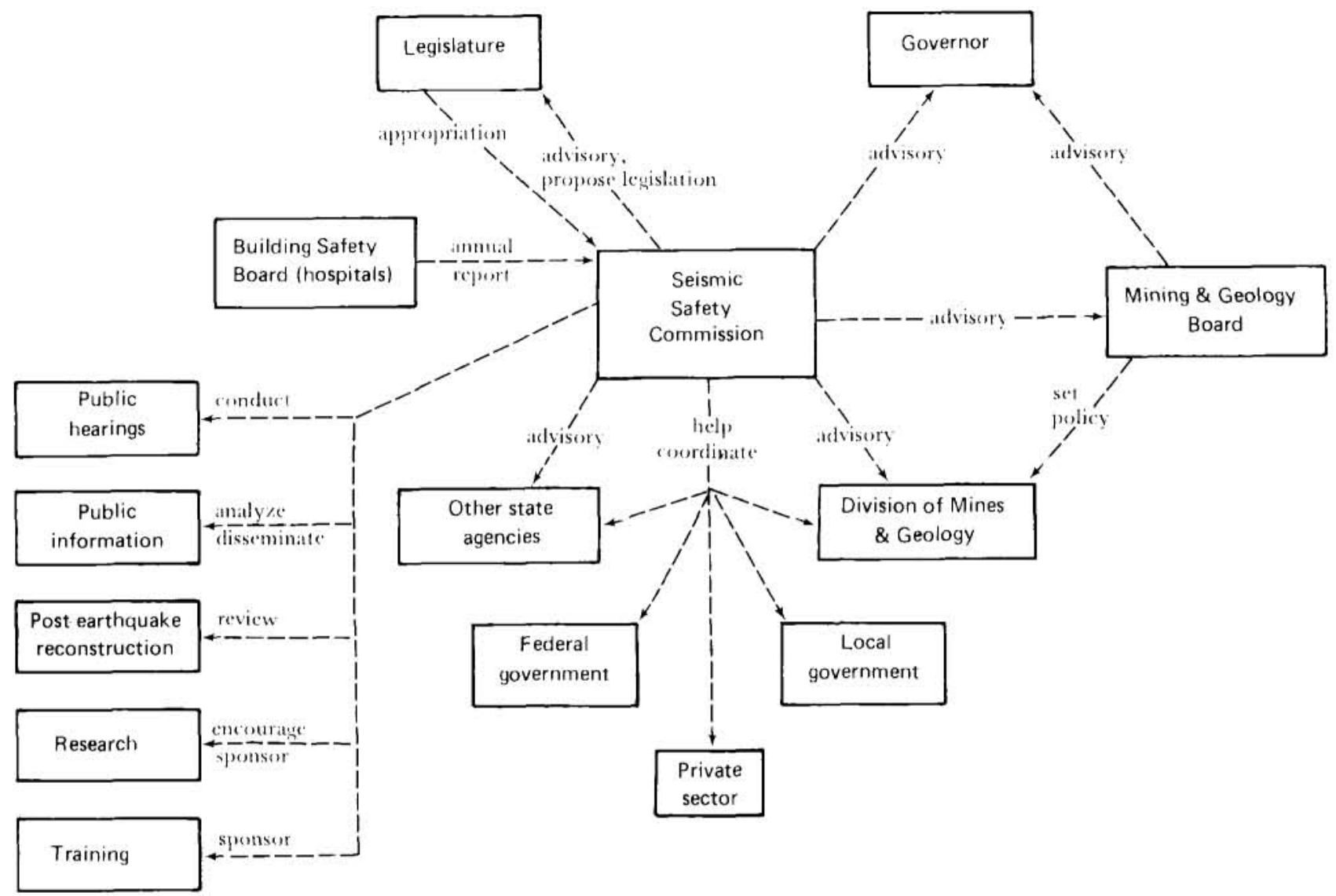

Figure 16. Functional relationships between the Seismic Safety Commission and other organizations and activities in California.

Laboratories, SSC conducted public hearings and initiated an independent review of the facility.

Recently, SSC created a Hazardous Buildings Committee to develop a model local ordinance for hazards mitigation of older buildings and recommended that seismic safety of state-owned buildings be evaluated. The Southern California Earthquake Preparedness Program (SCEPP) is a significant cooperative program with local government. The program is funded by the state and federal governments and involves five southern California counties. The objectives of SCEPP are to produce an operational prediction and warning system, establish earthquake-hazard-reduction plans, develop public-awareness programs, assess earthquake vulnerability, and conduct tests to improve plans and systems. The SSC has overall management responsibility for SCEPP and has appointed a policy advisory board to provide project direction. In 1984, the legislature authorized funding to extend SCEPP and initiate a similar program in the San Francisco Bay area (R.A. Andrews, oral commun., 1984).

A formal coordinating and advisory body for nonearthquake-related hazards does not exist in California. The SSC has reviewed some statutory programs and their implementation problems, but has focused primarity on earthquake-related issues. Legislation that established SCEPP in 1980 also broadened the authority of SSC to all natural hazards, but the demands of earthquake-hazards work have prevented the commission from devoting significant effort to other hazards. The State Mining and Geology Board provides policy and advice to the Division of Mines and Geology on other hazards, but not to other state agencies and only in a limited fashion to local governments (D.W. Sprague, oral commun., 1982).

\section{STATE BOARD OF REGISTRATION FOR GEOLOGISTS AND GEOPHYSICISTS}

A State Board of Registration for Geologists and Geophysicists is responsible for examining and registering applicants who perform professional geological or geophysical work in California. Originally established for registration of geologists only, the board was created through legislation in 1968 (secs. 7800 to 7807 , California Business and Professions Code) because of considerable problems that developed when unqualified persons performed geologic work required by various local 
agencies. In the early $1960 \mathrm{~s}$, city and county governments began adopting ordinances that required geologic reports in proposed subdivision areas where a geologic hazard was known or presumed to exist. The proliferation of such ordinances occurred after Los Angeles County lost a $\$ 6$ million lawsuit that resulted from movement of the Portuguese Bend landslide. The movement was initiated by construction of a county road (Campbell, 1976). The new ordinances created an immediate and considerable demand for geologists. Unfortunately, many unqualified people took advantage of the demand, which resulted in serious inadequacies and wide variation in report quality.

To protect homeowners and subdividers who were responsible for meeting report requirements, cities and counties established qualifying boards to determine who were qualified geologists and stipulated that only reports prepared by approved professionals would be acceptable. With separate boards in each jurisdiction, each with its own qualifying criteria, geologists were forced to take numerous examinations and pay fees to several boards to practice in different areas of the state. Eventually, geologists demanded action from the state.

In 1968, legislation created the Board of Registration for Geologists and set minimum qualification requirements. The board developed its own regulations to establish procedures and fees. In 1972 , the law was amended to include geophysicists, with similar requirements regarding background and experience. All geologi. cal or geophysical reports required under state and local laws must now be prepared by or under the supervision of a state-registered geologist or geophysicist. Optional certification in a specialty (such as engineering geology) is also provided under the statute.

Basic requirements for registration as a geologist are graduation with a major in geology or completion of at least 30 semester units in geologic science, of which at least 24 units are upper division or graduate courses; a minimum of $7 \mathrm{yr}$ of professional geologic work that includes at least $3 \mathrm{yr}$ under the supervision of a registered geologist or $5 \mathrm{yr}$ "in responsible charge of professional geological work"; and successful performance on a written examination. Credit is given for experience through undergraduate training ( $1-\mathrm{yr}$ credit for each year of training up to $2 \mathrm{yr}$ ), graduate training (year for year), and teaching (year for year if teaching load is at least six units per semester). Credit for training and teaching may not exceed 4 yr toward the 7 -yr requirement. Minimum qualifications for registration as a geophysicist are equivalent to those for a geologist.

The primary objectives of state-level professional registration of geologists and geophysicists are to protect the public from unqualified persons and provide comparable professional standards throughout the state (a benefit for the public and professionals). Some professionals also believe it has helped to establish comparable pay scales for engineering geologists and registered engineers.
The registration program in California has been subject to two major criticisms. First, registration does not necessarily protect the public from unqualified persons. Someone who once meets the qualifications for registration may not have the opportunity to keep up with rapid advances in knowledge and techniques in certain areas or maintain his or her original proficiency in that area. As an example, a city geologist in California found that "many |registered] geologists preparing reports are unaware of recent trends in fault analysis, rely on inappropriate methods of investigation, and restrict themselves too tightly to a site, referring only to published regional data rather than using field-checked air-photo interpretation" (California Seismic Safety Commission, 1977b). Inadequate report preparation by registered geologists and geophysicists is a significant problem, and only an adequate peer-review process is capable of detecting poor reports and producing improvements. When the Division of Mines and Geology reviewed geologic and seismic reports of a hospital site, only 31 of the initial 71 reports were accepted (Amimoto, 1974). The percentage of unacceptable reports has decreased markedly since the Division published study guidelines and the professional community became familiar with the requirements. However, many reports must still be revised. Apparently, the key to ensure acceptable geologic reports is a clear statement of the report requirements combined with an adequate review process. The requirement that the reports be prepared by registered geologists may not be necessary.

The second major criticism is that the law discriminates against academic personnel, who in many cases may be better qualified to perform certain types of work than many private consultants because they are more apt to keep up with new developments (Troxel, 1982). The law does not count research as qualifying experience, and many professors are not allowed by their employers to perform services that might be considered consulting. Because no more than $4-\mathrm{yr}$ credit can be granted for teaching and a professor can rarely accumulate more than 3-mo consulting experience each year, at least $16 \mathrm{yr}$ are needed to acquire the necessary experience.

\section{COLORADO}

Although there is less natural-hazards legislation in Colorado than in California, the Colorado state government and many local jurisdications are very active in hazard mitigation. Most activity is attributable to state land-use-planning laws, a subdivision law, and a state geological survey that is very active in hazard issues. Hazards are a major focus of state planning and subdivision laws that were developed in the early 1970s. During the 1960s, population growth in Colorado was tremendous, and new subdivisions were virtually unregulated. Development expanded from relatively safe, flat areas into narrow, flood-prone valleys and onto 
steep mountain slopes. Serious property damage from geologic processes in mountain subdivisions contributed to the overali problems of rapid development and short-lived land-sale schemes. These practices produced many unhappy customers and generated demands for stricter regulation of land use and development. Destruc:tive floods on the South Platte River in 1965 and 1969 reinforced the demand to consider geologic processes in land-use decisions.

Legislative action on land-use problems and geologic hazards began in 1969 when the Colorado Geological Survey (CGS) was established. In 1971, a land Use Commission was established and given broad advisory, coordination, and review responsibilities. $\Lambda$ stringent subdivision law |Senate bill (S.B.) 35 | that requires evaluation of geologic factors was enacted in 1972. Finally, two important statutes regulating local land use were passed in 1974: House bill (H.B.) 1034, a Local Government Land Use Control Enabling Act that authorizes cities and counties to consider geologic hazards in any land-use decisions; and H.B. 1011, an aet that concerns "areas and activities of state interest" and empowers local governments to designate geologichazard areas and requires that these areas be administered in accordance with state guidelines. Except for dam review and inspection. Colorado does not have statutory programs for state review and permitting of other special facilities as California has for schools and hospitals. Instead, the Colorado Land Use Commission has authority to review almost all development activities and issue cease-and-desist orders on behalf of the Governor for any development believed to pose a serious public hazard. The commission coordinates technical reviews among other state agencies, including the CGS, as part of its review function.

Unlike California, there is no state building code in Colorado, nor is there a state requirement for local adoption of building codes. Local governments have the authority to establish codes, and many have adopted the ICBO Uniform Building Code. The extent to which these jurisdictions adopt and implement provisions of the Uniform Building Code that relate to seismic and geologic hazards in Colorado was not studied.

\section{COLORADO LANI)-USE-PLANNING LAWS}

Colorado rities and counties did not acquire broad authority to plan and regulate land use until 1974, when the General Assembly passed the Local Government Land Use Control Enabling Act |H.B. 1034, Colorado Revised Statutes (Rev. Stat.) 29-20). The act also mentioned certain considerations, including geologic hazards, that could be used as a basis for land-use decisions. However, the act did not prescribe conditions, requirements, procedures, or schedules for adopting local land-use plans: its only intent was to grant land-use regulatory authority to local governments.
In a companion bill passed the same year (H.B. 1041, Colorado Rev. Stat, 24-65.1-101, and those that follow), local governments were given the authority to identify and designate 'matters of state interest' (activ. ities or areas having state significance), $\Lambda$ major category of 'areas of state interest' is natural-hazard areas, which could include geologic hazards, flood hazards, and wildfire hazards. Legal definitions were given for most of the nine specific geologic hazards: avalanches, landslides, rock falls, mudflows, unstable or potentially unstable slopes, seismic effects, radioactivity, ground subsidence, and expansive soil and rock. However, local designations are not restricted to these nine hazards.

House bill 1041 required the state lepartment of Local $A$ ffairs to conduct a statewide program to designate natural-hazard areas or other matters of state interest by June 1976. The General Assembly appro. priated enough money for the department to grant $\$ 25,000$ to each participating county. To qualify for the grant, the county had to designate flood-, wildfire-, and geologic-hazard areas, as well as other matters of state interest. In addition, the Colorado Land Use Commission is authorized to formally request local governments to designate matters considered by the commission to be of state interest. If the local government fails to act, the commission may seek court action. Although Iocal designation of matters of state interest is optional under the law, the state has considerable power to see that it is done. However, this power is limited because the courts make the final decision, presumably based on their judgment of whether an activity or area is important enough to the public welfare to warrant state involvement (P. Schmuck, oral commun., 1982).

Before a matter of state interest is designated, a local government must hold public hearings and submit the proposed designation to the Land Use Commission for review. Geologic-hazard designations are reviewed by the Colorado Geological Survey. Neither the CGS nor the commission have approval authority over local designations, but both may issue recommendations for revision, which the local government can either accept or reject. Once the designation is adopted, the local government must develop guidelines and regulations for its administration consistent with state criteria. Generally, guidelines for geologic-hazard areas are contained in local zoning ordinances. In H.B. 1041, state criteria for geologic-hazard areas specify that "all developments shall be engineered and administered in a manner that will minimize significant hazards to public health and safety or to property due to a geologic hazard." Additionally, H.B. 1041 requires CGS to develop model geologic-hazard-control regulations to serve as compulsory guidelines for local governments. The resulting publication (Rogers and others, 1974) provides definitions, descriptions, criteria for recognition, consequences of improper use, and mitigation procedures for each hazard, plus identification procedures, recommended 
professional qualifications for geologists and engineers who prepare reports, and suggestions to local governments for administering geologic-hazard areas. The appendix of the report contains a model geologic-hazardcontrol regulation that demonstrates application of suggested procedures. The CCis is also required by H.B. 1041 to provide technical assistance to local governments concerned with designation and development of guidelines for geologic-hazard areas (W.P. Rogers, oral commun., 1982).

After a matter of state interest, such as a geologichazard area, has been designated by a local government or after the Land Use Commission has formally requested that a local government issue a designation, no development is allowed in the area until local guidelines and regulations for its administration have been developed and approved. The law specifies that, as part of its administration, a local government must require a permit for any development in a designated hazard area. $\Lambda$ permit can be approved only if the proposed activity complies with local-government guidelines for administration of the area.

A model local geologic-hazard-area regulation developed by the Colorado Land Use Commission and the CGS (Colorado Land Use Commission, 1976) specifies acceptable hazard-mitigation techniques for issuing a permit in a designated geologic-hazard area. For example, in designated avalanche areas, structures that support snow in the starting zone, avalanche deflection, or protection in the runout zone are considered acceptable mitigation techniques, but artificial release of avalanches with explosives or artillery is not. Similarly, the model regulation lists earthquake-resistant design according to the ICBO Uniform Building Code as an acceptable mitigation technique in designated seismic areas. Mitigation measures are not required to issue a permit for certain 'allowable uses' in geologic-hazard areas, such as agricultural uses, certain industrialcommercial uses (loading and parking areas), and public and private recreational uses such as parks, golf courses, and nature preserves.

Results from detailed technical studies of the hazard and documentation of proposed mitigation techniques are required by the model regulation as a basis for review of the permit application. These studies must be performed by a qualified professional geologist or registered professional engineer. Although geologists are not registered in Colorado, a separate bill, H.B. 1574 (1973), sets the minimum qualifications for geologists who prepare reports or maps required by law (see p. 42). According to the model regulations, the local government must solicit and consider recommendations from CGS on the permit application; however, compliance with the recommendations is not mandatory.

Table 4 summarizes functions of local and state agencies in implementing H.B. 1041 with regard to geologic-hazard areas. House bills 1034 and 1041 constitute the Colorado equivalent of the General Plan Law in California. Designation of geologic-hazard areas and development of guidelines for their administration are analogous to the 'seismic safety' and 'safety' elements in the General Plan, respectively. The major difference is that local master plans (as they are called in Colorado) are not required in California, nor are designations of geologic-hazard areas. As of September 1981, 26 of 63 counties had adopted a master plan (Colorado Land Use Commission, 1981). Information on how many of these counties had designated geologic-hazard areas was not available.

Colorado planning law has some of the same weak. nesses as the General Plan and Special Studies \%ones laws in California. House bill 1041 does not provide state government with a direct means to enforce the requirement that local governments administer matters of state interest in accordance with state and local guidelines, such as standardized review procedures $(P$. Schmuck, oral commun.. 1982). Although the Colorado Geological Survey reviews designations of geologichazard areas and geologic reports prepared for permit applications, its recommendations are not compulsory and approval is not required. Other than the 'courtesy review' of designations and guidelines that local governments are required to solicit from the state, there is no other review requirement such as the California requirement in the Special Studies Zones Act that the local permitting authority must obtain an independent review of geologic reports by a registered geologist. The CGS often identifies and resolves potential problems in their reviews, but only to the extent that a local government or developer is willing to accept the recommendations (W.P. Rogers, oral commun., 1982).

Colorado H.B. 1041 and other similar bills that introduce special permit requirements can be an un. necessary burden to developers and builders because of additional applications, required supporting materials. and delays. Often different permits duplicate require. ments for supporting materials. The Colorado Land Use Commission has issued a permit-application form that local governments are required to use for development in areas of state interest (Colorado Land Use Commission. 1976). Even though a local government may have taken measures to incorporate the requirements of H.B. 1041 into its existing master plan and zoning procedures, at least two permit applications must be filed: one for the local zoning permit and one for the designated area under H.B. 1041. This problem could be eliminated by allowing local governments to incorporate the requirements of state laws into their own permitting procedures (P. Schmuck, oral commun., 1982).

One difficulty of administering geologic-hazard areas at the local level is reconciling hazard-area designations with other zoning ordinances. Hazards represent only one of many zoning considerations. Jefferson County, one of the most populated counties in Colorado, solved the problem by creating a separate Geologic Hazard Overlay District (G-H) zoning designation 
Table 4. Functions of local and state agencies regarding geologic hazard areas under Colorado House bill 1041 (1974).

\section{LOCAL GOVERNMENT}

1. Designates geologic-hazard areas, among other 'matters of state interest,' in accordance with guidelines from the Colorado Geological Survey and Land Use Commission.

2. Holds hearings and solicits state recommendations on permit applications for development in geologic-hazard areas.

3. Grants or denies permits for development in geologic-hazard areas in accordance with established guidelines.

4. Receives recommendations and technical assistance from the Colorado Geological Survey and Land Use Commission to designate and administer geologic-hazard areas.

5. Sends recommendations on geologic-hazard areas to other local governments and the Land Use Commission.

6. On request of the Land $\mathrm{U}_{\text {se }}$ Commission, acts on designations of specific geologic-hazard areas.

\section{COLORADO DEPARTMENT OF LOCAL AFFAIRS}

1. Conducts statewide program to identify geologic-hazard areas and other matters of state interest (before June 30 , 1976).

2. Oversees and coordinates state technical assistance to local governments.

3. Provides financial assistance as authorized by law.

\section{COLORADO LAND USE COMMISSION}

1. Issues formal requests for local governments to take action in specific geologic-hazard areas.

2. Provides assistance, guidelines, model land-use regulations, and forms to be used for local designations of geologichazard areas, permit applications, and permits.

3. Reviews or delegates review of designations of geologic hazard areas proposed by local governments.

4. Submits recommendations to local governments for modifying proposed designations of geologic-hazard areas.

5. Issues written notices to county boards of commissioners on any activity believed to constitute a serious hazard to the public safety, followed by written cease-and-desist orders on behalf of the Governor if the county fails to take action.

\section{COLORADO GEOLOGICAL SURVEY}

1. Develops guidelines and model local regulations to designate and administer geologic-hazard areas.

2. Sends recommendations to local governments and the Land Use Commission to designate geologic-hazard areas based on current information.

3. Provides technical assistance to local governments concerning designation of geologic-hazard areas.

(J. McCalpin, oral commun., 1982). As its title implies, the $\mathrm{G}-\mathrm{H}$ district is superimposed on other zone districts and its regulations supplement those of the underlying district. The G-H zoning resolution states that "when the regulations of this district conflict with any provision of the underlying zone district, the provisions of the Geologic Hazard Overlay District shall control; otherwise, the provisions of any underlying district shall remain in full force and effect." A G-H district may be designated for any of six different types of hazards. Guidelines for district administration basically follow the model geologic-hazard-area regulation issued by the state Land Use Commission that specifies the types of geologic and hazard-mitigation information required with permit applications. The guidelines also reference CGS criteria (Rogers and others, 1974) as the primary source for geologic-hazard identification and mitigation procedures.

Colorado land-use laws, particularly H.B. 1041, have been effective in encouraging consideration of geologic hazards in local planning and incorporation of positive hazard-reducing land-use requirements in zoning ordinances. Virtually all heavily populated counties have designated and are administering geologic-hazard areas. One exception, surprisingly, is the City and County of Denver, which has elected not to participate in the 
program. Many smaller communities are actively participating. The town of $\mathrm{Vail}$ has incorporated avalanchehazard areas into its zoning ordinances, which has had a substantial impact on development. The initial hazardassessment studies used as a basis for the zoning in Vail helped improve public awareness of the issue and produced positive responses from many developers. Builders who avoid hazardous areas, or use such areas for recreation, or use avalanche-resistant designs, have generally received support from the public; but those who are indifferent to avalanche hazards often elicit critical and antagonistic public response that can jeopardize their ability to obtain financing (Ives and Krebs, 1978).

Effectiveness of the hazard-area-designation program (H.B. 1041) in preventing damage or injury from natural hazards is difficult to assess because of the lack of centralized records on individual cases. Open-space and low-density uses have been effective in reducing damage from floods and avalanches in many areas of Colorado. Colorado lacks other major catastrophic geologic hazards that affect large areas, such as frequent large earthquakes, which would provide more visible evidence on the effectiveness of hazard-mitigation measures.

\section{SUBDIVISION LAW}

One of the strongest responses by the Colorado legislature to public pressure that resulted from uncontrolled development in the late 1960)s was passage of a stringent subdivision law (S.B. 35, 1972). Because many problems of rapid growth in mountainous areas are related to geologic hazards, S.B. 35 requires that geologic conditions of an area be evaluated before a subdivision is approved by a county. The law applies to all division of land into single parcels of less than 35 acres within a county jurisdiction. Apparently the reason for having a maximum applicable parcel size of 35 acres was that larger parcels allow enough flexibility in land use that owners can avoid geologic hazards (W.R. Junge, oral commun., 1982). A county may elect to apply the same requirements to subdivisions that contain parcels of 35 acres or larger. Also, two or more counties may form a regional planning commission to implement the requirements of S.B. 35 .

Major provisions of the Colorado subdivision law that relate to geologic hazards are listed below.

1. Fvery county must require that subdividers submit data, surveys, analyses, and studies of relevant site characteristics, including topography, lakes, streams, geology, potential radiation hazards, and soil suitability.

2. The Board of County Commissioners must distribute copies of preliminary subdivision plans and accompanying information on site characteristics to appropriate state agencies, including the Colorado Geological Survey, for evaluation of geologic factors that have a significant impact on the proposed use. State comments and recommendations are normally due in 24 days.

3. No subdivision may be approved until the required studies and plans have been submitted, reviewed, and found to meet "sound planning and engineering requirements.'

4. No county may approve a preliminary or final plat unless hazardous conditions that require special precautions have been identified and proposed uses are compatible with these conditions.

The Colorado Geological Survey reviews all submitted information for geologic hazards and has had a major impact on subdivision plans and approvals. One weakness noted by CGS personnel is that they often do not know whether their recommendations have been implemented. Enforcement of S.B. 35 requirements is entirely at the county level, and some of the same problems exist as noted earlier for local implementation of the Riley and Subdivision Map Acts in California, including variability in the quality of documents ap. proved for subdivisions and the degree to which subdividers are required to modify their plans to make them more compatible with known geologic conditions. However, the requirement in Colorado S.B. 35 that subdivision plans and supporting information be submitted to state agencies for review allows for much more state input to the subdivision process than in California, thereby upgrading the overall quality of the review process and providing some standardization.

The most serious weakness of the Colorado subdivision law is that it applies only to counties. Incorporated municipalities are not required to adopt subdivision regulations or follow the procedures set forth in S.B. 35. The City and County of Denver, for example, is immune from the subdivision law. The decision to exempt municipalities from the law apparently resulted from inadequate legislative support for state involvement in municipal-level regulatory processes to the degree called for in S.B. 35. Although the law has been successful in regulating development in mountain areas where there are many serious problems associated with steep slopes, it exempts a major percentage of subdivisions in the state that could be subject to equally serious problems (for example, mine-related subsidence, flooding, and ground-water depletion in the urban environment). Some proposed subdivision areas have been annexed into an adjacent municipality to avoid the requirements of S.B. 35 (W.R. Junge, oral commun., 1982).

A disclosure law was enacted recently (S.B. 13, 1983) that applies to all residential development. The developer must analyze the hazard potential and disclose any potential problems to prospective homebuyers. 
Because there is no requirement for state review or for submitting copies of disclosure statements to the state, there apparently is little means of review or enforcement other than the threat of litigation for not disclosing known hazards. It is too early to determine the effectiveness of this new law.

\section{STATE-LEVEL PROJECT REVIEWS}

Major construction projects in Colorado that include many critical facilities are reviewed by the Colorado (ieological Survey and other agencies to determine the adequacy of siting, design, construction, and, in some cases, operation to reduce potential dangers to the public from geologic hazards. With the exception of dams and certain state capital-construction projects, state-level review is not mandatory. However, basic information (for example, project type, location, size, or cost) for all proposed projects that receive state or federal financial assistance through grants or loans is routinely provided to the CGS through the Colorado Clearinghouse. The Clearinghouse was established to implement the provisions of the federal office of Management and Budget (OMB) Circular A-95, which provided all states with the opportunity to review and comment on federally supported projects. ${ }^{3}$ The CGS may request a geologic report for any project that it believes is potentially dangerous to the public because of geologic hazards. Most applicants comply with the request and respond favorably to survey recommendations. If a significant problem is revealed and is not resolved by the builder, state or federal funds may be suspended. During 1981, CGS performed about 700 reviews through the Colorado Clearinghouse (W.R. Junge, oral commun., 1982).

The CGS reviews proposed capital-construction projects of other state agencies through memoranda of understanding or policy letters. Most state construction projects are supervised by the Colorado Division of Capital Construction, which is required to submit reports on soils and geology for review by CGS under a formal memorandum of understanding. Other agencies that do not have formal agreements with CGS may request review of construction projects and are strongly encouraged to do so by the Governor. Compliance with CGS recommendations is not mandatory, but most agencies respond favorably to the reviews (W.R. Junge, oral commun., 1982).

A program for review and inspection of dam construction and operation in Colorado exists under the State Engineer's Office and is similar to the dam-safety program in California. For proposed dams over $10 \mathrm{ft}$ high or with a greater than specified capacity, plans

${ }^{3}$ OMB Circular $\wedge-95$ was rescinded and replaced by Presidential Executive order 12372 in .July 1982 . NIthough Fxecutive order 12372 changed some procedural elements, the state revicw process remains intact. and specifications supported by a geotechnical report must be submitted for review. The State Engineer's Office employs geotechnical engineers to review these reports and may contract with private consulting firms for all or part of a review. During construction, an independent third party may be required to inspect the dam and report to the State Engincer's Office to ensure that construction complies with approved plans and specifications. The State Engineer's Office is required to inspect every operational dam under its jurisdiction annually. Because of staff and funding limitations, this requirement has been impossible to meet. Colorado has over 2,200 dams; of these, the State Engineers Office can only inspect about 400 each year. Consequently. most dams are inspected once every 4 to $5 \mathrm{yr}$, uniess a potential problem is brought to the attention of the State Engineer's Office. This weakness in the inspection program may be partially responsible for recent dam failures in Colorado. Many dams built before review procedures and construction standards were established are nearing the end of their safe, useful life. In July 1982, an earthfill dam at the headwaters of the Big Thompson River failed and caused several deaths and substantial damage to the Estes Park area. State inspection of the dam was overdue and was scheduled for later in 1982 .

Other major projects and critical facilities in Colorado are not subject to rigorous formal review and strict approval procedures as are some facilities in California. However, through the Clearinghouse, CGS can review and comment on many projects. A major weakness of this procedure is that only state- and federal-funded projects are recorded by the Clearinghouse. Unless controlled by local laws or unless a local government requests a review by CGS, privately funded power facilities and buildings for public occupancy, for example, may not be reviewed for geologic hazards (W.R. Junge, oral commun., 1982).

\section{MINIMUM QUALIFICATIONS FOR PROFESSIONAL GEOLOGISTS}

Under H.B. 1574 (1973), any geologic report that is required by law for a state or local agency or commission in Colorado must be prepared by a 'professional geologist.' 'There is no formal registration procedure for geologists in the state, but the law defines a professional geologist as "a person who is a graduate of any institution of higher education which is accredited by a regional or national accrediting agency, with a minimum of 30 semester (45 quarter) hours of undergraduate or graduate work in a field of geology and whose postbaccalaureate training has been in the field of geology with a specific record of an additional $5 \mathrm{yr}$ of geologic experience to include no more than $2 \mathrm{yr}$ of graduate work." Beyond these basic qualifications, selection of an appropriate professional to prepare geologic reports 
is left to the discretion of the person or agency who contracts the work and to the personal judgment of professionals who accept the work. Guidelines issued by the Colorado Geological Survey (Junge and Shelton, 1978) recommend that professional geologists who prepare reports for review by a state or local agency have education and experience in civil engineering, groundwater geology, Quaternary geology, geomorphology, and interpretation of aerial photographs.

Lack of formal registration for professional geologists in Colorado avoids the so-called club atmosphere to which many people in California object, but raises some question about consistency in judgment and evaluation when persons are selected to perform geologic work. Financial incentives may affect a geologist's judgment in accepting work for which he or she may be only marginally qualified. However, H.B. 1574 also eliminates the tendency to select a person for geologic work solely based on registration. and forces the contracting party and the consultant to evaluate professional qualifications based on the specific project. Because the requirement for educational and professional experience is more general, and a shorter experience period is required than in California (5 $\mathrm{yr}$ instead of $7 \mathrm{yr}$ ), built-in biases against some types of professionals (educators, for example) are reduced.

\section{SATUTORY AUTHORITY FOR THE COLORADO GEOLOGICAL SURVEY}

In the mid-1960s, Colorado was one of only three states that did not have a state geological survey, and the incidence of serious geologic problems assocjated with development of its mountain regions was rapidly increasing. Recognizing the need for state action on geologic issues, many professional geologists worked through the American Institute of Professional Geologists and the Association of Engineering (ieologists to develop a meaningful charter for the Colorado Geological Survey (CGS). Legislation was enacted to put the charter into effect and establish the Survey as a division in the Department of Natural Resources in February 1969 .

Similar to the California Division of Mines and Geology, the legislation establishing CGS (Colorado Rev. Stat. 34-1-101 and those that follow) outlines its general statutory authority and responsibilities. Other statutes, such as H.B. 1041 (land-use-planning law) and S.B. 35 (subdivision law), prescribe specific functions consistent with the charter. The provisions of Colorado Revised Statutes 34-1-103 stipulate that "the Colorado Geological Survey shall function to provide assistance to and cooperate with the general public, industries, and agencies of state government, including institutions of higher education, in pursuit of the following objectives, the priorities of which shall be determined by mutual consent of the state geologist (chief of the division) and the exccutive director of the Department of Natural Resources." Some stated objectives relate to geologic hazards: "(a) to assist, consult with, and advise existing state and local governmental agencies on geologic problems.... (c) to conduct studies to develop geological information..., (g) to evaluate the physical features of Colorado with reference to present and potential human and animal use... and (i) to determine areas of natural geologic hazards that could affect the safety of or economic loss to the citizens of Colorado." The statute requires the State Geologist to fulfill these objectives and to "work for the maximum beneficial and most efficient use of the geologic processes for the protection of and economic benefit to the citizens of Colorado."

With this charge, and because Colorado lacked any requirements to consider geologic information in landuse planning and development, a major task of CGS has been public education. Many people in Colorado objected to the use of geologic information as an infringement on their personal and property rights. Landowners and developers feared that geologic-hazard information would decrease property values and that the cost of geologic studies would outweigh the benefits. Public talks, testimony to legislative committees, newspaper articles, publications, conferences, and workshops were used to show how geologic information can save money, shorten development time, promote more efficient development, and provide a better product for the consumer (J.W. Rold, 1978). The CGS became involved in several important and controversial issues, such as proposed development in an area of known mudflows and avalanche hazards near Marble and a hazard assessment in mountain canyons after the Big Thompson River flood in 1976. These issues heightened public awareness of geologic problems, demonstrated the importance of using geologic information in development decisions, strengthened the credibility of CGS, and were major factors in the enactment of S.B. 35 and H.B. 1041 (W.P. Rogers, oral commun., 1982).

$\Lambda$ s in California, the annual legislative appropriation for the CGS is not itemized by project except for occasional short-term special projects. The State Geologist and the Executive Director of the Department of Natural Resources mutually determine the task priorities of the survey, and the State Geologist manages the budget accordingly. A basic philosophy of CGS is to place a relatively low priority on research and general geologic mapping and a high priority on problemoriented tasks that benefit the public directly. Thus, the emphasis is to technically assist local governments, inform the 'prudent layman,' and address specific issues and problems of public concern (W.R. Junge, oral commun., 1982).

In 1983, the General Assembly reduced funding for CGS to the salary of one full-time professional. Without funding from other sources, CGS would no longer be 
able to perform most of its statutory functions. However, new legislation allows CGS to perform work on a reimbursible basis; this mechanism has allowed CGS to continue many of its functions. Although CGS no longer performs some routine reviews in conjunction with Colorado planning and subdivision laws, it continues to review projects for other state agencies on request and addresses specific problems in local areas. The work is paid for by federal or state agencies, local governments or, in some cases, private companies. The work performed by CGS is restricted by its statutory authority, which remains unchanged, and the survey may not perform consulting work that competes with the private sector (W.R. Junge, oral commun., 1982).

\section{O'THER STATES}

Most approaches to hazard mitigation in other states are similar to measures adopted by California and Colorado. Variations exist primarily in emphasis, comprehensiveness, and the degree to which authority and responsibility are delegated to local governments. Many successful state programs use hazard-specific measures and emphasize problems that most concern the state. Massachusetts. for example, requires state review of proposed projects in coastal areas that could alter land that is subject to tidal action, coastal erosion, and flooding. Minnesota has adopted a statewide building code that emphasizes flood-proofing requirements (Baker and McPhee, 1975).

State-level approaches to reduce loss potential from geologic hazards fall into two categories: 1) legislation and regulations that impose strict state controls on land use and building methods; and 2) planning legislation that transfers authority and responsibility for zoning and regulation of most construction to local governments. In both cases, programs generally rely heavily on a state geological survey or a similar agency that evaluates hazards on a regional basis, provides public information and technical assistance, and technically reviews planning documents and proposed facilities. Planning legislation has been emphasized over strict controls in recent years, particularly with increasing public desire for local autonomy. Strict state-level controls are reserved for very severe or regional problems that are beyond the capabilities of a local government if a disaster occurs and for critical facilities that affect large numbers of people or the continued operation of which is essential. Dams and hospitals are examples of facilities for which construction is strictly regulated at the state level in many states.

Hawaii and Maine are among the few states that have adopted statewide zoning regulations that specify the types of activities and construction permitted within each zone and incorporate hazards considerations into the zoning process. In Maine, one type of state zone is a 'protection zone' that regulates development on flood plains and steep slopes. Planning legislation has been enacted in lieu of strict statewide controls in Oregon and Wisconsin. Seven separate laws in Oregon's 'land-use package' establish requirements for local land-use planning, which must incorporate hazards considerations. The Wisconsin law encourages local flood-plain zoning but allows the state to impose its own zoning laws if the local government fails to do so. In Mississippi. a statewide building code has been enacted that local governments may modify to suit local conditions and preferences (Baker and McPhee, 1975).

Many states have established temporary or per. manent commissions to advise the Governor, state agencies, the legislature, and local governments on land-use matters or hazards-related issues. In 1977, a temporary Seismic Advisory Council was established in Utah to recommend a program of seismic-hazard evaluation and mitigation to the Governor and legislature. The council disbanded when its mission was completed in 1980 (Carter, 1983).

Most states have a geological survey that collects geologic data and provides public information and technical assistance on hazards to local governments, developers, and individuats. Local governments use this information and sometimes perform their own studies to support hazards-related land-use plans and zoning ordinances that they develop on their own initiative. The Utah Geological and Mineral Survey has a Hazards Section that identifies and maps geologic hazards throughout the state as required by state code. Similarly, the Illinois Geological Survey identifies hazards and brings them to the attention of local property owners, eity governments, or regional planning bodies and advises other agencies on hazards issues that affect their various functions.

\section{FEDERAL HAZARD-MITIGATION PROGRAMS IN ALASKA}

Many hazard-mitigation and disaster-preparedness programs that affect $\Lambda$ laska exist at the federal level. Federal programs emphasize disaster relief, regional studies, basic research on causal factors and processes, development of prediction capabilities and warning systems, and improvement of design standards and construction technology. Some major programs that benefit, or could benefit. Alaska are discussed in this section.

\section{DISASTER RELIEF}

The federal Disaster Relief Act of 1974 (Public Law 93-288) provides financial assistance to state and local governments when the President declares an area a disaster or emergency. Under the program, the Federal Emergency Management Agency (FEMA) administers grants from the President's Disaster Relief Fund. Other agencies, such as the Small Business Administration and Farmer's Home Administration, provide disaster-relief loans.

Alaska has been a major recipient of financial assistance from the President's Disaster Relief Fund. From 1961 through 1979 (the President's fund existed 
before the Disaster Relief Act was passed in 1974), Alaska received about $\$ 76$ million from the federal government to assist in recovery from major disasters. The 1964 earthquake and 1967 Fairbanks flood accounted for 83 percent of Alaska's total FEMA receipts as of 1979. From 1961 to 1970, Alaska's per-capita share $(\$ 221.81)$ was the largest of any state (Office of Emergency Preparedness, 1972). However, contributions from the President's Disaster Relief Fund generally cover only a small portion of the total damages. Assistance from the Disaster Relief Fund for recovery from the 1964 earthquake, for example. only amounted to about 16 percent of the total estimated damages. Although the U.S. Army Corps of Engineers performed much of the reconstruction at federal expense, a major share of the burden for disaster response and recovery was and remains at the state and local levels.

Although some improvements have been made in recent years, a major deficiency with disaster-relief and insurance programs in general is that eligibility for benefits is often not contingent on implementation of risk-reduction measures, For this reason, many programs have discouraged hazard mitigation by failing to offer the proper incentives and rewarding lack of foresight. Unconditional availability of disaster assistance probably grew out of the notion that disasters are 'acts of God' and cannot be prevented or mitigated; therefore, every. one should be equally eligible for assistance.

The Disaster Relief Act of 1974 established some conditions of eligibility for federal disaster loans and grants to encourage hazard mitigation at the state and local levels. As prerequisites for financial assistance, the law requires that postdisaster reconstruction or repair financed with federal relief funds must conform with applicable codes and standards, and that hazards from similar future events in the affected area must be evaluated and appropriate mitigation measures must be adopted. These requirements apply only to postdisaster actions and still do not affect eligibility based on pre. disaster mitigation.

Some of the most significant advances in promoting hazard mitigation in conjunction with federal disaster relief have been in the area of flood hazards. The National Flood Insurance Program not only offers a means to distribute financial losses, but also provides positive incentives for flood-hazard reduction. Communities must meet certain requirements to participate in the program, and state governments assist by coordinating programs within their borders. To qualify for federally subsidized insurance, the community must adopt preseribed land-use controls and construction standards for areas potentially affected by the $100-\mathrm{yr}$ flood. For example, the lowest floor of a structure must not be below the level of the $100-\mathrm{yr}$ flood or storm-surge height unless adequate flood proofing is provided.

A Flood Disaster Act was passed in 1973 to improve incentives for community participation in the National Flood Insurance Program. This act increased available insurance coverages and prohibited federal financing of projects in flood areas unless the community participated in the program. The latter prohibition includes projects financed by federally insured banks and savingsand-loan associations. Community participation has increased dramatically sine the Flood Disaster Aet was passed. In Alaska, state-backed mortgage-loan financers also require flood insurance in the $100 \cdot \mathrm{yr}$-flood area as a prerequisite for loan approval.

\section{REGIONAL STUDIES}

Several federal agencies perform research and map areas that provide useful information for describing geologic hazards on a regional scale. Most notable are programs of the U.S. Geological Survey (USGS) that produce topographic and geologic maps and evaluate regional seismic activity. These programs assess regional problems and identify areas that require more detailed study. They are not generally adequate for site-specific decisions or local land-use planning because map scales are small and subject treatment is general. Although regional geologic quadrangle maps $(1: 250,000$ seale $)$ are available for most of the continental United States, large areas of $\Lambda$ laska have not been mapped at this seale. In addition, geologic hazards are not generally identified on geologic quadrangle maps. The maps provide approximate ages and brief descriptions of bedrock units and surficial deposits, but must be interpreted to infer potential geologic hazards. Map information must be supplemented by additional studies and more detailed data to produee hazards maps that are useful for plan. ning.

The USG has primary responsibility for regional earthquake-hayard studes under the Earthquake Hazards Reduction Program (EHRP) established by Public Law 95-124 in 1977. This is the largest long-term federal program devoted to earthquake-hazards mitigation in the United States. The National Oceanic and Atmospheric Administration (NOA $)$ manages the Alaska Tsunami Warning Center in Palmer where 15 seismographs are monitored in Alaska and around the northern Pacific Ocean. Other short-term projects are funded by various federal agencies to evaluate the seismicity and seismic: hazards of specific areas in relation to activities for which they have management responsibility. In recent years, the Department of Energy has funded regional seismograph networks (o) determine geothermal-energy potential and earthquake hazards on the Alaska Penin. sula. The Bureau of Land Management (BLM), through NOAA. has provided major funding for seismograph networks to determine earthquake hazards to oil development on the Nlaska continental shelf. The BLM NOAA program provided about $\$ 1$ million annually to operate seismic networks in Alaska and analyze the data. However, this and most other hazards-related funds were phased out by the end of fiseal year 1982.4 The Department of Energy has reduced its funding for seismic studies in Alaska. As a result, many seismograph stations have been dismantled, and more will be removed if adcquate support is not maintained (Davies. 1983).

\footnotetext{
${ }^{4}$ The fiscal vear for the fecteral government is october 1 through September 30 .
} 
Although EHRP is a large national program with broad scope, it sets no goals or policy to establish long-term, minimum seismograph networks nationwide or map earthquake hazards at minimum scales in all areas of high seismic risk. The USCiS share of funding under the national program has been about $\$ 30$ million annually since 1978. Distribution of funds among the four major elements of the USGis program (fundamental studies, earthquake prediction, induced seismicity, and hazards assessment) has remained relatively constant. with about 50 percent going to fundamental studies and hazards assessment. Under these two programs, the USCiS operates limited seismograph networks and studies earthquake hazards in selected regions. Limited funding for these program elements on a national scale has forced the USGS to concentrate on heavily populated areas that have sufficiently high seismic activity to generate useful data in a reasonably short period, and that are relatively accessible so that the cost of obtaining data is not excessive (R.A. Page, oral commun., 1982). Alaska has received about 4 percent of the annual USGS budget for the earthquake-hazards-assessment portion of the national program, compared to 31 percent for California, 17 percent for the southeastern United States, 16 percent for the northeastern United States, and 13 percent for the central Mississippi valley (Hamilton, 1978). The only seismic instrumentation in Mlaska supported by the EHRP is a small network on $\Lambda$ dak Island that provides data to develop earthquake-prediction capabilities and a network operated by the USGS in southern and southeastern Alaska. The balance of Alaska funding goes to studies of earthquake-related ground instability in the Anchorage area, measurement of crustal deformation in two areas that are thought to have potential for major earthquakes in the near future, and interpretation of seismotectonic processes in southern Alaska from geologic and seismologic data (Hays. 1979; Reed, 1981).

From FY 1980 through FY 1984, USGS objectives and anticipated funding for its portion of the EHRP remained unchanged from previous years (Hays, 1979). Although it has been argued that FHRP has given only minor support to Nlaska because other agencies (mainly DOE and BLM-NOAA) have substantially funded seismograph networks in Alaska, there are apparently no plans to shift more support to Alaska to compensate for the loss of funding from other agencies.

\section{BASIC RESEARCH}

A major activity of the USGS is basic research into processes and factors that affect the distribution, frequency, and severity of geologic hazards. Although much of this work is performed by USGS personnel, some funding is provided to universities, state governments, and private consultants. The National Science Foundation (NSF) also supports basic research related to geologic hazards. Information from these studies is used by federal, state, and local agencies, engineering firms, architects, and planning consultants to improve hazardsmapping and prediction capabilities, assess risks. and develop better approaches to hazard mitigation.

$\Lambda$ bout 40 percent of the Earthquake Hazards Reduction Program is basic research. As part of its share of the program, The USGS evaluates the earthquake potential of seismically active areas, assesses earthquake hazards, develops earthquake-prediction capabilities, and provides data on earthquake occurrences and strong ground motion. The NSF supports research on fundamental earthquake causes and processes and engineering approaches to mitigate earthquake effects (Hamilton, 1978, Schnell and Herd, 1983).

The USGS will probably expand its research on landslides under a proposed National Landslide Hazardreduction Program. The program's major goals are to determine the geologic, topographic, and hydrologic conditions that contribute to slope failures; determine factors that lead to changes in stability; analyze past failures to develop prediction capabilities; and recommend methods to mitigate landslide damage (U.S. Geological Survey, 1981). How much of this program will be performed in Alaska is unknown, but the research results should apply to mapping landslide hazards and improving risk-reduction methods in the state.

Two other hazards-related programs in the USGS in Alaska are the Arctic Environmental Studies Program and the Volcanic Hazards Program. The principal goal of both programs is to develop a better understanding of geologic processes in Alaska so that their potential effects in developing areas can be determined. The Arctic Environmental Studies Program obtains base-line geotechnical data for land-use planning in transportation corridors and other developing areas. The program also studies problems that arise during operation of the Trans-Alaska Pipeline System to provide a basis for avoiding or minimizing similar problems to other proposed facilities. The Volcanic Hazards Program studies voleanic deposits to determine the history and style of volcanic eruptions. $\Lambda$ small part of this program monitors seismic and geochemical changes that may provide clues to future activity (Reed, 1981).

\section{PREDICTION AND WARNING}

The federal government supports numerous programs to advance technology for predicting major events. The weather-prediction program of the National Weather Service of NOAA is the oldest and most familiar. $\Lambda$ major objective of this program is to improve capabilities of predicting weather-related catastrophies, such as floods and hurricanes.

About half of the USGS share of the Earthquake Hazards Reduction Program (25 to 30 percent of the total national program) is devoted to development of prediction capabilities. The largest effort is in California, although the results will apply in many other parts of 
the country (Hamilton, 1978). Prediction techniques developed in California may have limited application in Alaska because of differences in the seismotectonic processes responsible for major earthquakes in the two states.

Techniques for predicting volcanic eruptions are improving, especially with the large quantity of data provided by the eruptions of Mount St. Helens. Much of this progress has been made under the USG iS Volcanic Hazards Program, which continues to study volcanoes in the United States and other parts of the world. This program includes studies of four volcanoes in the Cook Inlet region (Mt. Iliamna, Mt. Redoubt, Mt. Spurr, and Hayes Volcano), Mt. Edgecumbe in southeastern Alaska, and several volcanoes along the Alaska Peninsula and Aleutian Islands (T.P. Miller, oral commun., 1985). Internationally, there has been some success in pre. dicting voleanic eruptions, and warnings are being issued based on these predictions. The ability to predict an eruption currently depends on historic information about a volcano's eruptive style, internal structure, and seismic activity, and on the geophysical and geochemical signals that normally precede an eruption. The principle is the same for predicting other types of events: success depends on the delay between onset of the event at depth (as indicated by renewed seismic activity, for example) and the surface eruption. Volcano research by the USGS in the Cook Inlet area is not necessarily aimed at predicting eruptions of Cook Inlet volcanoes, but provides data to develop predictive models.

Prediction capability will be a principal objective of the proposed National Landslide Hazard-reduction Program, which will expand existing USC is landslide. research activities. Timing, geologic setting, mechanisms. rates, and extent of past slope failures will be studied to determine how these factors can be used to predict future failures.

The success of warning systems depends on timely and accurate predictions of events or recognition of conditions that indicate a high probability that a hazardous event will occur. Because predicting an event's onset and location is not yet possible for many hazards. warning systems often depend on prediction of the time and place of impact after an event begins. For example. flooding can often be predicted only after a cloudburst has begun, and warnings must be issued and acted on during the limited time available as the flood develops. Similarly, the federal government has developed warning systems for hurricanes and tornados that are based not on predictions of occurrence, but on estimates of the time and place of impact once the storm has started.

Tsunami-warning systems are highly successful and effective. at least for tsunamis that originate at a dis. tance, because many hours may pass after the tsunami is generated and before the waves reach a distant shoreline. In Alaska, the major difficulty in issuing tsunami warn. ings is inadequate communications with many small. remote communities in vulnerable coastal areas. The Alaska Tsunami Warning Center, operated by the National Weather Service in Palmer, issues warnings for the entire northern Pacific Ocean. The Alaska Division of Emergency Services assists by improving communications capabilities and supplementing public.education programs to instruct coastal residents on how to respond to warnings and how to recognize the signs of a local tsunami.

Snow-avalanche warning systems use weather forecasts and observations of snowpack conditions to determine the danger of avalanche activity rather than to predict or warn of individual events. The Alaska Avalanche and Fire Weather Forecast System (AAFWFS) was established by the federal government and the state of Alaska and began operation in 1980 . The U.S. Forest Servier (USFS) is lead agency for the program, and the Nlaska Department of Public Safety was designated to represent the state and coordinate program participation by other state agencies. Objectives of the AAFWFS are to aid fire-suppression agencies in their management of resources and fire-related activities; provide mountainweather and snow-stability forecasts to evaluate hazard levels; maintain an atlas of avalanche occurrences and paths; identify hazard zones to develop zoning regulations; and conduct a public-awareness program about. aralanche dangers and accident presention.

The fire-weather-service function of $\triangle A F W F S$ helps the National Weather Service prepare daily and spot fireweather forecasts from $A$ pril 15 to September 15 of each year. From september 15 to April 15, the A AFWFS provides mountain-weather and snow-stability forecasts that allow users to evaluate hazards and make scheduling decisions. Responsibilities for other avalanche-related activities are delegated by state legislation (Alaska Stat. 18.76.010) to the Department of Public: Safety, which in turn has delegated some of the tasks to other state agencies. Federal participation in the program consists of monetary contributions from the BLM and USFS and support through the services of federal personnel.

The USGS has developed a system for notifying state and local governments. other federal agencies, and the public of potential or imminent dangers from geologic hazards. A notice is formalized as a cieologic Hayard Warning when a situation poses a risk greater than normal and warrants considerations of a timely response to ensure public safety (U.S. Ceological Survey. 1984). A (ieologic Hazard Warning is accompanied by copies of scientific papers or reports that provide the basis of the notification, descriptions of the known geologic and hydrologic conditions, and an offer to provide appropriate technical assistance to affected state and local governments. Whenever possible, warnings are accompanied by estimates of the time, place. and magnitude of the expected event and descriptions of possible geologic or hydrologic events. 
The original Federal Register announcement of the hazard-notification system (U.s. (ieological Survey, 1977 ) points out that the system does not have a nation wide capability to issue notifications of hazardous conditions wherever and whenever they may exist. It also does not relieve state governments of the responsibility to keep apprised of potential hazards. States may request an evaluation of a potential hazard by the USGS for possible issuance of a notice, wateh, or warning. The notice also clearly divides the responsibility among federal, state, and local governments:

"The U.S. Geological Survey recognizes that providing earth-science information, in accordance with its expertise, is only the first of the inputs needed by state and local governments and the public in mitigating the effects of geologic hazards. The actual adoption of the most effective mitigation measures by local authorities will result from a cooperative effort by agencies at all governmental levels and by non-governmental organizations and the public. Decisions for adoption of such mitigation measures should be based upon a broad range of earth-science, engineering, and socio-eco. nomic information;" and "...recommendations or orders to take defensive actions are issued by officials of state and local governments, where the police and public safety authority rests in our governmental system."

\section{CONSTRUCTION TECHNOLOGY}

Most major advances in construction technology and design standards continue to come from private industry. In a few areas, such as seismic design. the federal government conducts programs to develop standards for its own facilities and promote improve. ments in state and local building codes. The U.S. Army Corps of Engineers, Bureau of Reclamation, and the National Bureau of Standards are responsible for most of this work within the federal government. In addition, $\mathrm{NSF}$ supports research in seismic engineering as part of EHRP. Most research addresses methods to determine design events, analyze the response of soil and structures, determine the potential for failure of slopes, embankments, and foundations, and develop technology for earthquake-resistant construction (Schnell and Herd, 1983).

\section{STATE AND LOCAL GEOLOGIC- HAZARD PROGRAMS IN ALASKA}

The most significant progress in dealing with geologic hazards in Alaska has been in disaster preparedness. Enactment of a comprehensive disaster act in 1978 established the Alaska Division of Emergency Services and began a program that has significantly improved disaster preparedness at state and local levels. Although the Alaska Disaster Act addresses hazard mitigation, progress in this area has been limited. Local planning for flood hazards is improving, primarily in response to federal eligibility requirements for flood insurance and through assistance provided by the Alaska Department of Community and Regional Affairs.

Limited progress has been made to develop land-use. planning and construction standards at state and local levels as a means of reducing losses from other geologic hazards in Alaska, particularly for hazards that are potentially catastrophic. However, state funding for engineering-geology and seismic-monitoring programs beginning in FY 1984 indicates some interest in such programs.

\section{DISASTER PREPAREDNESS, WARNING SYSTEMS, AND PROTECTION WORKS}

In 1977, the Alaska Legislature and Governor adopted the Alaska Disaster Act (Alaska Stat. 26.23), based on the Example State Disaster Act by the Council of State Governments (1972). This law expanded the former State Disaster Office into a new Division of Emergency Services (DES) in the Department of Military Affairs and gave it broad responsibilities in disaster preparedness. These responsibilities include (from Alaska Stat. 26.23.040) such actions as preparing a comprehensive state emergency plan, assisting local governments in designing their emergency plans, distributing emergency food and supplies, establishing public-information programs, and arranging for public and private facilities during emergencies. In preparing the state emergency plan, DES is responsible for recommending land-use and building regulations to reduce the impact of disasters.

The Alaska Disaster Act also provides for community disaster loans. grants to disaster victims, temporary housing, and removal of debris. The Governor is required to consider steps for disaster prevention, and appropriate state departments are required to identify areas vulnerable to disasters and study ways to reduce the dangers. However, disaster preparedness is emphasized, and functions that relate to hazard mitigation are primarily advisory.

A state emergency plan prepared by DES in accordance with the Alaska Disaster Act was adopted in 1978 and spells out disaster-response and planning functions of local. state, and federal government agencies that concern floods. forest fires, earthquakes, tsunamis, volcanic eruptions, and 'utilities emergencies.' Although most assigned responsibilities address disaster preparedness and response, some relate to predisaster mitigation. For example, one responsibility assigned to local governments that concerns earthquakes is "land-use planning and seismic building codes to minimize the adverse effects of earthquakes on the community." However, because the emergency plan is not incorporated in state regulations, it lacks the force of law to require local governments to carry out this responsibility. The plan goes into effect when the Governor 
declares a disaster, which is too late to implement predisaster mitigation. In effect, the emergency plan is an advisory document and, although valuable as an action plan during a state emergency, does not mandate predisaster hazard mitigation by other state agencies or local govermments.

Warning systems and related communications facilities are hazard-mitigation functions for which DES has major responsibility and has made substantial contributions in recent years. The DES coordinates with the federal Tsunami Warning Center in Palmer to issue timely warnings by providing and maintaining communications facilities throughout the state. The capability to communicate tsunami warnings to remote coastal areas is improving as the communications system is upgraded and expanded. In conjunction with its involvement in the Tsunami Warning System. DES conducts publiceducation programs in coastal villages to instruct residents on how to respond to warnings and how to recognize and respond to indications of local tsunamis for which warnings are not possible (I). Thomason, oral commun., 1982).

The ability of DES to fulfill its statutory responsibilities is limited by its funding. Funding for day-to-day operations has been barely sufficient to maintain a small staff at its headquarters office in Palmer and at a few field locations around the state. Only when a disaster is declared by the Governor does DES acquire and administer substantial funds for disaster-response operations. One responsibility that has suffered because of limited funding is assistance to local governments for preparing emergency plans (D). Thomason, oral commun., 1982).

The State of Alaska has major statutory responsibility for the Alaska Avalanche Warning System, which is part of the Alaska Avalanche and Fire Weather Fore. cast System (AAFWFS). Various state agencies participate in the avalanche-warning system or contribute information according to personnel and budgetary capabilities. Because of funding limitations, the proposed organization has never been fully staffed (Johnson, 1982). The program director and an avalanche specialist must contribute their time subject to the priorities of other duties. Two meteorologist positions are provided by the Nlaska Railroad (a prime user of the warning system), and weather and snowpack information along the Seward Highway is generally provided by the Seward Highway Avalanche Project (SHAP), which is operated by the Alaska Department of Transportation and Public Facilities. The University of Alaska Arctic Environmental Information and Data Center operates the Alaska Avalanche Forecast Center, which maintains a statewide data base of weather, snow-stability, and avalanche occurrence data, including a special data base for SHAP (Fredston and Sweet, 1985). The Alaska Division of Geological and Geophysical Surveys has prepared avalanche atlases more or less independently of the joint program. Funding limitations eliminated the position to provide information and avalanche forecasts for the Juneau area (Johnson, 1982).
For these reasons, the Alaska Avalanche Warning System is only partially meeting its statutory responsibilities. Users and participants cite inadequate funding, absence of structure or direction, inexperienced staff members, lack of guidance from knowledgable avalanche specialists, and poor integration with user needs as reasons for the program's poor performance (Johnson, 1982). The USFS recommended that the entire program be taken over by the State of Alaska under the management of a single state agency.

Alaska statutes have some provisions for protection works through state participation in flood-control projects (Alaska Stat. 35.07.010). Under this law, state government assumes 90 percent of the nonfederal costs of federally approved flood-control projects that include planning, land acquisition, construction, and maintenance. If the project is to protect facilities under state responsibility (for example, highways, roads, parks, or fish and game facilities), the state assumes all nonfederal costs.

In 1977. H.B. 425 was introduced in the Alaska Legislature to establish an erosion-control fund in the Department of Community and Regional Affairs. but was not passed. The fund would have been used to support grants to municipalities of up to $\$ 25,000$ to cover 80 percent of the total rost of an erosion.control project to protect public property. In the absence of an ongoing erosion-control fund as proposed in 1977, some communities have obtained state financial assistance for erosion control by special appropriation. Application for the funds is made to the Legislature in the same manner as for other capital-improvement projects.

\section{ALASKA PLANNING LAW AND LOCAL LAND-USE REGULATION}

The Alaska Constitution establishes two levels of local government, cities and boroughs, that are classified according to such factors as population, geography, economy, and transportation. Organized boroughs are designated as first, second, or third class, and cities are designated as first or second class. First-class boroughs and cities have the most powers of self government. An organized borough and all cities within it may unite to form a unified municipality with all powers of first-class cities and boroughs. Currently, there are 11 organized boroughs in Alaska that comprise 25 percent of the state's total area and contain 95 percent of its population. The remaining 75 percent of the state's area is designated the unorganized borough. Of the 11 organized boroughs, three are unified municipalities (Anchorage, Juneau, and Sitka), one is first class (Fairbanks North Star Borough), six are second class, and one is third class (Haines).

Requirements and powers for planning and zoning are delegated by the legislature (Alaska Stat. 29.33) to cities and boroughs based on their class. First- and second-class boroughs must provide planning and zoning on an an areawide basis, but may delegate planning and 
zoning powers to cities in their jurisdictions. Planning and zoning are optional for third-class boroughs. In the unorganized borough, first-class cities must, and secondclass cities may, provide planning and zoning. The Alaska Land Act (Alaska Stat. 38.05 ) requires the state Department of Natural Resources to provide planning and zoning in the unorganized borough outside cities that provide their own and in third-class boroughs if planning and zoning are not provided by the borough. The state owns and classifies some land within organized boroughs, but is required by state law (Alaska Stat. 35.30 .020 ) to comply with local planning and zoning ordinances to the same extent as other landowners.

To fulfill the planning and zoning requirement, firstand second-class boroughs must have a planning commission of at least five members. The commission must prepare a comprehensive plan for systematic develop. ment in the borough, zoning ordinances to implement the plan, and a subdivision ordinance (Alaska Stat. 29.33.080). State law provides very generalized guidelines for these plans:

"The comprehensive plan is a compilation of policy statements, goals, standards, and maps for guiding the physical, social, and economic development, both private and public, of the borough, and may include, but is not limited to, the following: statement of policies, goals, standards, a land use plan, a community facilities plan, a transportation plan, and recommendations for plan implementation" (Alaska Stat. 29.33.085).

The planning commission must review the plan at least once every $2 \mathrm{yr}$ and make recommendations to the borough assembly, which must "regulate and restrict the use of land and improvements by districts" in accordance with the plan.

The Alaska Division of Municipal and Regional Assistance (DMRA) in the Department of Community and Regional Affairs provides financial and technical assistance to local governments on request to partially offset budgetary and personnel limitations they face in preparing the required comprehensive plans. The DMRA coordinates the National Flood Insurance Program in Alaska and has been instrumental in having many communities comply with the program by helping them prepare flood-plain regulations. Other hazards are not systematically addressed by DMRA in its planningassistance program (C.L. Miller, oral commun., 1982).

State financial assistance for planning is available to first- and second-class boroughs and first-class cities in the unorganized borough through grants and revenue sharing. The DMRA provides special-purpose grants on a funds-available basis and administers annual revenue-sharing funds to help pay for general municipal services. Boroughs that provide land-use planning receive $\$ 2$ per capita annually from this fund.

Nlaska's present land-use laws and the federal Alaska National Interest Lands Conservation Act of
1980 were influenced by recommendations of a Joint Federal-State Land Use Planning Commission that was established by the legislature in 1972 and was replaced by the Alaska Land Use Council in 1980. Most recommendations were related to resource development, preservation of lands in state and federal management systems. and land exchanges and disposals to satisfy terms of the Statehood Act and Alaska Native Claims Settlement Act. Few specific recommendations regarding geologic hazards resulted from the Commission's work. However, one recommendation for state-land policy outlined "primary public interests in retaining state lands in public ownership," which included "to restrict development in hazardous areas" (Joint FederalState Land Use Planning Commission, 1979).

\section{GEOLOGIC HAZARDS IN LOCAL PLANNING AND ZONING}

Alaska law neither requires nor encourages consideration of geologic hazards or any other specific issue in local comprehensive plans or ordinances, except through the Alaska Coastal Management Program (p. 52). Because federal law requires adoption of land-use controls by communities in flood-hazard areas as a prerequisite to participate in the National Flood Insurance Program, most affected cities and boroughs in Alaska address flood hazards in their planning and zoning. Although local governments have authority to address other hazards, few do. Most local governments that have addressed geologic hazards have taken a broad approach and group hazards with other considerations, such as habitat preservation for creating generalized open-space districts. Some comprehensive plans identify specific local hazards and provide guidelines to develop or preserve affected areas.

The Municipality of Anchorage has adopted a comprehensive Flood-plain Regulation (ch, 21.60, Anchorage Municipal Code), as have 17 other cities and boroughs, to comply with the eligibility requirements of the National Flood Insurance Program. In addition, the municipality has adopted a Residential Alpine/Slope District in its Zoning District Regulation (sec. 21.40.115, Anchorage Municipal Code) to collectively consider a number of environmental factors, one of which is geologic hazards. Permitted uses are restricted to single-family dwellings, accessory structures, and certain conditional uses subject to approval by the planning department. Minimum lot sizes and dimensions are determined according to the slope of the lot. Although the statement of intent of the Residential Alpine/Slope district deciares that "creative site design and site engineering are essential" to ensure proper development, the district regulations do not establish design and engineering standards or procedures to implement this requirement. In early 1985 , the municipality initiated a natural-hazard risk assessment of the Anchorage area to provide a possible basis for strengthening hazard-mitigation policy in the zoning. district regulation. 
Zoning regulations in the Fairbanks North Star Borough (FNSB) (sec. 18.44.010. FNSB Code of Ordinances) include two zones that make minor references to hazards. The General $\Lambda$ griculture zone, intended primari. ly to preserve and develop agricultural uses, "may also be applied to lands containing soils which are not able to support intensive structural development..." In this application, the zone is generally used in areas of ice. rich permafrost or steep slopes. Uses are restricted primarily to one- and two-family residences, parks, schools, churches, facilities with few employees, livestock, and agriculture (not all-inclusive). An Outdoor Recreation zone was created to encourage open-space uses and specifically mentions providing floodways along the Chena River. Most development is prohibited in the Outdoor Recreation zone, unless directly related to recreation. The FNSB has also adopted comprehensive Flood Plain Building Regulations (ch. 15.04, FNSB Code of Ordinances) to comply with eligibility require. ments of the National Flood Insurance Program. In 1984, the FNSB began a comprehensive revision of its zoning ordinance. The new ordinance will contain a flood-plain 'overlay zone'; no other substantial changes concerning geologic hazards are planned.

Land-use controls that are recommended in a comprehensive plan are not effective unless zoning ordinances are adopted to implement them. Further, a zoning ordinance for mitigating hazards is not effective unless hazardous areas are identified, maintained with a conservative approach to variances and conditional uses, and enforced. Nlthough some local governments in Alaska have addressed geologic hazards in their com. prehensive plans and, to a lesser extent, in zoning ordinances, implementation has been limited. Some factors that hamper implementing local hazard ordjnances in Alaska are general public resistance to land-use controls; lack of technical background and concern about geologic hazards on borough planning commissions, assemblies, and staffs; lack of public information on potential hazards and associated risks: low awareness of potential legal liabilities of local governments with regard to injuries or property damage caused by natural hazards; and lack of sufficient enforcement personnel.

The Anchorage Coastal Management Plan and Comprehensive Development. Plan, both of which are referenced by title 21 (Land Use Regulation), describe extensive areas of known or suspected hazardous lands and recommend policies and controls for their proper management. Adoption of the proposed measures and their application to the identified hazardous areas have been limited, particularly in areas of high development. Technical reports and planning documents available before the 1964 earthquake identified many hazardous areas that were affected by major earthquake-induced ground failures in 1964; yet most hazardous areas are still zoned for residences or businesses. With the exception of Earthquake Park, all other areas along the shoreline in the Turnagain Heights area west of Fish Creek that failed during the 1964 earthquake and areas next to the headwall scarp are still zoned R-1 (singlefamily residential). In 1977 , a memorandum and proposed ordinance were submitted on request to the Municipal Assembly by the municipal Department of Law. The memorandum and ordinance recognized the potential hazards to public safety and welfare in the Turnagain Heights slide area and the potential liabilities to the municipality if another earthquake occurred. The proposed ordinance placed a $1 \cdot \mathrm{yr}$ moratorium on further development in the slide area to allow analysis of data and preparation of plans for future development; the ordinance was not approved by the Assembly (L.L. Selkregg, oral commun.. 1982).

In 1982. the Anchorage Assembly passed an ordinance that formally recognizes the Anchorage Geotechnical Advisory Commission as an advisory body to the municipality. This group of professional geotechnical engineers and geologists existed for several years as an ad hoc organization that provided informal recommendations and information to the municipality. Now the Commission is occasionally requested to provide formal input to the Assembly on matters related to zoning ordinances and building codes. Formal recognition of the Commission indicates the Assembly's increased awareness of the need to consider geologichazard issues.

In the Fairbanks North Star Borough, land-use controls receive strong public opposition, particularly in areas outside the City of Fairbanks. Another basic problem is the limited awareness among planning personnel and elected officials of potential geologic problems and associated legal liabilities (S.B. Hardy, oral commun.. 1983). To improve geologic-hazards mitigation in local planning requires improved public information on hazards in a form appropriate for land-use planning and the availability of technical expertise to the borough planning staff. An additional problem is the limited capability of the borough to enforce zoning laws. One borough employee is responsible for all zoning inspections outside the cities of Fairbanks and North Pole where development is scattered over an area roughly the size of New Jersey. With about 1,000 homes constructed in 1982, adequate z.oning enforcement has become nearly impossible.

\section{STATE LAND-USE PLANNING AND CLASSIFICATION}

The Alaska Division of Land and Water Management in the Department of Natural Resources is responsible for land-use planning and classification in the unorganized borough outside first-class cities. State-owned land within organized boroughs is also classified by the state. but is subject to additional restrictions under borough ordinances. State land may be conveyed to 
private parties, native corporations, cities, or boroughs after it has been classified. After state disposal, land-use restrictions generally conform to the original classification. but may be modified by the covenant of sale and may expire after a specified period.

State land-planning and classification regulations I'Title 11, Alaska Administrative Code, ch. 55, secs. 10 to 80 (11 AAC 55.010-55.280) ] do not address land-use management of hazardous areas. Several existing classifjcations could be applied because they restrict or prohibit high-density or residential uses, but only one land class (Greenbelt Land) specifically applies to hazardous areas (flood plains).

\section{ALASKA COASTAL MANAGEMENT PROGRAM}

A separate planning process that affects development in coastal areas was established by the Alaska Coastal Management Act of 1977 (Alaska Stat. 46.40). This law initiated statewide and district coastal planning to address development and conservation of coastal resources and coordinated planning in coastal areas. policies for resolving use conflicts, and public participation with local, state, and federal agencies in coastalzone management. Funding assistance is provided by the federal Coastal Zone Management program. When the state Coastal Zone Management plan was completed in 1979. Alaska became eligible to receive increased federal funding to administer the program and provide assistance to local governments in preparing district plans. Many local districts have completed their coastalmanagement plans and more are being prepared. The Department of Community and Regional Affairs oversees and assists in preparing district coastal plans; the office of Coastal Management administers the overall state program.

After state and district coastal-management pro. grams were adopted, the Alaska Coastal Management Act requires affected municipalities and state agencies to administer land and water uses in conformance with their plans. At the local level, zoning regulations must be adopted, and permits and variances that are consistent with the plan must be approved. At the state level, uses or activities under state jurisdiction that are consistent with state and local management plans and with other state laws and regulations that govern the activity must. be approved. Under the federal Coastal Zone Management Program, state and local governments may review federal activities for compliance with approved coastal plans.

State regulations developed under the Alaska Coastal Management Act establish minimum standards that must be met by state and district programs $(6 \mathrm{AAC}$ 80 ) and guidelines to prepare plans (6 AAC 85). Among issues that must be addressed are geophysical-hazard areas' in the coastal zone:
6 AAC 80.050. Geophysical Hazard Areas. (a) Districts and state agencies shall identify known geophysical hazard areas and areas of high development potential in which there is a substantial possibility that geophysical hazards may occur. (b) Development in areas identified under (a) of this section may not be approved by the appropriate state or local authority until siting. design, and construction measures for minimizing property damage and protecting against loss of life have been provided.

The state coastal-management plan does not delineate geophysical-hazard areas. This is recognized as an ongoing task of state agencies, primarily the Division of Geological and Geophysical Surveys, that requires continual data evaluation and mapping to identify geophysical hazards in 'areas of high development potential.' District coastal-management plans delineate geophysical-hazard areas and recommend measures for their management, but as the state plan recognizes, "it will be impossible for districts to thoroughly assess each hazard area and devise detailed standards for any conceivable use." The state plan obligates developers to conduct studies needed to determine appropriate siting. design, and construction standards. Districts and state agencies are expected to have enough general data to know when to require such studies from developers. In practice, however, data are often insufficient in an area. Although geophysical-hazard areas are continually being identified for the state and district programs, no requirements exist to periodically update coastalmanagement plans.

\section{SUBDIVISION LAW}

In Alaska, subdivision platting responsibilities and powers are delegated to cities and boroughs in the same manner as planning and zoning. The borough planning commission, or a separate borough platting board, has jurisdiction over the form and size of subdivisions, dimensions of lots, and arrangement of utilities, transportation, and other public facilities. The platting board must publish a subdivision ordinance with rules and regulations to implement this power. State statutes require that the platting board approve a plat before work can begin on a subdivision, unless a waiver is granted under special circumstances. The plat must show survey points, boundaries, calculations and angles used in the survey, and other information that may be required by ordinance (Alaska Stat. 29.33.160 to 29.33 .180 ). If the subdivision will have a central well, water samples must be submitted to the state Depart. ment of Environmental Conservation for analysis, but there are no state requirements to collect geologic or soils data for review. Except for state residential-land disposals and other areas under state jurisdiction, all 
reviews, permits, and additional platting standards are the responsibility of local government.

The Municipality of Anchorage and the Fairbanks North Star Borough have incorporated limited hazards considerations in their subdivision regulations. Anchorage subdivision regulations contain provisions for subdivision design that implement the requirements of the R-10 (Residential Alpine/slope) District in the zoning regulations: "Subdivision design in the R-10 District shall take into consideration known areas susceptible (o) landslide, mud and earth flow, talus development, soil creep, solifluction or rock glaciation. avalanche chutes. runouts or wind blast. Each lot or tract zoned R-10 shall include a building site which is not within such a known susceptible area" (sec, 21.80.120, Anchorage Municipal Code). Properly implemented, this regulation requires developers to provide suitable building sites on each lot. in a hazardous area. However, because the requirement applies only to the R-10 district, known hazards in subdivisions that are not zoned R-10 are not addressed, such as the Turnagain Heights slide area, which is zoned $\mathrm{R} \cdot 1$.

Title 17 subdivision regulations in the Fairbanks North Star Borough code take a more generalized approach to hazards: "In those arras where the planning commission has been presented with evidence to the effect that the preliminary layout, if approved and developed, would tend to result in a hazard to persons or property, or if evidence has been presented which tends to indicate that damage to properties lying beyond the boundaries of the proposed subdivision may occur. the planning commission may impose more restrictive standards than those already established in other sections of these regulations" (sec. 17.20.020). Property impairment caused by disturbance of unstable soils is cited as one type of damage to which this regulation applies. In practice, this section of the borough subdivision regulations is seldom, if ever, used to apply more restrictive development standards. A more com. mon practice is to change the zoning designation to one with a larger minimum lot size so that each lot eontains a variety of siting alternatives (S.B. Hardy, oral commun., 1983).

\section{SITING, DESIGN, AND CONSTRUCTION}

The State of Alaska and some borough governments make limited use of building codes and other standards for site selection, design, and construction of public and private facilities. Some standards require consideration of geologic factors and use of appropriate construction technologies to minimize the danger from any hazardous condition. Specific requirements of building standards and the way they are implemented depend largely on the type of facility and whether its construction is under local or state jurisdiction. Standards are less strict for small private structures than for large public facilities, and the review and permitting process is different if the code is enforeed by the state rather than the borough government. Review procedures for siting and design plans and for inspecting the project during construction are critical to sucessfully implement building codes and standards.

\section{STATE AND LOCAL BUILDING CODES}

The State of Alaska does not require local governments to adopt a building code, although it does give them the authority (Alaska Stat. 29.10.213). As part of the fire-prevention regulations in the state public-safety code, the state has adopted many sections of the ICBO Uniform Building Code (UBC) "to regulate all occupancies and buildings" (13 AAC 50.020). This regulation applies to all commercial, industrial, business, institutional, and public facilities in the state, and to residential buildings of four or more units. $A$ municipality may be exempted from code requirements if the municipal government has enacted satisfactory ordinances for review and approval of building plans and specifications. Sections of the UBC adopted by the state public-safety code include earthquake regulations (sec. 2312), but do not include sections that deal with soils, foundations, and slopes (UBC, chs. 29 and 70 ).

Building plans and specifications must be submitted to the state fire marshal for review, unless review responsibility has been transferred to the local government. The fire marshal's review concentrates on design aspects that affect fire safety. Consequently, plans and specifications are not reviewed for earthquake safety. Other than this chapter in the public-safety code, there is no statewide building code'.

Some boroughs and cities in Alaska have adopted the UBC by ordinane. usually with amendments, to regulate construction in their jurisdictions. In most cases, LBC sections that deal with potential geologic problems are adopted in their entireties with minor changes, including section 2312 (Earthquake Regulations), chapter 29 (Excavations, Foundations, and Retaining Walls), and associated appendixes.

In the Municipality of Anchorage, the UBC applies to all construction in the area formerly known as the City of Anchorage (Borough Service Area 30); the remainder of the borough is exempt from the UBC. Section 2312(1) of the UBC was reinstated in 1983 , with amendments; it requires installation of accelerographs in certain large buildings to record ground motion during strong earthquakes. The municipal building department reviews building designs and soils-investigation reports for compliance with minimum requirements of the $\mathrm{UBC}$. As long as the proposed design meets minimum requirements of the UBC, the building department has no local authority to decline a permit, even if it believes there is a potential hazard that is not adequately addressed by the UBC (R. Watts, oral commun., 1982). For example, although the $\mathrm{UBC}$ requires that a building be designed to 
resist stresses produced by lateral forces during an earthquake, it does not require that the building site be analyzed to determine the potential for earthquakeinduced ground failure. Consequently, a building could be designed to withstand earthquake shaking, but fail as a result of permanent differential movements of the ground on which it is built.

The City and Borough of Juneau has adopted the hazard-related sections of the UBC and, in some areas, has strengthened the requirements. For example, an additional factor that increases the design load according to building height must be included in the equation for determining design lateral-shear forces during earthquakes (sec. 19.06.010, City and Borough of Juneau Code of Regulations). For tall buildings, the resulting design load could be as much as 2.2 times that determined from the original equation in the UBC. Another change is an addition to chapter 29 of the UBC (Excavations, Foundations, and Retaining Walls) that partially compensates for the lack of adequate site-investigation requirements and gives the building official more power to ensure site safety. The addition requires that a qualified engineer submit an engineering report and recom. mendations for any proposed construction on soils that may have inadequate bearing capacity. The building official may incorporate the recommendations into the permit approval and any other requirements deemed necessary to ensure the stability and safety of the proposed structure.

Construction in the Fairbanks North Star Borough is not regulated by a building code. The City of Fairbanks, however, has adopted the UBC with no substantial amendments relating to potential geologic problems.

Local goverments differ in their approaches to adopting and implementing hazard-related building codes in Alaska. Their approaches reflect various backgrounds and attitudes of local elected officials and building departments rather than variations in severity of geologic problems in different areas of the state. For example, a UBC requirement to install earthquake accelerometers in large buildings in Anchorage was temporarily deleted when builders objected to the cost, but was later readopted (L.L. Selkregg, oral commun., 1983).

Adoption of a statewide building code or a state requirement for local adoption of codes is probably not the best solution to improve the role of building codes in reducing losses from geologic hazards in Alaska. The greatest need is to improve awareness by elected officials and the public of potential hazards and reasonable ways to reduce risks. The Anchorage Geotechnical Advisory Commission occasionally presents recommendations to the Municipal Assembly and meets with members of the planning department to discuss its recommendations and help resolve specific problems. If similar advisory services were available to local governments on a statewide basis, local implementation of hazard-related building codes would probably improve.
Another need is to improve the capability of local building departments to implement codes through adequate review of building plans and specifications for compliance with the geologic-and seismic-engineering requirements. In addition to sufficient funding to maintain adequate staffs, local governments would need to hire or contract reviewers and building inspectors who have had training or experience in earthquake and geologic engineering.

\section{CRITICAL FACILITIES}

The only critical facilities whose construction is regulated by the State of Nlaska with specific regard to geologic hazards are dams and health facilities. Until 1981. construction of school buildings was subject to state review and approval of engineering reports, plans, and specifications under the Health and Social Services code (7 AAC 22.100). However, this regulation was not enforced, at least during the last several years of its existence (R. Goldberg, oral commun., 1982). In January 1981, the Governor transferred many inspection and enforcement functions, including regulation of school facilities, to the Department of Environmental Conservation (Executive order 51). The new regulations developed by I)EC eliminated all state review and approval of engineering reports and construction plans for schools.

Construction of health facilities remains under the jurisdiction of the Department of Health and Social Services. Plans and specifications must be submitted for review, approval, and licensing by the department and must conform to codes and standards prescribed in the Health and Social Services code (7 AAC 09.050). In addition to the Uniform Building Code, the regulations require compliance with local building codes and special earthquake provisions and require submission of site surveys and soil investigations when notified by the department (7 AAC 09.060 and 7 AAC 09.090 - 09.110). The earthquake provisions require a seismic-investigation report to accompany the site survey and soil-investigation reports on new health-facility construction projects in UBC seismic zone III (which includes \%ones 111 and IV in later editions of the UBC). Plans and specifications for structural renovations of health facilities are also required to conform with the lateral-force provisions of the UBC. Nonstructural items such as book stacks and equipment must be properly secured to prevent or minimize undesired movement.

Plans and specifications for health facilities, along with supporting information, are reviewed by architects in the Division of State Health Planning and Development. Requirements and procedures are similar to those in California under the Hospital Seismic Safety Act. However, one requirement of California law that is not included in the Alaska regulations is that geologic and structural-design data be reviewed by professionals who are qualified in those fields. Although the difference may appear to be minor, the credibility of the review 
process is determined to a large degree by the technical expertise of the reviewers and has the greatest impact on the effectiveness of hazard-mitigation programs. In California, this is most apparent with regard to schools (Field Act) and health facilities (Hospital Seismic Safety Act; Woodward-Clyde Consultants, 1980a). Whether lack of this requirement in Alaska affects the adequacy of health-facility reviews for potential geologic hazards was not determined. Although the Division of State Health Planning and Development does not employ geologists or geotechnical engineers, this aspect of the review can be contracted to private firms (R. Goldberg, oral commun., 1982).

Dam construction is regulated under the Natural Resources code (11 AAC 93) that contains requirements to consider geologic and hydrologic factors in dam safety. Requirements for information that must be submitted to the Department of Natural Resources (DNR) for review depend on the size of the proposed dam. For dams that are higher than $20 \mathrm{ft}$ or have a storage capacity of 100 acre-ft or more (classified as large dams), an evaluation of earthquake effects (if it is in UBC zone III or IV), a seepage analysis, hydrologic data, geologic and foundation information, and procedures used to develop design criteria and construction specifications (11 AAC 93.170) are required. The same procedures and supporting information are recom. mended, but not required, for medium-size dams. Dams under $10 \mathrm{ft}$ high or that have a storage capacity less than 50 acre-ft (classified as smail dams) do not need DNR review or approval beyond granting the state waterappropriation permit.

Permit applications for dam construction are reviewed by engineers in the Division of Land and Water Management (DLWM) for compliance with applicable dam-safety and construction regulations. The DLWM does not employ engineering geologists or seismologists to review geologic or earthquake information but can contract private consulting firms (S.F. Mack, oral commun., 1982).

The present dam-safety and construction regulation is only $6 \mathrm{yr}$ old and has had little opportunity to be tested. No reviews for large dams have been conducted since the regulation went into effect in December 1979. Most large dams, which are generally hydroelectric, are regulated by the Federal Energy Regulatory Commission (FERC), which has its own requirements and review procedures for siting, design, construction, and operation.

The major difference between the dam-safety program in Alaska and its counterpart in California is that Alaska regulations do not specify minimum performance or design standards to mitigate geologic hazards to dams. The absence of these standards may contribute to uncertainty about what criteria will be used for granting or denying permits, especially when complex geologic, seismologic, and engineering problems are involved. Because of the complexity and uniqueness of each dam installation, design standards must remain flexible to accommodate and promote improvements in design technology. However. dams could be required to meet certain minimum performance standards without compromising design flexibility. An approach that has been successful in California is to require minimum performance under certain adverse circumstances. For example, California law allows no major release of water from a dam as a result of a maximum-credible earthquake or 1,000-yr flood (p. 31). Performance standards for other natural events could also be included.

\section{PUBLIC FACILITIES AND STATE-FUNDED CAPITAL-IMPROVEMENT PROJECTS}

Design and construction of most state facilities are the responsibility of the Department of 'Transportation and Public Facilities (DO'T/PF). Although DOT/PF usually obtains engineering-geology data during a project. there are no specified building codes or design standards set by state law to minimize potential effects from geologic hazards and no requirement to identify hazards before a project begins. State law does require state agencies to comply with local ordinances to the same extent as other landowners (Alaska Stat. 35.10.025 and 35.30 .020 ); thus many state facilities are subject to local building codes.

The only state capital projects that are routinely reviewed by the Division of Geological and Geophysical Surveys (DGGS) are those that receive federal funding and are thus circulated through the state Clearinghouse (see following section). In other states, interagency agreements often establish review procedures among several agencies for proposed state capital-construction projects. The state geological survey is generally one party to the agreement and is given responsibility to review potential geologic hazards. Such a procedure has not yet been established in Alaska between DGGS and other agencies like DOT/PF and the Alaska Power Authority that are responsible for capital-construction projects. The DGGS is occasionally asked to participate in reviews on a project-specific basis where major concerns develop regarding the geology of proposed construction sites, but does not budget specifically for this service.

Local construction projects financed with state capital funds are also not subject to state siting and design standards, except under the Alaska Coastal Management Program. When a local government receives state funds for capital-improvement projects, state regulations do not stipulate that geologic hazards be evaluated or that siting and design meet minimum requirements for hazards safety.

\section{PROJECT REVIEWS BY STATE AGENCIES}

State agencies may review and comment on many proposed actions by state and federal agencies and projects that are regulated, licensed, or funded under state and federal laws. A brief description and location map of 
the proposed project or action is distributed to appropriate agencies, and reviewers can usually request additional pertinent information. The DGGS reviews many of these proposals to identify potential geologic hazards and conflicts with known mineral or constructionmaterial resources.

Project reviews by DGGS fall into five categories: 1) Pederally funded or licensed projects for which descriptions are circulated by the state Clearinghouse under Presidential Executive order 12372 (see footnote on p. 42$) ; 2$ ) projects in the coastal zone that require a federal permit (usually from the Corps of Engineers) and must comply with the Alaska Coastal Management Program; 3) disposals and exchanges of state-land parcels under the Alaska Land Act;4) state selections of federal land under the Alaska Statehood Act; and 5) projects under the jurisdiction of other state agencies that request reviews by DNR on a largely informal basis. Of these five categories, only projects regulated by the Alaska Coastal Management Program must be reviewed against a state hazard-related development standard (see p. 52 ). Because hazard-related development standards do not exist for other projects, the use of geologic. hazards information is left to the discretion of the approving authority.

Two additional problems faced by DGGS in re. viewing for geologic hazards are the limited geologic information for many areas of the state and limited number of personnel. Reliable large-scale geologic maps exist for most areas of other states, but are available for only about 7 percent of Alaska (fig. 17).

\section{PROFESSIONAL REGISTRATION}

The few state and local laws in Alaska that require consideration of geologic hazards in siting and design generally require submission of geologic or soils-engineering reports, but are not specific about the professional qualifications of those who prepare them. Other state laws establish a state board of registration to set minimum qualifications and require engineers to register in Alaska. The state does not require professional registration of geologists, but provides optional certification for those who desire it. State certification is automatic if the applicant is certified as a professional geologist by the American Institute of Professional Geologists (Alaska Stat. 08.02.011). Certification re. quirements include a baccalaureate degree in geology or major subdivision, 5-yr experience (partial credit given for graduate degrees), and sustained record of high professional and ethical standards, as attested to by five professional geoscientists, at least three of whom are members of the Institute.

Geologic reports currently have a minor role in siting and design regulations, so lack of a registration requirement probably has little impact on building safety in Alaska. If hazard-mitigation programs are expanded at state and local levels to include requirements for geologic reports, registration or certification of geologists may become important because more unqualified persons will be tempted to take advantage of the increased demand for professional services. However, judging from the problems and controversy that have developed over the registration program for geologists in California (see p. 36), a similar elaborate registration program in Alaska may not be feasible. A stipulation that geologists who prepare reports required by state and local laws be certified according to the existing procedure (Alaska Stat. 08.02.011) and that they provide evidence of training or experience in the type of work required for the report should be adequate to protect the public from unqualified persons and yet be flexible enough to avoid undue restrictions. For instance, this procedure would allow many qualified out-of-state geologists who currently practice in Alaska to continue making their services available without having to pass a separate state qualifying examination.

\section{RESEARCH AND TECHNICAL SERVICES}

State-supported research on geologic hazards in Alaska takes place by two mechanisms. The DGGS is the primary state agency responsible for preparing maps and reports for the public on geologic resources and hazards and for providing technical assistance to local governments and other state agencies on geology-related matters. Most funding for DGGS comes from the annual state operating budget, although a limited amount also comes from federal agencies, such as the USGS. The second mechanism is through the University of Alaska. Until FY 1983, most of the university's funding for research, including geologic hazards, came from the federal government. In FY 1983, when the federal share of research receipts at the university dropped to 36 percent, the State of Alaska became the university's dominant funding source (University of Alaska, 1983). Another funding mechanism, discontinued by the Legislature in 1984, was the Alaska Council on Science and Technology (ACST). The ACST was one means by which researchers at the University of Alaska could obtain state funding and was also a funding source for some nonuniversity scientists and research organizations.

\section{DIVISION OF GEOLOGICAL AND GEOPHYSICAL SURVEYS}

The Alaska Division of Geological and Geophysical Surveys, as it now exists, was established by the Legislature in 1972 as a division of the Department of Natural Resources. State statutes require DGGS to "conduct geological and geophysical surveys to determine the potential of Alaskan lands for production of metals, minerals and fuels; the locations and supplies of ground waters and construction materials; the potential geologic hazards to buildings, roads, bridges and other installations and structures; and...other surveys and investigations as will advance knowledge of the geology of 


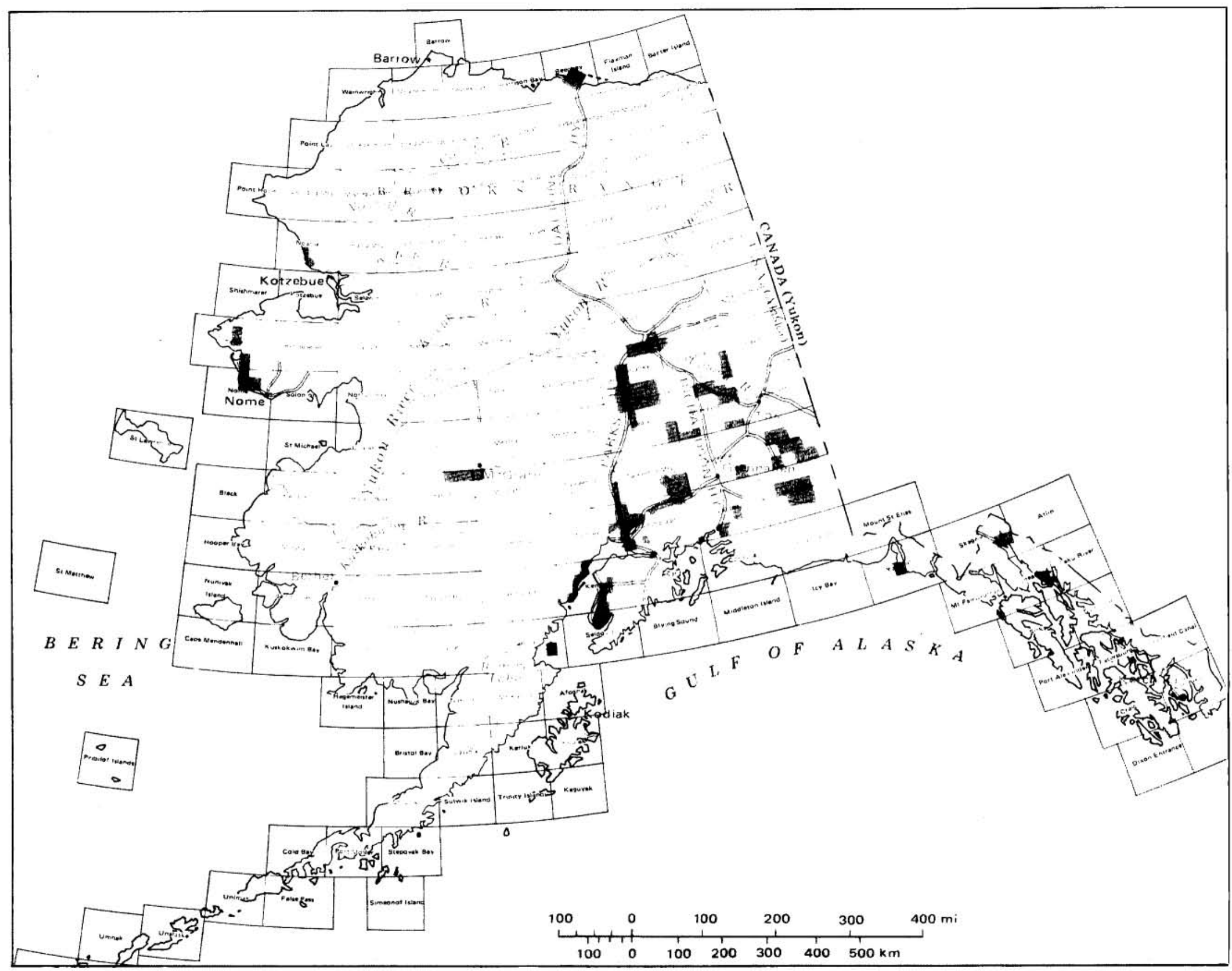

Figure 17. Areas of Alaska for which surficial-geologic maps were available in 1983 at scales useful for detailed land-use planning (1:63,360-scale maps or larger). 
Alaska" (Alaska Stat. 41.08.020a). Specifically, the law requires DGGS to "....collect, record, evaluate, archive, and distribute data on seismic events and engineering geology of the state; identify potential seismic hazards that might affect development in the state; and inform public officials and industry about potential seismic hazards that might affect development in the state" (Alaska Stat. 41.08.020b). The Engineering Geology Section of DGGS has primary responsibility for collecting data and publishing reports on engineering geology and seismic and geologic hazards. The Water Resources Investigations Section publishes surfacewater maps and reports that include streamflow hydrographs, runoff, and flood-plain maps to evaluate flood hazards. The Minerals Investigations and Geologic Map. ping Sections produce mineral-potential maps and general-purpose geologic maps that are also useful for identifying geologic hazards and locating sources of construction materials.

An ongoing task of DGGS is to prepare large-scale maps of surficial geology. These maps are currently available for only about 7 percent of the state (fig. 17), Because most construction not only takes place on recently deposited sediments, but also makes extensive use of these sediments (primarily sand and gravel), DGGS prepares surficial-geologic maps with three objectives: 1) to locate sources of construction materials; 2) to provide engineering-geologic information for construction and land use; and 3) to advance knowledge of the geologic history of Alaska. Such maps have been prepared for portions of the lower Matanuska Valley and Susitna valley, the Kenai lowlands, and the Anchorage bowl; maps are being prepared for the Haines-Skagway area, the Chugach Mountains, and parts of the North Slope at scaies of $1: 63,360$ and $1: 24,000$. Additional maps are planned for other developing areas and transportation corridors.

The DGGS has begun to prepare special-purpose reports and maps on engineering-geologic problems of selected areas that are of particular concern. Recently published examples include a comprehensive report on geologic hazards in the Fairbanks area (Péwé, 1982); an atlas of snow-avalanche paths along the Seward Highway (March and Robertson, 1983); subsurface-structure maps of the Bootlegger Cove Formation beneath Anchorage (Ulery and Updike, 1983); a report on the potential for earthquake-induced liquefaction in the FairbanksNenana area (Combellick, 1984); and a report on liquefaction-susceptibility analyses of sediments in Knik Arm and upper Turnagain Arm (Updike, 1984). Reports in preparation include an engineering assessment of the Turnagain Heights landslide area in Anchorage, an engineering-geology map of southwest Anchorage, and an atlas of snow-avalanche paths along the Richardson High way.

In FY $1984^{5}$, the Legislature established a statewide seismic-hazard program within DGGS. This program was

\footnotetext{
5 The fiscal year for the State of Alaska is July 1 to June 30.
}

primarily initiated because of a major decline in federal support for earthquake monitoring in Alaska and because long-term, continuous monitoring of earthquakes is essential for seismic-hazard evaluation. The program supports seismograph networks and building instrumentation to directly monitor earthquakes, compile and analyze old and new data, and publish quarterly and annual earthquake bulletins. State funding of these seismograph networks partially compensates for a recent dramatic decrease in federally supported networks. Only one network, which is operated by the USGS in south-central and southeastern Alaska, is supported by the federal government. Seismologic studies of some areas, particularly in interior regions away from major seismic regions, must still be based on limited existing data. For many areas of the state, reliable earthquake data either do not exist, or are available over such a short or discontinuous time period that they are inadequate for evaluating earthquake hazards (J.N. Davies, oral commun., 1982).

Occasionally DGGS is asked to participate on review panels or in special studies that involve other state agencies or local governments to address geologic problems associated with a major facility or hazard. One recent example is DGGS's participation on a geotechnical committee to make recommendations on the Pillar Mountain landslide near Kodiak that was identified by the USGS and Alaska Department of Transportation and Public Facilities (DOT/PF) in 1977. The geotechnical committee was formally established by a resolution passed by the Kodiak Island Borough and City of Kodiak in 1978. Another example is DGGS's involvement in site evaluation for the new state office building in Anchorage in response to a request from the Office of the Governor. Public institutions, private companies, and the general public also request information and assistance from DGGS.

\section{UNIVERSITY OF ALASKA}

In FY 1983, the University of Alaska received about 53 percent of its total research funding from the State of Alaska. Approximately 43 percent of the total was from the state general appropriation to the university and the remaining 10 percent was from state research contracts on specific topics (University of Alaska, 1983). During FY 1982 and the first half of FY 1983, the Geophysical Institute, which performs most of the university's research on geologic and geophysical hazards, received approximately 36 percent of its total operating funds from the state. However, state research contracts for specific topics, including geologic hazards, constituted only about 7 percent of the institute's budget (University of Alaska Geophysical Institute, 1982), and less than 2 percent was for research on geologic hazards.

The federal government provided over 60 percent of the university's research funding until FY 1982. A major 
part of the federal funding was for studies of geological and geophysical hazards associated with oil development on the outer continental shelf. Many of these projects, particularly those dealing with earthquake hazards, also provided useful data for coastal and interior areas of the state. Federal funding for geologic-hazards projects has been largely terminated, with the exception of limited support to study sea ice and permafrost.

When federal reductions severely impacted university-operated seismograph networks in Alaska, the state appropriated about $\$ 140,000$ for the (ieophysical Institute to operate one regional network in FY 1983. The support came from a $\$ 20$ million 'impact fund' created by President Reagan to provide relief to programs affected when federal responsibilities were transferred to the states. This was a one-time appropriation that maintained the seismic network through June 1983. In July 1983, the Geophysical Institute began to receive partial support for its seismic networks through the DGGS seismic-hazard program, funded by special appropriation in FY 1984. In FY 1985, the seismichazard program was incorporated into the state operating budget at a reduced level.

\section{ALASKA COUNCIL ON SCIENCE AND TECHNOLOGY}

By September 1982, the Alaska Council on Science and Technology (ACST) had provided $\$ 632,935$ for geologic-hazard studies out of a total of $\$ 3,035,641$ spent on research activities since the council was formed by the Legislature in 1979. Snow avalanches, earth. quakes, volcanoes, permafrost, and coastal-flooding hazards were studied. The ACST also convened two workshops to assess the status of research on hazards in Alaska and make recommendations for improved federal and state policy on supporting hazards studies (Alaska Council on Science and Technology, 1980a,b). The Legislature terminated funding for $A \operatorname{CSS}^{\top} \mathrm{T}$ at the end of FY 1984

Two major problems prompted $\Lambda$ CST workshops on hazards: the reductions in federal funding for hazards studies and the lack of state policy on hazard mitigation. State research funding for $\mathrm{ACS} T$ was distributed among many scientific disciplines, and the amount available for hazards studies was inadequate to compensate for the major cutbacks in federal funds. The ACST supported short-term projects to address specific topics but, without state support, was reluctant to fund projects like seismograph networks that require long-term commitments to be cost effective. The Working Group on Alaskan Seismology recognized the advantage of state participation in federally funded earthquake-hazardevaluation programs and recommended immediate state action to fund earthquake studies and develop a comprehensive state policy for seismic safety (Alaska Council on Science and Technology, 1980b). Some subsequent funding decisions made by ACST and the FY 1983 special appropriation made by the Legislature from the 'impact fund' were based on these recommendations, but no long-term state policy for hazard mitigation has been adopted.

\section{CONCLUSIONS}

Major geologic events will continue to occur in Alaska and, with increased development, affect more people and property. Earthquakes, volcanic eruptions, landslides, snow avalanches. floods, and related occurrences, such as tsunamis, seiches, mudflows, and secondary ground failures, are inevitable. The extent of property damage and injury associated with an event will depend not only on its location and severity, but also on how well the potential effects have been anticipated during planning and development. Although more continuous or localized processes like thaw settlement, soil creep, frost heave, and erosion may not be as disastrous, they may be just as costly over the long term unless susceptible areas are identified and potential problems are considered in selecting construction sites and designing facilities.

Although the State of Alaska has significantly im. proved its disaster-response and disaster-relief capabilities since the 1964 earthquake, there is a need to consider possible improvements in hazard mitigation (measures to reduce the potential for property damage and injury from natural events and, consequently, to reduce dependence on disaster relief). Technology is available to delineate natural hazards, determine their severity, and reduce their potential effects on people and property. On the basis of this review of national and state policies, 10 issues are proposed for considering possible improvements in hazard-mitigation policy in Nlaska:

1. Policy guidance and coordination of state and local hazard-mitigation programs.

2. Availability of basic technical information on hazards for land-use planning and construction.

3. Continuation of federally funded hazards studies that are being terminated or substantially reduced.

4. Incentives and guidelines to consider geologic: hazards in local plans and ordinances.

5. Hazard mitigation in siting, design, and construction of critical facilities.

6. Hazard mitigation in siting, design, and construction of many state-funded public facilities.

7. The relationship between hazard-mitigation and eligibility for disaster-relief funds.

8. Capability of state agencies to provide adequate technical services, assistance, and project reviews on geologic hazards for other agencies and local governments.

9. Standards of experience and education for feologists who prepare reports required by state or local laws for siting or designing facilities.

10. State capability to issue formal notices of serious geologic hazards and to coordinate the response by state and local agencies. 
Successful hazard-mitigation programs in other states can serve as models for new or improved programs in Alaska. Certain attributes of federal programs that have suceeded in promoting hazard mitigation could also be incorporated in state programs. However, new programs in Alaska must be tailored to the state's unique political structure, demography, social attitudes, and existing laws. For example, a statewide building code may not be a reasonable approach to hazard mitigation in Alaska because many local governments are not equipped to establish rigorous review procedures or inspection programs for their jurisdictions. Regulation of all construction in the vast remote areas of the unorganized borough would be logistically impossible. On the other hand, regulation of the construction of critical facilities and certain state-financed projects in hazardous areas is feasible.

Hazard-mitigation programs in California and Colorado were reviewed to determine their possible applicability in Alaska. These two states were chosen because of their extensive, successful programs and because their geologic environments and problems are similar to those in Alaska. Many factors contribute to the success of hazard-mitigation programs in California and Colorado and of some federal programs:

1. Strong policy guidance and coordination by a single state agency or commission.

2. Availability of adequate technical information to identify and evaluate hazards and determine design standards.

3. Encouragement of better awareness and appreciation of hazards among local officials through incentives or requirements to consider hazards in local comprehensive plans and ordinances.

4. Protection of local governments from damage liability for actions taken in good faith to mitigate geologic hazards.

5. Availability of guidelines and criteria to recognize and mitigate hazards at the local level.

6. Centralized and standardized review of design and construction plans and supporting information for certain critical facilities and most public facilities.

7. Appropriate, clearly defined design and performance standards for facilities subject to review for hazards safety.

8. Adequate training and experience of reviewers in geology, hydrology, seismology, or engineering, depending on the review task.

9. Inclusion of incentives or requirements for hazard mitigation as part of disaster-relief programs.

10. Ability of programs to be self supporting through special permit or license fees (as with the California Strong-motion Instrumentation Program).

\section{RECOMMENDATIONS FROM THE WORKSHOP ON EVALUATION OF REGIONAL ANI) URBAN EARTH- QUAKE HAZARISS ANI) RISK IN ALASK A}

The U.S. Geological Survey, in cooperation with DGis and other agencies, conducted a workshop in Anchorage, September 5-7, 1985, to assess the current state of knowledge of earthquake hazards in Alaska and advances in mitigation and preparedness since the 1964 Great Alaska Earthquake. Participants included seismologists, geologists, planners, emergency coordinators, policymakers, and educators that represent all levels of government, the private sector, and academia.

Workshop participants discussed the 10 issues that resulted from the analyses of this report for possible improvements in hazard-mitigation policy (see p. 59). Nine recommendations were unanimously adopted to address these issues.

\section{RECOMMENDATION 1 - ALASKA NA'TURAL HAZARDS SAFE'TY COMMISSION}

That a commission be established by the Legislature to provide policy guidance for the Governor and Legislature and help coordinate agency programs in natural hazards. Specific duties of the proposed commission (to be administered by the Office of the Governor) include recommending goals, priorities, and policies for hazard mitigation in the public and private sectors; developing legislation; disseminating public information; assisting in coordinating hazard-mitigation activities at all levels of government; and evaluating and issuing hazard warnings. Members should represent state, federal, and local governments and the private sector in the fields of geology, seismology, hydrology, geotechnical engineering, structural engineering, planning, and emergency services. A bill to establish the Alaska Natural Hazards Safety Commission was introduced in the Alaska Senate on May 6, 1985 (app. A).

\section{RECOMMENDATION 2 - STATE POLICY FOR HAZARD MITIGATION}

That the Governor and Legislature develop policies for hazard mitigation in Alaska that establish long-term commitments and goals:

A. Recognition of state responsibility for the safety of its citizens from major natural hazards and for taking reasonable measures to reduce the loss of life, injury, and property damage.

B. A commitment to ensure long-term financial support for hazard monitoring, mapping, and mitigation, including funding for local govern- 
ments to develop and maintain risk-reduction programs.

C. A statement of the roles and responsibilities of state and local governments in hazard mitigation that outlines the hazard issues to be relegated to cities and boroughs vs. those of statewide significance (for example, critical facilities and regional hazards) for which state government will retain responsibility.

1). A declaration of state-agency responsibilities and duties for collecting and disseminating technical information on hazards: providing technical. planning, and legal assistance to local governments; regulating construction of critical facilities; reviewing design plans for state. regulated facilities; administering local planning-assistance funds: helping prepare local disaster-preparedness plans; evaluating hazards to state facilities; and managing state hazard. monitoring programs and hazard-warning systems.

\section{RECOMMENIDATION 3 - HAZARD- MONITORING: PROGRAM}

That the state establish and support a program that ensures availability of basic data needed to evaluate geologic hazards. Included in the proposed program is a minimal network of seismic-monitoring devices to complement those of the federal government. Support for periodic instrument maintenance, transmission of seismic records to processing facilities, and processing and cataloging of data is necessary. Support for scientists to respond quickly to a significant event. collect data. and evaluate immediate dangers is also necessary.

Although operation of the overall hazard-monitoring program will require a long-term financial commitment, hazard-evaluation studies can be conducted on a project-specific basis. State commitment to a hazard. monitoring program will ensure that data are available for hazard evaluation when needed.

\section{RECOMMENDATION 4 - AMENDMENTS TO THE MUNICIPAL CODE (ALASKA STA'T. 29) AND O'THER S'TATU'TES TO PROMOTE LOCAL-GOVERN- MEN'T AC'TION IN HAZARD MITIGATION}

That amendments authorize or require considera tion of geologic hazards in local comprehensive plans, building codes, and ordinances; provide for state financial and planning assistance to help local governments exercise this authority; reduce liability of local governments from hazard-related damages based on lawful actions taken to mitigate hazards; and require that state agencies provide guidelines and technical assistance.
RECOMMENI)ATION 5 - STAATE REGULATION OF CONSTRUCTION ANI) MAJOR AL'TERA'TION OF CRITICAL, FACILITIES

That critical facilities be reasonably protected from threat by natural processes. Because public health and safety are state responsibilities, state regulation of construction and major alteration of critical facilities is necessary. Existing regulations for safety of dams and health facilities from geologic hazards should be re. viewed to be consistent with this recommendation, and new legislation or regulations should be considered to address other important facilities.

Programs to reduce the vulnerability of eritical facilities to geologic hazards have four essential components:

A. Requirements for geologic and engineering investigations of the proposed site to evaluate potential geologic hazards and determine maximum probable and. in some cases. maximum eredible events.

B. A requirement that siting and design plans for construction or major alteration consider the identified hazards in accordance with design or performance standards established by law for the type of facility in question and that plans be prepared by registered architects or struc. tural engineers.

C. A requirement for central review and approval of the plans and reports by a designated state agency according to facility type (for example. regulation of hospital construction by the Division of State Health Planning and Develop. ment, dams by the Division of Land and Water Management, critical utilities by the Alaska Public Vitilities Commission, or airports by the Department of Transportation and Public Facilities). The review and permitting agency should have the authority to establish inter. ageney or external boards of consultants to assist in the review process or require independent review by a registered structural engineer and a certified professional geologist.

D. A requirement for verification by site inspection that construction complies with the approved plans.

\section{RECOMMENDATION 6 - HAZARD- MI'TIGATION REQUIREMEN'TS FOR CERTAIN CAPITAL CON- STRUC'TION PROJEC'TS}

That capital-construction projects financed by the state be subject to minimum standards to protect life and property from geologic hazards. These requirements 
should apply to construction projects that are performed direetly by or under the supervision of state agencies and local construction projects that are financed with state capital-improvement funds. State policymakers, on the advice of the proposed Natural Hazards Safety Commission (Recommendation 1), should determine which projects are subject to these requirements. Regulated projects should include state-funded facilities that pose a significant risk to public safety if damaged. Examples include state-office buildings. state-financed municipaloffice buildings, state-financed indoor-recreation facilities, and state-financed housing complexes. Examples of state-funded facilities that may not be subject to these regulations include warehouses, grain-storage facilities. roads, and parks. Critical facilities constructed with capital-improvement funds should be subject to the more stringent requirements and state-level review proposed in Recommendation 5.

Before a regulated facility is constructed or has major structural alterations, a geologic and engineering site analysis is necessary to identify potential geologic hazards and determine how safe the site is for the proposed use. In addition, a review of design and construction plans is necessary to verify that they conform with applicable codes and ordinances and that identified hazards have been adequately considered. The state ageney or local government that administers the project should be responsible for implementing the requirements and reviewing and certifying the reports and plans before construction.

\section{RECOMMENIOATION 7 - CONDITIONAL, AVAILABILITY OF DISAS'TER-RELIEF FUNDS TO PROMO'TE HAZARI) MITIGATION}

That state statutes that provide community disaster relief in the form of grants or loans include positive incentives or requirements for hazard mitigation. Unconditional availability of relief funds for declared disasters may act as an incentive against mitigation measures. There are two general ways in which these in. centives or requirements can be applied.

A. Increase state disaster-relief benefits available to local governments that adopt comprehensive hazard ordinances.

B. Require that local governments incorporate hazard-mitigation measures in postdisaster reconstruction to minimize damage from similar future events as a condition for receiving disaster-relief funds.

\section{RECOMMENDATION 8 - IMPROVED \\ CAPABILITIES FOR STATE AGENCIES \\ TO PROVIDE TECHNICAL ASSISTANCE \\ TO O'THER AGENCIES AND LOCAL GOVERNMENT'S IN HAZARD MITIGATION ANID DISASTER PREPAREDNESS}

That appropriate state ageneies be provided with sufficient funding and flexibility to respond to requests from other agencies and local governments for technical or planning assistance, including performance of routine reviews and participation in special review boards. Flexibility of project budgets (including the establishment of contingency funds) is necessary to provide for unantici pated needs. State agencies that request the assistance or participation of other agencies on review boards may compensate for services through reimbursible services agreements.

\section{RECOMMENDATION 9 - STTA'TE HAZARD-NO'TIFICATION SYS'TEM}

That the state adopt a hazard-notification system to supplement that of the U.S. Geological Survey. Appro. priate state agencies should recommend issuance of notices and supply supporting information to the proposed Natural Hazards Safety Commission (Recom. mendation 1). The Commission should review the recommendations, evaluate possible socioeconomic consequences, and advise the Governor, Legislature, state agencies, and local governments about appropriate responses, defensive actions, and funding alternatives. The state should be prepared to compensate for adverse socioeconomic impacts of hazard notifications through existing disaster-relief programs.

\section{ACKNOWLEDGMENTS}

Much of the information used to prepare this report came from personal discussions with the individuals listed below ${ }^{6}$, most of whom are closely involved with hazard-mitigation programs at the local, state, and federal levels. I thank them for sharing their personal knowledge, opinions, and suggestions.
J.L. Aho
R.A. Andrews
G.W. Carte

CH2M Hill, Inc. (Anchorage. Alaska) Seismic Safety Commission, State of California

Alaska Tsunami Warning Center (National Oceanic and Atmospheric Administration) and Mayor of Palmer

\footnotetext{
${ }^{6}$ Affiliations in 1982 .
} 
J.N. Davies

C.L. Davis

J.F. Davis

'T.E. Gay, Jr.

Ron Goldberg

S.B. Hardy

Paul Jenke

W.R. Junge

S.F. Mack

G.D. March

Jim McCalpin

J.F. Meehan

Shirley Meudt

C.L. Miller

J.L. Mintier

Tim Mittendorf

Paul Morrison

R.A. Page

W.W. Peak

Vern Persson

R.D. Reger

J.R. Riehle

W.P. Rogers

Phil Schmuck

L.L. Selkregg

J.M. Soule

D.W. Sprague

P.A. Stromberg

Dennis Thomason

R.G. Updike
Division of Geological and ( Feophysical Surveys. State of Alaska

State Fire Marshal's Office (Fairbanks). State of Alaska

Division of Mines and (irology, State of California

Division of Mines and (ieology, State of California

Division of State Health Planning and

Development. State of Nlaska

Division of Geological and (ieophysical Surveys, State of Alaska, and Planning Commission. Fairbanks North Star Borough

Division of Land and Water Management, State of Alaska

Colorado (ieological survey

Division of Land and Water Manage. ment, State of Alaska

Division of (ieological and Geophysical Surveys, State of Alaska

Jefferson County, Colorado

Office of the State Architect, State of California

Division of Emergency Services. State of Alaska

Division of Municipal and Regional Assistance, State of Alaska

Office of Planning and Research, State of California

Fairbanks North Star Borough

Department of Water Resources. State of California

U.S. Geological Survey

Division of Safety of Dams, State of California

Division of Safety of Dams, State of California

Division of Geological and Geophysical Surveys, State of Alaska

U.S. Geological Survey

Colorado Geological Survey

Department of Local Affairs, State of Colorado

University of Alaska, Anchorage, and Anchorage Municipal Assembly

Colorado Geological Survey

State Mining and Geology Board, State of California

Seismic Safety Commission, State of California

Division of Emergency Services, State of Alaska

Division of Geological and Geophysical Surveys, State of Alaska, and Anchorage Geotechnical Advisory Commission
Ron Watts

Leila Wise

T.M. Wootton

Building Department. Municipality of Anchorage

Department of Natural Resources. State of Alaska

Office of Strong Motion Studies. California Division of Mines and (ieology

I especially thank (iay and Junge for arranging and coordinating meetings and interviews in their respective states and Reger for initiating this project and providing many valuable references and suggestions. The report was reviewed by Reger. Lipdike. Selkregg. and Miller. Selected sections of the document were reviewed by Hardy. March, and Davies.

\section{REFERENCES CITED}

Alaska Council on Science and Technolongy, 1980)a, Alaska natural hazards: Research prorities and recommendations: Juneatu, $7 \mathrm{p}$.

19801, Alaskan seismology: Research priorities and recommendations: Juneau, $6 \mathrm{p}$.

Alaska Department of Labor, 1983, Alaska population overview, 1982: Juncau, $116 \mathrm{p}$

Alfors, J.T., Burnetl, J.L., and Gay, T.E., Jr., 1973 , Urban geology master plan for California: Sacramento, California Division of Mines and Geology Bulletin 198, 112 p.

Amimoto, P.Y., 1974, Review of new hospital sites for seismic safety: Sacramento, Californiat Geology. v. 27, no, $5, p .110-113$.

Baker, E.J., and McPhee, J.G., 1975, Land use management and regulation in hazardous areas: A research assessment: Boulder, University of Colorado Institute of Behavioral Science, Program on Tech nology, Environment and Man Monograph NSF. $\mathrm{RA} \cdot \mathrm{E}-75 \cdot(0) \mathrm{8}, 12+\mathrm{p}$

Burton, lan, Kates, R.W., and White, G.F., 197x, The environment as hazard: New York, Oxford Univer sity Press, $240 \mathrm{p}$.

California Division of Mines and Geology, 1976, Second report on the Strong-Motion Instrumentation Program: Sacramento, Special Publication 48, $39 \mathrm{p}$. 1979. California surface mining and reclamation policies and procedures: Sacramento, Special Publication 51, 10 p.

California Office of Planning and Research, 1980 . General plan guidelines: Sacramento, $327 \mathrm{p}$.

California Seismic Safety Commission, 1977a, A review of the seismic salfety element requirement in California: Sacramento, Report SSC $77-01,31 \mathrm{p}$.

1977h, Report on local government imple mentation of the Special Studies Zones Act: Sacramento, $50 \mathrm{p}$.

1981, Anmual report to the Governor and the legislature for Jamuary 1980 - June 1981: Sacra mento, $25 \mathrm{p}$.

Camplell, Ian, 1976, The influence of geologic hazards on legislation in California: Sacramento, California Geology, v. 30, no. 10, p. 219.22:3. 
Carter, Winn, 1983, The Utah Seismic Safety Advisory Council, in Hays, W.W., ed., A workshop on the 1886 Charleston, South Carolina earthquate and its implications for today: U.S. Geological Survey Open-lile Report 83.043, p. 356-359.

Colorado Land Use Commission, 1976, House bill 10.41 - Model land use regulations: Denver, $345 \mathrm{p}$.

1981, Land use planning in Colorado: Denver, unpublished report, $10 \mathrm{p}$.

Combellick, R.A., 1984, Potential for earthquakeinduced liquefaction in the Fairbanks-Nenana area, Alaska: Alaska Division of Geological and Geophysical Surveys Report of Investigations 84-5, $10 \mathrm{p}$, scale $1: 250,000,1$ sheet.

Council of State Governments, 1972, Fxample state disaster act of 1972; suggested state legislation: Lexington, Kentucky, v. 32, p. 104-128.

1979, The states and natural hazards: Lexington, Kentucky, $99 \mathrm{p}$.

Cox, D.C., and Pararas-Carayannis, George, 1976, Catalog of tsunamis in Alaska, revised by J.P. Calebaugh: Boulder, Colorado, World Data Center for Solid Earth Geophysics, National Oceanic and Atmospheric Administration Report SE-1, $43 \mathrm{p}$.

Davies, J.N., 1983, Seismic, volcanic, and Isunami mitigation in Alaska. An unmel need: Alaska Division of Geological and Geophysical Surveys Report of Investigations 83-11, 13 p.

Decker, Robert, and Decker, Barbara, 1981, The eruptions of Mount St. Helens: Scientific American, v. 244, no. 3 , p. $68-80$.

EERI Committee on Seismic Risk, 1984, Glossary of terms for probabilistic seismic-risk and hazard analysis: Earthquake Spectra, v. 1, no. 1, p. 33.40.

Federal Emergency Management Agency, 1982, Federal disaster-relief funding for Alaska, January 1960 to January 1982: Seattle, Washington, unpublished data, $23 \mathrm{p}$.

Fredston, J.A., and Sweet, L.R., 1985, Seward Highway avalanche data base: Alaska Department of Transportation and Public Facilities Research Notes, v. 5, no. 3,2 p.

Hamilton, R.M., 1978 , Earthquake hazards reduction program - Fiscal year 1978 , Studies supported by the U.S. Geological Survey: U.S. Geological Survey Circular $780,36 \mathrm{p}$.

Hart, E.W., 1975, Guidelines for evaluating the hazard of surface fault rupture and suggested outline for geologic reports on faults: Sacramento, California Division of Mines and Geology Note 49, $2 \mathrm{p}$. 1980, Fault-rupture hazard zones in California: Alquist-Priolo Special Studies Zones Act of 1972 with index to special studies zones maps: Sacramento, California Division of Mines and Geology Special Publication 42, $25 \mathrm{p}$.

Hart, E.W., and Wagner, D.L., 1975, Investigations of surface faulting - A critique: Association of Engineering Geologists Abstracts, 18th Annual Meeting, p. 24 .

Hays, W.W., 1979, Program and plans of the U.S. Geological Survey for producing information needed in national seismic hazards and risk assess. ment, fiscal years 1980-84: U.S. Geological Survey Circular $816,40 \mathrm{p}$
Hays, W.W., and Shearer, C.F., 1981, Suggestions for improving decisionmaking to face geologic and hydrologic hazards, in Hays, W.W., ed., 1981, Facing geologic and hydrologic hazards - Earth science considerations: U.S. Geological Survey Professional Paper 1240-B, $108 \mathrm{p}$.

International Conference of Building Officials, 1980, Issues which affect the role of building departments in earthquake hazard mitigation: Whittier, California, p. 12-13.

1982, Uniform building code (revised ed.): Whittier, California, $780 \mathrm{p}$.

Ives, J.D., and Krebs, P.V., 1978, Natural hazards research and land-use planning responses in mountainous terrain: The town of Vail, Colorado, Rocky Mountains, U.S.A.: Arctic and Alpine Research, v. 10, no. 2 , p. $213 \cdot 222$.

Johnson, J.B., 1982, An evaluation of the Alaska Avalanche and Fire Weather Forecast System: Fairbanks, University of Alaska Geophysical Institute unpublished report to the Alask a Division of Geological and Geophysical Surveys, $57 \mathrm{p}$.

Joint Federal-State Land-Use Commission, 1979, Summary of major land issues in Alaska: Anchorage, Published Report 39, $128 \mathrm{p}$.

Junge, W.R., and Shelton, D.C., 1978, The geological review process: Denver, Colorado Geological Survey, $4 \mathrm{p}$

Leighton, F.B., 1982, Overcoming landslide hazards: Professional Surveyor, v. 2, no. 3, p. 16-26.

Mann, A.E., 1979, The Field Act and California schools: Sacramento, California Seismic Safety Commission Report SSC 79-02, 77 p.

March, G.D., and Robertson, L.G., 1982, Snow avalanche atlas, Seward Highway, south-central Alaska: Alaska Division of Geological and Geophysical Surveys Professional Report 81, 168 p., scale $1: 63,360,3$ sheets.

Meyers, Herbert, 1976, A historical summary of earthquake epicenters in and near Alaska: National Oceanic and Atmospheric Administration Technical Memorandum EDS NGSDC-1, 57 p.

Miller, D.J., 1960, Giant waves in Lituya Bay, Alaska: U.S. Geological Survey Professional Paper 354-C, $86 \mathrm{p}$.

Miller, R.D., and Dobrovolny, Ernest, 1959, Surficial geology of Anchorage and vicinity, Alaska: U.S. Geological Survey Bulletin 1093, 128 p., scale $1: 63,360,6$ sheets.

Miller, T.P., 1976, Augustine Volcano: Alaska Geographic, v. 4, no. 1, p. 17-28.

Mintier, J.L., and Stromberg, P.A., 1982, Seismic safety at the local level: Does planning make a differ ence?: Sacramento, California Seismic Safety Commission, $26 \mathrm{p}$.

National Research Council, 1973, The great Alaska earthquake of 1964 . Summary and recommendations: Washington, National Academy of Sciences, $291 \mathrm{p}$.

Nichols, D.R., and Campbell, C.C., eds., 1971, Environmental planning and urban geology: Washington, U.S. Department of the Interior and U.S. Department of Housing and Urban Development, $204 \mathrm{p}$. 
Office of Emergency Preparedness, 1972, Disaster pre paredness: Report to Congress: Washington, D.C., v. $1,18.4 \mathrm{p}$

Olson, R.A., and Scott, Stanley, 1980, Preparing for earthquakes: Where does California stand?: Berke ley, University of California Institute of Governmental Studies California Data Brief, v. 4, no. 3, $6 \mathrm{p}$.

Péwé, T.L., 1982, Geologic hazards of the Fairbanks area, Alaska: Alaska Division of Geological and Geophysical Surveys Special Report 15, 109 p.

Reed, K.M., ed., 1981, The U.S. Geological Survey in Alaska, 1981 programs: U.S. Geological Survey Circular $8.43,111 \mathrm{p}$.

Rogers, W.P., Ladwig, L.R., Hombaker, A.L., Schwo chow, S.D., Hart, S.S., Shelton, D.C., Seroggs, D.L. and Soule, J.M., 1974, Guidelines and criteria for identification and land-use controls of geologic and mineral resource areas: Denver, Colorado Geological Survey Special Publication 6, $1.46 \mathrm{p}$.

Rold, J.W., 1978, The communication of information for geologic-hazard mitigation - The Colorado example: Public meeting, Denver, Colorado, unpublished report prepared for public meeting on May 15, 1978, 14 p.

Rollins, A.M., 1978, Census-Alaska: Number of in habitants, 1792-1970: Anchorage. University of Alaskit, $117 \mathrm{p}$.

Schnell, M.L., and Herd, D.G., 198:3, National Earthquake Hazards Reduction Program: Report to the U.S. Congress - Overview: U.S. Geological Survey Circular $918,65 \mathrm{p}$.

Scott, Stanley, 1981, Independent review of critical facilities, with special emphasis on state-federal relationships and dam safety: Sacramento, California Seismic Safety (ommission Report SSC-81-1)1, $55 \mathrm{p}$

Seed, H.B., and Wilson, S.D., 1966, The Turnagain Heights landslide in Anchorage, Alaska: Berkeley, University of California Soil Mechanics and Bituminous Materials Research Laboratory, $37 \mathrm{p}$.

Selkregg, L.L., Crittenden, E.D., and Williams, Norman $\mathrm{J}_{\mathrm{r}}, 1970$, Urban planning in the reconstruction, in The Great Alaska Earthquake of 196.4, Human Ecology Volume: Washington, National Research Council, National Academy of Sciences, p. $186 \cdot 242$.

Selk regg, L.L., Ender, R.L., Johnson, S.F., Kim, J.C.K., Gorski, S.F., Preuss, Jane, and Kelso, Duncan, 1984, Seismic hazard mitigation: Planning and policy implementation. The $\Lambda$ laska case: Anchorage, University of $\mathrm{Alask}$ a, $332 \mathrm{p}$.

Slosson, J.E., 1975, Legislation related to earthquakes: Sacramento, California Geology, v. 28, no. 2, p. 37.

Stewart, R.M., Hart, E.W., and Amimoto, P.Y., 1977. The review process and the adequacy of geologic re- ports: Sacramento, Calilornia Geology, v. 30, no. $10, p, 221-229$

Tarr, R.S., and Martin, Lawrence, 1912, The earthquakes at Yakutat Bay, Alaska, in September, 1899 U.S. Geological Survey Professional Paper 69, $23 . \mathrm{p}$.

Troxel, B.W., 1982, Limit of the law (letter to the editor): Geotimes, v. 27, no. 3, p. 9-10.

Turner, R.H., Nigg, J.M.. Heller Paz, Denise, and Shaw Young, Barbara, 1979, Earthquake threat: The human response in southern California: Los Angeles, University of California Institute for Social Science Research, p. 92

1981). Community response to earthquake threat in southern Callfornia: Los Angeles, University of California Institute for Social Science Re search, Part 5, p. 6.4-70.

Ulery, C.A., and Updike, R.G., 1983 , Subsurface structure of the cohesive facies of the Bootlegger Cove Formation, southwest Anchorage, Alaska: Alaska Division of Geological and Geophysical Surveys Professional Report 84 (in cooperation with the U.S. Geological Survey Office of Earthquake studies), 5 p., scale $1: 15,840,3$ sheets.

Updike, R.G., 1984, Liquefaction-susceptibility analysis for foundation soils, Knik River bridge, Glenn Highway, Alaska: Alaska Division of Geological and Geophysical Surveys Report of Investigations 84-26 (in cooperation with the U.S. Geological Survey Office of Earthquake Studies), $33 \mathrm{p}$.

University of Alaska, 1983, Research annual report, 1981-82: Fairbanks, 121 p.

University of Alaska Geophysical Institute, 1982, Annual report, 1981-82: Fairbanks, $254 \mathrm{p}$.

U.S. Geological Survey, 1977, Warning and preparedness for geologic-related hazards: Federal Register, v. 12, no. 7()$, p. $19292-19296$.

1981, Goals, strategies, priorities and tasks of a national landslide hazard-reduction program: U.S. Geological Survey Open-file Report 81-987, $91 \mathrm{p}$. 1984 , Revision of terminology for Geologic Hazard Warnings: Federal Register, v. 49, no. 21, p. $3938-3939$.

White, G.F., and Haas, J.E., 1975, Assessment of research on natural hazards: Cambridge, Massachuselts, The MIT Press, $487 \mathrm{p}$.

Woodward-Clyde Consultants, 1980a, Assessment of review processes for seismic safety in California: San Francisco, unpublished report prepared for the California Seismic Safety Commission, $44 \mathrm{p}$. $198(0), \Lambda$ ssessment of public policy regarding lifelines and critical facilities in California: San Francisco, unpublished report prepared for the California Seismic Safety Commission, 2 v., 115 p. 
Introduced: $5 / 6 / 85$

Referred: State Affairs

and Finance

IN THE SENATE

BY STURGULEWSK1, V. FISCHER, RODEY AND ZHAROFF

\author{
SENATE BILL NO. 310 \\ IN THE LEGISLATURE OF THE STATE OF ALASKA \\ FOURTEENTH LEGISLATURE - FIRST SESSION
}

\title{
A BILL
}

For an Act entitled: "An Act establishing the Alaska Natural Hazards Safety Commission."

BE IT ENACTEI) BY THE LEGISLA'TURE OF THE STATE OF ALASKA:

Section 1. FINDINGS. The legislature finds that

(1) although the state has made significant improvements in disaster preparedness since the great earthquake of 1964 , there has been little corresponding improvement in measures to reduce the disaster potential of natural hazards and, consequently, to reduce dependence on disaster relief;

(2) there is a pressing need to provide a consistent policy framework and a means for continuing coordination of hazard-related programs and public safety practices at all governmental levels and in the private sector; this need is not being addressed by any continuing state government organization;

(3) through concerted efforts coordinated by a Natural Hazards Safety Commission, the state can make long-term progress toward mitigating the effects of natural hazards on persons and property, thereby reducing the costs of responding to and recovering from natural hazards.

Sec. 2. AS 44.19 is amended by adding new sections to read:

\section{ARTICLE 15. ALASKA NATURAL HAZARDS SAFETY COMMISSION.}

Sec. 44.19.241. COMMISSION ESTABLISHE1). The Alaska Natural Hazards Safety Commission is established in the Office of the Governor.

Sec. 44.19.242. MEMBERSHIP. (a) The commission is composed of 11 members appointed by the governor for terms of three years. A member holds office until a successor is appointed and confirmed. A vacancy is filled for the unexpired term. The governor shall appoint to the commission a representative from the University of Alaska, a representative from local government, a representative from the Department of Natural Resources, a representative from the Department of Military and Veterans' Affairs, a representative from an appropriate federal agency and shall appoint the remaining six members from members of the public who are knowledgeable in the fields of geology, seismology, hydrology, geotechnical engineering, structural engineering, emergency services, or planning.

(b) The commission shall elect annually from its members a chairman and vice-chairman. A majority of the commission may vote to replace an officer of the commission.

(c) Eight members constitutes a quorum.

(d) Commission members receive no compensation but are entitled to travel and per diem authorized for boards and commissions under AS 39.20.180. 
Sec. 44.19.243. POWERS AND DUTIES. (a) The commission shall

(1) recommend goals and priorities for hazard mitigation to the public and private sectors;

(2) recommend policies to the governor and the legislature, including needed research, mapping, and monitoring programs;

(3) offer advice on coordinating disaster preparedness and hazard-mitigation activities of government at all levels, review the practices for recovery and reconstruction after a natural disaster, and recommend improvements to mitigate losses from similar future events;

(4) gather, analyze, and disseminate information of general interest on hazard mitigation;

(5) establish and maintain necessary working relationships with other public and private agencies;

(6) review predictions and warnings issued by the federal government, research institutions, and other organizations and persons and suggest appropriate responses at the state and local level; and

(7) review proposed hazard notifications and supporting information from state agencies, evaluate possible socioeconomic consequences, recommend that the governor issue formal hazard notifications when appropriate, and advise state and local agencies of appropriate responses.

(b) The commission may

(1) advise the governor and the legislature on disaster preparedness and hazard mitigation and on budgets for those activities, and recommend legislation or policies to improve disaster preparedness or hazard mitigation;

(2) conduct public hearings;

(3) appoint committees from its membership and appoint external advisory committees of ex-officio members; and

dividuals.

(4) accept grants, contributions, and appropriations from public agencies, private foundations, and in-

Sec. 44.19.244 DEFINITIONS. In AS 44.19.241 - 44.19.244

(1) "commission" means the Alaska Natural Hazards Safety Commission;

(2) "disaster preparedness" means establishing plans and programs for responding to and distributing funds to alleviate losses from a disaster as defined in AS 26.23.230;

(3) "hazard mitigation" or "mitigation" mean activities that prevent or alleviate the harmful effects of natural hazards to persons and property, including identification and evaluation of the hazards, assessment of the risks, and implementation of measures to reduce potential losses before a damaging event occurs.

Sec. 3. AS $44.66 .010(a)$ is amended by adding a new paragraph to read:

(13) Alaska Natural Hazards Safety Commission (AS 14.19.241) June 30, 1989.

Sec. 4. Notwithstanding AS 44.19.242 enacted by sec. 2 of this Act, four of the initial members of the Alaska Natural Hazards Safety Commission shall serve terms of two years and three initial members shall serve terms of four years.

Sec, 5. Nothing in this Act is intended to transfer to the commission the authorities and responsibilities of other state agencies, boards, councils, or commissions or of local governments. 


\section{APPENDIX B}

\section{Glossary $^{7}$}

acceptable risk - A level of risk that can be accommodated without undue hardship and represents a realistic goal for design requirements for engineered structures.

active fault - a fault that, based on historical, seismological, or geological evidence, has a high probability of producing an earthquake.

avalanche - see debris avalanche, slushflow avalanche, and snow avalanche.

building code a document that specifies minimum design and construction requirements for structures.

calculated risk - the estimated total risk to a facility or the public that corresponds to a specific level of mitigation.

chronic hazard - a hazard that produces small, persistent or episodic changes in the earth's surface that may be minor over short periods of time, but may cause major damage to structures over long periods of time.

creep - slow, more or less continuous downsiope movement of soil or rock under gravitational stresses.

critical facility - a structure that houses or serves many people or otherwise poses unusually high hazards to public health and safety if the structure is damaged or malfunctions.

debris avalanche - a very rapid sliding or flowage of initially coherent soil and rock; a very rapid debris flow.

debris flow - a moderately rapid downslope flowage of soil, rock, and water that is triggered almost invariably by unusually heavy rain.

design criteria, design standards - minimum standards for layout, materials, structural properties, and construction of a facility (for example, building codes, design requirements in flood plains, or contract specifications).

design event - intensity of a natural event that is used as the basis for a structure's design.

design forces, design loads, design motions - static forces or motions at a site (for example, loads, displacements, velocities, or accelerations) that are used as the basis for a structure's design.

\footnotetext{
${ }^{7}$ Most definitions modified from Bates and Jackson, 1980 ; FERI Committee on Seismic Risk, 1984; and Woodward-Clyde Consultants, 19806.
}

disaster - an event that causes great harm to people or property over a short period of time.

disaster preparedness - plans, procedures, funds, facilities, and supplies established to respond to a natural disaster, distribute financial losses, and allow for an orderly recovery.

disaster recovery - the process of restoring services; relocating or rebuilding homes, businesses, and public facilities; and reestablishing normal social and economic activities.

disaster relief - provision of grants and loans to assist individuals, businesses, and state and local governments in recovering from a disaster.

disaster response - implementation of disaster-preparedness plans and other postdisaster activities (for example, search and rescule, debris removal, security, and provision of food, water, shelter, and medical aid) to restore public safety and facilitate recovery.

earthquake - a sudden motion or vibration in the earth caused by an abrupt release of energy.

fault - a fracture or fracture zone in the earth's crust along which there has been displacement of the sides relative to one another and paraliel to the fracture.

frost heaving - the uneven lifting and deformation of the ground surface that results from freezing of ground water and growth of ground-ice masses.

gelifluction - solifluction in an area underlain by frozen ground.

geologic hazard - a natural or man-made geologic condition that potentially endangers life and property (for example, landslide, earthquake, flood, volcanic eruption, ground subsidence, erosion, or snow avalanche).

geotechnical - pertaining to the application of information about the earth's crust and surface materials to solve civil-engineering problems.

hazard - see natural hazard.

hazard evaluation - data collection and analysis to identify and describe a natural hazard and determine its potential severity, the area affected, and probability of occurrence. 
hazard mitigation - poljcies and activities undertaken to prevent or minimize the likelihood of property damage and injuries from natural hazards (includes hazard evaluation, risk assessment, and hazard reduction).

hazard reduction - the application of technical information about hazards to develop policies and procedures for land use, facility design and construction, protection works, and warning systems to reduce the likelihood of property damage or injury.

heave - uneven uplift of the ground surface caused by expansion or displacement, such as from swelling clay. seepase pressure, or frost action.

intensity - a qualitative or quantitative measure of an event's severity at a specific site.

landslide - the perceptible, downward and outward sliding of soil, rock, and vegetation under gravitational influence.

magnitude (of an earthquake) - a measure of the strength or total energy released by an earthquake.

mappability - the relative ease of accurately locating or delineating a geologic hazard on a map at a scale appropriate for land-use planning (usually $1 \mathrm{~m}, \cdots 1 \mathrm{mi}$ or greater).

mass movement - the downslope displacement of a portion of the land surface as a unit, as in creep. land. slide, flow, or avalanche.

maximum credible event - the most severe event of a given type (for example. flood, earthquake, or landslide) that can be expected at a site, considering the known natural processes or conditions in the area.

maximum probable event - the most severe event of a given type (for example, flood, earthquake, or landslide) that can reasonably be expected to occur within the design life of a facility; often defined as the event that occurs once every $100 \mathrm{yr}$.

mitigation - see hazard mitigation.

mudflow - a rapid downslope flow of predominantly fine-grained material generally combined with a large amount of water; usually flows along an active or abandoned stream course.

natural hazard - a natural condition that may endanger life and property (includes all geologic hazards plus nongeologic conditions like drought. tornados, hail, forest fires, and lightning). nodal point - a location in a structure that vibrates very little relative to other locations at a given oscillation period during an earthquake.

nuéc ardente - a rapidly flowing, turbulent, gaseous cloud (sometimes incandesernt) that is erupted from a volcano; contains ash and other explosively ejected volcanic debris in its lower part.

performance criteria - minimum standards for the operational capabilities of a facility during and after an event of given intensity (for example, the services that a hospital must be capable of continuing after a major earthquake. or the volume of water that a dam must be capable of retaining during a $100 \cdot \mathrm{yr}$ flood).

protection works - structural improvements made in hazardous areas to limit the adverse effects of natural events (examples include flood-control dams and levees, retaining walls, slope-drainage svstems, refurbishing of old buildings against earthquake damage, and mobile. home anchoring systems).

pyroclastic flow - a rapidly moving, turbulent mixture of mostly fine-grained material and gas ejected explosively from a volcano.

residual risk - the difference between calculated risk and acceptable risk; represents the risk that can be reasonably reduced through mitigation.

risk - the probability of a given level of social or economic damage or loss resulting from one or more natural hazards based on the probability of the event occurring. its severity. location, and the probability that people or property will be adversely affected.

safety factor (engineering) - the ratio of a material's maximum strength (for example, soil, rock, concrete, or steel) to the probable maximum load to be applied to it.

seiche - oscillatory motion of a body of water in which the period of oscillation is determined by the dimensions of the containing hasin. Onshore runup of the resulting waves has been known to exceed elevations of 1,000 $\mathrm{ft}$.

seismic - pertaining to earthquakes or other natural or man-made vibrations in the earth.

siltation - accumulation of predominantly fine-grained sediment in a basin or behind a natural or man-made structure that obstructs the flow of sediment-laden water.

slushflow avalanche - a powerful flow of wet snow, soil, rock, and debris that occurs primarily in aretic and 
subarctic mountainous regions during rapid spring melting of the seasonal snow cover.

snow avalanche - the rapid falling or sliding of a large mass of snow that often incorporates considerable soil. rock, and debris.

solifluction the slow, viscous, downslope flow of water-saturated soil.

subsidence - uneven sinking of the ground surface caused by regional tectonic lowering of the crust or, locally, by collapse of underground solution cavities, melting of massive ground ice, soil compaction, or shrinking of clay-rich soils on drying.

tsunami - a large gravitational sea wave produced by a volcanic eruption or submarine earthquake.

volcanic bomb - a mass of expelled lava that is rounded like a bombshell as it falls.

warning system - a means of notifying the public of an impending catastrophic event so that preparations can be made, the area can be evacuated, and disaster-response plans can be implemented. 


\section{Acronyms}

AAFWFS - Alaska Avalanche and Fire Weather Fore. cast System

ACS'T - Alaska Council on Science and Technology

ADES - Alaska Division of Emergency Services

ASHA - Alaska State Housing Authority

BLM Bureau of Land Management (U.S.)

CEQA - California Environmental Quality Act

CGS - Colorado (ieological Survey

DEC - Department of Environmental Conservation ( Nlaska)

DES - Division of Emergency Services (Alaska)

DGGS - Division of Geological and Geophysical Surveys (Alaska)

DLWM - Division of Land and Water Management (Alaska)

DMG - Division of Mines and Geology (California)

DMRA - Division of Municipal and Regional Assistance (Alaska)

DNR - Department of Natural Resources (Alaska)

DOT/PF - Department of Transportation and Public Facilities (Alaska)

DSD - Division of Safety of Dams (California)

DWR - Department of Water Resources (California)

EHRP - Earthquake Hazards Reduction Program (U.S.)
FEMA Federal Emergency Management Agency

FERC Federal Energy Regulatory Commission

FNSB - Fairbanks North Star Borough

ICBO - International Conference of Building Officials

NOAA - National Oceanic and Atmospheric Administration (U.S.)

NSF - National Science Foundation

OMB - Office of Management and Budget (U.S.)

SCEPP - Southern California Earthquake Preparedness Program

SHAP Seward High way Avalanche Project. (Nlaska)

SHPI) Office of Statewide Health Planning and Development (California)

SMARA - Surface Mining and Reclamation Act (California)

SMGB - State Mining and feology Board (California)

SMIP Strong-motion Instrumentation Program (California)

SSC Seismic Safety Commission (California)

UBC - Uniform Building Code

USFS - U.S. Forest Service

USGS - U.S. (ieological Survey 
$\mathrm{ST}^{\prime} \mathrm{AFF}{ }^{1}$

Ross (i. Schaff. Director and State Geologist

William W. Barnwell. Deputy State Cieologist and Southcentral Regional Manager

Richard D. Reger. Northern Regional Manager

Wyatt G. Gilbert, Southeastern Regional Manager

Administrative Services

R.R. Jensen, Administrative officer ${ }^{2}$

D.J. Allen, Accounting clerk

P.1. Coonrod, Secretary

D.L. Hediell, Clerk ty pist

F.M. I amey, Administrative assistant

K. L. Maywood, Clerk tvpist.

.R.J. Michels, Supply technician

J.N. Newgaard, Accounting technician

C.A. Rawlinson, Clerk tv pist

.I.F. Richards, Clerk typist

.J.L. Weir, Clerk typist

M.F. Wright, Clerk typist

Archaeology

R.D. Shaw, Archaeologist ${ }^{2}$

R.G. Buzzell, Historian

.R.G. Dixon, Archaeologist

D.F. Gibson, Archaeologist

C.F. Holmes, Archacologist

.S.L. Klingler, Archaeologist

I.D. McMahan, Archacologist

C.W. Mishler, Historian

D.R. Reger, Archaeologist

Computer Scrvices

N.W. Crosby, Operations research analyst ${ }^{2}$

D.1. Anctil, Analyst programmer

G.J. Finch, Data processing clerk

.13.S. Hurtik, Analyst programmer

F.L. Jenks, Data processing manager

J.D. Jurgens, Analyst programmer

Fingincering Geology

R.G. Updike, Geologist 2

R. A. Combellick, Geologist

J.N. Davies, Geologist

K.1. Krause, Geologist

I.W. Reeder, Geologist

C.A. Wery, Geological assistant

Geologic Mapping

S.E. Kawlinson, Geologist 2

D.D. Adams, Geological assistant

.J.F. Decker, Geologist

.1.T Dillon, Geologist

D.R. Hickmott, Geological assistunt

.J.T. Kline, Geologist

R.R. Reifenstuhl, Geologist

M.S. Robinson, Geologist

1).N. Solie, Geologist

Minerals Investigations

G.H. Pessel, Geologist ${ }^{2}$

M.D. Albanese, Geologist

T.K. Bundtzen, Geologist

L.E. Burns, Geolosist

K.B. Faris, Chemist

'I.A. Bittle, Geological assistant

G.D. March, Geologist

T.F Smith, Geologis

M.A. Wiltse, Chemist
Coal and Peat Investigations

G.K. Fakins, Geologist ${ }^{2}$

.t.G. Clesugh, Geologist

K.M. Goff, Geological assistant

L.I. Lueck, Geologist

R.I). Merritt, Geologist

Oil and Gas Resource Investigations

i).1. Meciee, Geologist ${ }^{2}$

D.L. Bertossa, Geological assistant.

J.J. Hansen, Geophysicist

F.F. Harris, Geological assistant

M.W. Henning, Geologist

.S.A. Nacques, Cartographer

R.W. Kornbrath, Geologist

D.I. Krouskop, Geophy sicist

W.M. Lyle, Geologist

J.F. Meyer, Geophysicist

C.G. Mull, Geologist

M.F. Pritchard, Cartographer

T.N. Smith, Geologist

S.M. Weum, Geophysicist

B.K. Wilson, Geological assistant

Resource Allocation Services

D.F. Jones, Geologist ${ }^{2}$

F. F. Becia, Natural resource manager

M.S. Christy, Geologist

G.A. Dickison, Natural resource manager

T.G. Jehnson, Data control specialjst

.J. Tam, Natural resource officer

M.J. Wibbenmeyer, Natural resource manager

Resource Information

C.1. Daniels, Publications specialist ${ }^{2}$

K.H, Clautice, Geologist

B.A. Harte, Cartographer

G.M. Laird, Cartographer

R.1. Mann, Clerk

K. F. Ohlund, Clerk ty pist

K.s. pearson, Cartographer

V.l. Reger, Publications technician

J.S. Sapp, Clerk ty pist

L.C. Schell, Cartographer

Water Resouree Investigations

W.F. Long, IIydrolosist ${ }^{2}$

R.1). Allely, Hydrologist

S.J. Carrick, Hy drologist

F.J. Collazzi, Hydrologist

1.1. Dearborn, Hydrologist

.M.G. Inghram, Hydrologist

R.W. Ireland, Hydrologist

S.F, Mack, Hydrologist

M.A. Maurer, Hydrologist

J.L. Maynard, Hydrologist

M.A. Moorman, Geologist

I. A Munter, Hydrologist

W.A. Petrick, Hydrologist

Geothermal Investigations

.. .J. Motyka, Geologist ${ }^{2}$

S.A. Liss, Geological assistant

C.A. Nye, Geolonist

\footnotetext{
${ }^{1}$ In addition to the permanent staff listed above, DGGS has employed over 100 students in the Department of Natural Resources student Intern Program.
}

2 Section Chief. 